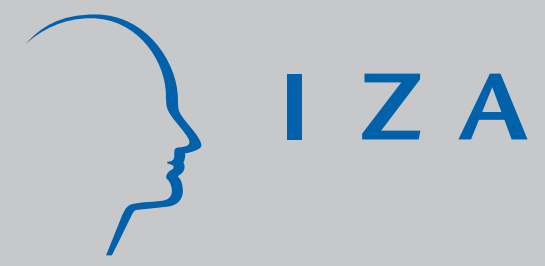

IZA DP No. 7898

The Short- and Long-Term Effects of School Choice on Student Outcomes:

Evidence from a School Choice Reform in Sweden

Verena Wondratschek

Karin Edmark

Markus Frölich

January 2014 


\title{
The Short- and Long-Term Effects of School Choice on Student Outcomes: Evidence from a School Choice Reform in Sweden
}

\author{
Verena Wondratschek \\ Centre for European Economic Research (ZEW) \\ and IFN \\ Karin Edmark \\ Research Institute of Industrial Economics (IFN), \\ CESIfo, IFAU, UCLS and UCFS \\ Markus Frölich \\ University of Mannheim, \\ IFAU, IZA and ZEW
}

\author{
Discussion Paper No. 7898 \\ January 2014
}

IZA

P.O. Box 7240

53072 Bonn

Germany

Phone: +49-228-3894-0

Fax: +49-228-3894-180

E-mail: iza@iza.org

Any opinions expressed here are those of the author(s) and not those of IZA. Research published in this series may include views on policy, but the institute itself takes no institutional policy positions. The IZA research network is committed to the IZA Guiding Principles of Research Integrity.

The Institute for the Study of Labor (IZA) in Bonn is a local and virtual international research center and a place of communication between science, politics and business. IZA is an independent nonprofit organization supported by Deutsche Post Foundation. The center is associated with the University of Bonn and offers a stimulating research environment through its international network, workshops and conferences, data service, project support, research visits and doctoral program. IZA engages in (i) original and internationally competitive research in all fields of labor economics, (ii) development of policy concepts, and (iii) dissemination of research results and concepts to the interested public.

IZA Discussion Papers often represent preliminary work and are circulated to encourage discussion. Citation of such a paper should account for its provisional character. A revised version may be available directly from the author. 


\section{ABSTRACT}

\section{The Short- and Long-Term Effects of School Choice on Student Outcomes: Evidence from a School Choice Reform in Sweden}

This paper evaluates the effects of a major Swedish school choice reform. The reform in 1992 increased school choice and competition among public schools as well as through a large-scale introduction of private schools. We estimate the effects of school choice and competition, using precise geographical information on the locations of school buildings and children's homes for the entire Swedish population for several cohorts affected at different stages in their educational career. We can measure the long-term effects up to age 25 . We find that increased school choice had very small, but positive, effects on marks at the end of compulsory schooling, but virtually zero effects on longer term outcomes such as university education, employment, criminal activity and health.

JEL Classification: $\quad$ 120, C21

Keywords: school choice, school competition, treatment evaluation, cognitive and non-cognitive skills

Corresponding author:

Markus Frölich

Chair of Econometrics

Universität Mannheim

L7, 3-5

68131 Mannheim

Germany

E-mail: froelich@uni-mannheim.de

\footnotetext{
"We thank Louise Johannesson, Lennart Ziegler and Nina Öhrn for excellent research assistance. We also thank Mikael Lindahl, Anders Böhlmark, Jonas Vlachos, Peter Fredriksson, Helena Holmlund, Caroline Hall and seminar participants at IFAU, IFN, ZEW University of Mannheim, the HECER Economics of Education Summer Meeting and the SOLE 2013 Meeting, for valuable comments. We gratefully acknowledge project funding from The Swedish Research Council. The first author would furthermore like to thank IFAU and IFN for kindly hosting her as guest researcher on several occasions. The first author gratefully acknowledges support from the Leibniz Association, Bonn, in the research network "Non-Cognitive Skills: Acquisition and Economic Consequences". The second author is grateful for financial support from the Jan Wallander and Tom Hedelius foundation. The third author acknowledges support from the Research Center (SFB) 884 "Political Economy of Reforms" Project B5, funded by the German Research Foundation (DFG).
} 


\section{Introduction}

Whether or not students should be allowed to choose their school of attendance is a highly controversial topic in many countries. Whereas some see school choice as a means to improve students' results, others fear that choice and competition will have adverse effects on the school system. Economic theory has no clear predictions on this matter: the aggregate expected effects of school choice and competition on students' outcomes are ambiguous. Empirical evaluations of existing school choice reforms are therefore important as they provide information on the actual effects of school choice policies.

In this paper ${ }^{1}$ we evaluate the effects of a large-scale school choice reform in Sweden on student outcomes. The reform was implemented in 1992 and has significantly increased the amount of school choice in compulsory education. It essentially contained two elements: first, it allowed publicly funded but privately run schools2 to set up and compete on basically equal terms with the publicly run schools; second, it encouraged choice among the already existing public schools. We believe that this reform, together with the detailed data that we have access to, provides a good opportunity for obtaining empirical evidence on the effects of a school choice reform. Moreover, since the reform was introduced 20 years ago, we can now assess not only its short-term but also its long-term effects.

The first part of the reform, the introduction of privately run, but publicly funded, schools, has been extensively studied. ${ }^{3}$ The overall evidence of the previous studies suggests that competition and choice, in terms of a higher share of students in the municipality attending private schools, has had positive and, depending on the identification strategy and definition of outcome, modest to large effects. There is also a vast international literature on the effects of school choice and competition on student

\footnotetext{
${ }^{1}$ A compressed version of this working paper is forthcoming in Annals of Economics and Statistics. This working paper is a more extensive version of the journal article, with some additional details and analysis.

${ }^{2}$ The Swedish term is friskolor, i .e. "independent schools", but we will refer to them as private schools throughout the paper.

${ }^{3}$ See Ahlin (2003), Sandström and Bergström (2005), Björklund, Edin, Fredriksson and Krueger (2004), Böhlmark and Lindahl (2007) and (2012), and Hensvik (2012).
} 
outcomes. As the context in which choice and competition takes place differs between studies (i.e. whether choice options are among public, private, faith and/or charter schools, whether schools can select students on the basis of ability, background or other characteristics) and the effect identified by the studies differs (i.e. the effect on those who changed a school after receiving the option only, or the effect on the whole student population), the results vary from being insignificantly different from zero to being relatively large and positive. ${ }^{4}$

Our study adds to the international literature by providing evidence on the effects of a large-scale voucher reform concerning both public and private schools, and by studying not only short-run outcomes, such as marks, but also long-run outcomes, such as labour market and social outcomes. Moreover, it differs from the previous Swedish studies in several ways. First, while previous studies focused on the effects of private schools, we study the overall effects of the choice reform, including in particular the choice among public schools. The latter could be particularly important since choice between public schools could be exerted immediately after the reform, whereas choice among private schools naturally requires that such new schools be founded, something that may take time and may not happen in all parts of the country. In fact, according to the National Board of Education, even in school year 2004/05, private schools existed only in 166 out of the 290 municipalities, and survey evidence suggests that, in school year 2000/01, choosing another public school than the nearest one was more common than choosing a private school. ${ }^{5}$

Second, whereas the previous studies evaluate the effects of private schools measured by their share of students at the level of the municipality, we use detailed geographical information on the locations of schools and student residences to construct measures of choice, reflecting the number of schools near home that are specific for

\footnotetext{
${ }^{4}$ Bettinger (2011) presents a recent review on effects of voucher reforms. Concerning choice among public schools, see for example Hoxby (2000a, 2007) for an influential study showing positive effects of school competition in the US on test scores. This study has been criticized by Rothstein (2007) who argues that the results turn insignificant after a few changes to the empirical analysis. Gibbons, Machin \& Silva (2008) analyze the education market in the UK, making use of the distance to nearby schools as we do in this study, and find no effect of competition or choice for community schools but small positive effects for faith schools. Hsieh \& Urquiola (2006) present evidence from a voucher reform in Chile, finding no average positive effects on outcomes but only increased sorting in private schools (which is related to the design of the admission rules of the private schools).

${ }^{5}$ See the National Board of Education, 2005, p.29 and The National Board of Education, 2003, pp. 48f.
} 
each student. Our evaluation method then consists of comparing the outcomes of students with different degrees of school choice who were in compulsory education before versus after the reform. The idea is that students with few schools nearby will in practice be less affected by the introduction of the choice reforms (i.e. they will only have one school to choose from anyway), while for students with many schools nearby, the choice reforms will have a large impact on the actual choice opportunities ${ }^{6}$.

Using identifying variation at the student-level, instead of at the level of the municipality, is potentially important since municipalities vary a lot in size, both in terms of population and area, ${ }^{7}$ which means that variation only across municipalities may be too crude to capture the essential variation in choice. Our approach also has the advantage of estimating the effects of choice opportunities, whereas the share of students in private schools only measures the degree to which students exercised choice to private schools. This is a possibly important distinction, as (potential) choice could affect school quality via competition effects among schools, even if we only observe few individuals to actually change their school of attendance.

An important methodological issue that we need to deal with is the fact that the location of schools after the reform, in particular of the private schools, is likely to be endogenous with respect to student and community factors (such as student ability and background, or population density), or with respect to the performance of existing schools in the area (demand for private schools could for example be higher where public schools are bad). Moreover, if school choice and the resulting competition leads to improved school quality, it might also be that parents who are very concerned about education may move to regions with many schools. ${ }^{8}$ If we knew which factors were important, we could control for them; yet, several factors may be unobserved.

Our empirical strategy to deal with this is to use the pre-reform locations of schools and students' homes to measure choice. That is, for students choosing a school in or

\footnotetext{
${ }^{6}$ Note that there may still be an effect on students that only have one school nearby, as already the threat of a new school opening up in the area might increase the educational quality of the existing school.

${ }^{7}$ The largest municipality in terms of population, Stockholm, had 864,324 inhabitants in 2011, while the smallest, Bjurholm, had 2,431. The largest municipality in terms of area, Kiruna, is $20715 \mathrm{~km}^{2}$ and the smallest, Sundbyberg, is $9 \mathrm{~km}^{2}$. (Source: www.scb.se)

${ }^{8}$ Before the reform, we would see parents move as close as possible to a good school, irrespective of whether there were many other schools in the area.
} 
after autumn 1992, we will use the locations (of schools and individuals) right before the reform, in 1991. As we argue later, the school choice reform came largely as a surprise because of an unexpected national election outcome. Hence, the location of schools and families was pre-determined to the reform.

Using the pre-reform measures for choice implies that our estimates capture how the effect of the school choice reform differs between students with varying degrees of potential choice (in terms of number of schools nearby) available at the outset of the reform. The estimates can hence be characterised as "intention-to-treat"-effects of the reform. They will include all effects resulting from the dynamic processes that were triggered by the choice opportunities at the outset of the reform, like the opening or closing of schools and parents moving in response to the new options. In additional analyses we will also examine these processes.

Obviously, the location of schools even before 1992 was not random and in addition school choice was possible to some extent by moving residence (i.e. Tiebout choice, see Tiebout, 1956). To deal with this, we control for many observable background characteristics at the individual and regional level and include municipality fixed effects. Since our data contain also unaffected cohorts, we can in addition control for all time-constant relationships between having many schools nearby and student outcomes, and we can test whether pseudo treatment effects are indeed zero and control for prereform trends.

We draw on very informative register data on the entire population of students and schools in Sweden, including a broad range of short term and long term student outcomes, ranging from educational results to labour market outcomes and socioeconomic indicators. The data cover a long period and hence enable us to evaluate the effects both immediately after the reform and many years later. This is important since effects on non-cognitive skills may not be fully reflected in school results but may become visible only later in labour market outcomes or criminal activity.

Our empirical results reveal that the effects of school choice were small during the period considered. This finding applies to the short-term effects on test scores and grades as well as to the longer-term effects on employment, higher education, criminal activity and health, where there is often no, or no economically relevant, effect. The 
effects become larger for younger cohorts, i.e. those affected by the reform earlier in life, yet remain small.

The fact that the largest effects are obtained when we use grades as the outcome variable, suggests that the effects may be driven by grade inflation. However, we can to some extent test for grade inflation, and our test suggests that grade inflation is unlikely to explain all of the effect. In any case, it can be emphasized that irrespective of whether grade inflation partly explains the result or not, the effect that we measure is small.

A potential explanation for the small effects of the choice reform that are measured in this paper, is that the previously existing Tiebout choice (i.e. moving homes) may already have provided sufficient choice options for those families who wanted to choose. Moreover, according to economic theory, the school choice reform is expected to affect students' outcomes in various ways, and it is possible that the very small estimated effects reflect that negative and positive effects in practice cancel each other out.

\section{The Swedish School System}

\subsection{General information on the Swedish school system}

Sweden has nine years of compulsory schooling, starting from the year the student turns seven. During these grades all students follow the same basic curriculum. After the compulsory schooling, the great majority of students continue to voluntary secondary school. ${ }^{9}$

Compulsory education is organized in three stages: grades 1 to 3, grades 4 to 6 and finally grades 7 to 9 . Grades 1 to 6 are referred to as primary school, whereas secondary school starts with grade 7 . Schools usually offer either only grades 1 to 6 , or grades 7 to 9, while some offer all grades 1 to 9 . Therefore, school choice is particularly relevant for entering school (i.e. grade 1) but also for grade 7, where many students graduate from elementary schools offering only grades 1 to 6 .

\footnotetext{
${ }^{9}$ In 2011, 98 percent of students entered secondary school. The share of students graduating from secondary school in at most 4 years was approximately 75 percent in years 1999-2011 (see The National Board of Education: www.skolverket.se).
} 
Compulsory education is organized and provided by the municipalities, and the main source of finance of compulsory education is municipal tax revenues, followed by central government grants. Both the tax base and the grants are adjusted by equalization formulas that are designed to give municipalities with different population structures roughly equal economic conditions.

\subsection{The school system before the reform in 1992}

The school choice reforms that are studied in this paper took place in the early 1990s. Before that, school choice in Sweden was very limited, as students were placed in the school of their catchment area. Privately run schools existed, but they were few, and public funds were restricted to schools with alternative pedagogic profiles. ${ }^{10}$ There also existed a few public schools with special profiles, such as music, that accepted students based on their skills in the relevant subject. In general, however, school choice was limited to Tiebout-choice; i.e. to moving near the desired school. ${ }^{11}$

Politically, there were however heated debates on choice and competition in the public sector, including the education system. The right-wing opposition, especially the party Moderaterna, argued in favor of increased school choice and competition throughout the 1980s, but the Social Democrats, who were in power for most of the decade, had a much more restrictive attitude. This reluctance started to soften during the late years of the 1980s, but even then the idea of the Social Democrats was first and foremost to increase choice and flexibility by increasing the local influence within schools, for example in terms of allowing schools to profile in terms of pedagogical style or special subjects. ${ }^{12}$ It can be noted that school choice was tentatively discussed also by the Social Democrats in the late 80s and early 90s, but then mainly in terms of making it easier to choose schools with special profiles, should these become more

\footnotetext{
${ }^{10}$ In fact, until 1987, in order to receive public funding, schools were in addition required to prove that the use of these alternative pedagogical methods also benefited the development of the public schools, see The National Board of Education (2003)

${ }^{11}$ The allocation of students to schools was regulated in the compulsory school decree (Grundskoleförordningen 1988:655 Chapter $2 \S 23$ ), where it was stated that the allocation shall be based on what is appropriate in terms of transportation, efficient usage of facilities and other educational resources, and on parents' and students' wishes. While the regulation hence specified parents' and students' wishes as one (out of many) factor(s) to be considered, the general rule was that students were allocated to the nearest school.

${ }^{12}$ See for example prop 1988/89:4.
} 
common. ${ }^{13}$ Apart from the few existing private schools and schools with special profiles, school choice only existed at the idea stage. This was however soon to change.

\subsection{The 1990s school choice reforms}

The regime shift in terms of school choice began in the fall of 1991, after a very tight parliamentary election brought a right wing coalition to power. ${ }^{14}$ The newly elected government took a series of steps to increase choice and competition in the education sector:

In March 1992, the government proclaimed, in proposition 1991/92:95, that the aim was to "achieve the largest possible freedom for children and parents to choose school”. It furthermore stated that "This freedom should apply both to choice between the existing public municipal schools, and to private schools.” ${ }^{15}$

In June 1992, the parliament voted in favour of the proposition, and thus opened up for more choice between the existing public schools as well as for publicly funded but privately run compulsory schools to operate under basically the same conditions as the public schools. This new type of privately run school was to receive funding, through a voucher system, from the enrolled students' home municipalities, at a minimum of $85 \%$ of the average cost per student in the home municipality. ${ }^{16}$ The schools were to be open to all students, and could only charge very limited additional student fees.

In 1994, another change in the school law, following proposition 1992/93:230, opened up for choosing a public school in another municipality than that of residence,

\footnotetext{
${ }^{13}$ See pp. 56-57 prop 1988/89:4.

${ }^{14}$ The right wing coalition (Moderaterna; Folkpartiet; Centerpartiet; and Kristdemokraterna) obtained 46.6\% of votes, the socialist block (The Social Democrats and the Left Party (Vänsterpartiet)) 42.2\%, and a populist party, New Democracy, which has since then disappeared from politics, obtained $6.7 \%$ and hence acquired a power balancing position. The greens, Miljöpartiet, received $3.7 \%$ of the votes and were hence only $0.3 \%$ from parliamentary representation, which requires passing the 4 percent threshold. In 1994 the Social Democrats came back to power, but by then the school choice reform was largely accepted, and no attempts were made to reverse it.

${ }^{15}$ See proposition 1991/92:95: ”Målet är att åstadkomma största möjliga frihet för barn och föräldrar att välja skola. Denna frihet bör innebära möjlighet att välja mellan det offentliga skolväsendet och fristående skolor men också att välja skola inom det kommunala skolväsendet och att välja också en skola i annan kommun.”

${ }^{16}$ The reason for setting the minimum compensation level to less than $100 \%$ of the public schools' average cost reflected that the public schools were still ultimately responsible for granting all students in the municipality compulsory education. This, it was argued, could give rise to higher costs for example for administrative costs for ensuring that all students in the municipality attend school and costs from having to offer schooling to children from private schools that stop operating. In addition, public schools have to cater to all students, and cannot select students by for example offering only certain profiles (see prop 1991/92:95.) In1994, following the return of the Social Democrats to power, the minimum voucher level was lowered to $75 \%$ of the average cost.
} 
something that was previously only allowed for independent schools, or in special cases such as bullying. ${ }^{17}$

In summary, propositions 1991/92:95 and 1992/93:230 established private schools as a publicly funded alternative, and made a strong statement that the central government viewed school choice as important. While the main law changes implemented in these reforms treated the opening up for independent schools, it is clear from the propositions that the aim was to increase overall school choice, both by facilitating for privately run schools to enter, and by encouraging choice between existing publicly run schools. Evidence by the National Board of Education suggests that school choice, both to private and public schools, has increased a lot during the 20 years that the reform has been in place, in particular in more urban areas. ${ }^{18}$

\subsection{Other education-related reforms}

The school choice reforms in the early 1990s were not the only education-related changes taking place in the 1990s, but they were part of a broad decentralization and choice-enhancing trend in the organization of the educational sector, as well as in the public sector in general. The main changes consisted of making the municipalities, instead of the central government, responsible for the provision and organization of compulsory education, and of replacing the system of ear-marked central government grants with a system of general central government grants. ${ }^{19}$ Since these other reforms increased the municipalities' influence over compulsory education, it is reassuring that our analysis is, in contrast to most other studies of the Swedish choice reform, not conducted at the level of the municipality, which would risk to pick up effects of these other reforms.

\footnotetext{
${ }^{17}$ Following this proposition, the independent school reform was also expanded to secondary school level (grades 10$12)$.

${ }^{18}$ See Section 0 in the Appendix.

${ }^{19}$ For a more detailed overview of these reforms, see Section 0 in the Appendix.
} 


\section{Mechanisms of School Choice}

In pre-reform Sweden, students were in general allocated to schools according to the proximity principle (i.e. to the nearest school), and the only way to change school was by moving. With the reform, choice could be exercised without moving. These enhanced choice options could affect student outcomes through various channels.

First, school choice can improve the matching of students and schools, e.g. regarding the desired pedagogical tools or any other aspect of the student-school match that improves the productivity of education. This should have an unambiguously positive effect on student and school results. In addition students may increase their effort if they are allowed to attend the school of their liking.

Second, school choice may affect the allocation of students, which in turn gives rise to different peer effects. ${ }^{20}$ Theoretically, it is not clear how school choice should affect the composition of students between schools: On the one hand, loosening the link between residential address and school of attendance could in principle decrease segregation ${ }^{21}$ with respect to parental background (income, immigrant background etc), as students are no longer required to attend the school nearest to their home. That is, students from poorer areas can gain access to schools in rich areas, even though they cannot afford to live there. On the other hand, however, school choice can also lead to more segregation, if parents/students increasingly choose to attend schools with similar peers.

It is also a priori unclear how being surrounded by more or less similar peers (with respect to academic ability, parental background etc) may affect students' educational outcomes. On the one hand, more homogenous classes are easier to teach. On the other hand, weaker students may benefit disproportionally from stronger students, which are only available in more heterogeneous classes. The overall effects are ambiguous.

\footnotetext{
${ }^{20}$ See for example Epple and Romano (1998) for a theoretical model on school choice where students sort according to ability and where peer effects are modelled. For empirical evidence on peer effects, see for example Zimmerman (2003), Sacerdote (2001), Lefgren (2004), Hanushek et al. (2002), Angrist and Lang (2004), Ammermueller and Pischke (2009), Lavy and Schlosser (2007) and Hoxby (2000b).

${ }^{21}$ Segregation may refer to different aspects of student and parental characteristics. Here we deliberately use the term loosely, in the sense of "less mixing" with respect to any characteristic that may be of importance for peer effects and so to the productivity of education.
} 
Third, school choice can put competitive pressure on schools to improve quality in order to attract students. ${ }^{22}$ That more competition leads to higher quality however hinges on a couple of assumptions: i) that school quality is a determining factor for the choice of school; ii) that parents can observe school quality; iii) that schools have an incentive to attract students. The fact that funding for Swedish schools is, at least partly, based on the number of students, ${ }^{23}$ suggests that there is an incentive for schools to at least attract enough students to fill the classes, in order to cover the fixed costs for facilities and teachers. Having many applicants may in addition be desirable as it signals high reputation and status, and teachers and headmasters have a clear incentive to avoid a situation where the number of students is so low that the school is forced to shut down.

The first assumption - that school choice is based on the quality of the school - is complicated by the fact that school quality can be difficult to observe. This means that, even though parents, all else equal, may want to choose the better school, they may in practise not be able to observe this. In the Swedish case, this is a relevant aspect, since the only school level results that are publicly available are the final average grades, i.e. grades when students exit compulsory school in grade 9. In addition, if school choice is determined by student grades, schools have an incentive to inflate grades, which naturally devaluates their value as quality indicators. ${ }^{24}$

\footnotetext{
${ }^{22}$ See Hoxby (2003) on school choice and school quality. See also Hanushek (1986) for an early overview of education production functions.

${ }^{23}$ There exists little information on the different resource allocation models used by the municipalities: the first country wide survey, covering all municipalities, refers to the situation in 2007 (The National Board of Education (2009)). The survey suggests that the vast majority of municipalities base the resource allocation on the number of students (although part of the budget is not per-student-based, but based on for example special needs). Only 9 percent of the municipalities responded that none of the budget was directly volume based, and that the allocation was instead made through an application-procedure (the Swedish term is: äskanden), and through dialogue with the school units. According to the authors of the report, it is however likely that volume was indirectly considered also in these municipalities, although not necessarily through an exact amount per student (p. 39). The survey furthermore suggests that the budget allocation procedures have often been in place for a long time: 52 percent of the municipalities respond that they have used the same model for the last six budget years or more. 22 percent respond that the current model has been used for 4-5 budget years, and the remaining 26 percent respond that the current model has been used for less than four budget years.

${ }^{24}$ Vlachos (2010) suggests that the competition stemming from the introduction of independent schools has given rise to some, but very modest, grade inflation. His estimations suggest that a ten percentage point increase in the private school-share would give rise to a 1-2 unit increase in the average student credit values (which is a measure of students GPA). This is a small effect, considering that student credit values are given at a 0-320 scale, with mean value at 206. We examine grade inflation in Section 0. in the Appendix.
} 
In addition, there are a number of factors - apart from school results - that potentially influence the choice of school, such as proximity, facilities, peers, extracurricular activities etc. ${ }^{25}$ These factors may or may not be correlated with students' learning. The competitive pressure on schools to attract students can hence in principle even give rise to negative effects on student outcomes by shifting focus from factors that improve teaching and learning to factors that are unrelated to students' learning, but potentially more easily observable, such as peer quality.

In sum, school choice can in theory give rise to various mechanisms, and it is hence a priori unclear which effects we should expect on students' outcomes. To be more concrete, school choice could, through these various mechanisms, potentially affect not only academic results, but also social outcomes. For example the likelihood to commit crime is likely to be affected by the peer group. Effects both on the individuals' educational attainment and on her social capital, can in addition affect longer term outcomes such as further education, labor market success or health. This motivates our choice to study not only short term educational outcomes, but also longer term, and social, outcomes.

It is also worth mentioning that the Swedish school choice reforms are likely to give rise to a process of changing incentives: For example, even if competition between schools eventually gives rise to over-all higher quality, this is a process that is likely to take time, and that may in the meantime cause disruptions, as bad schools downsize and better performing schools expand. The effects of the school choice reform may hence take time, and may also look different over time. This is important to take into account in the empirical analysis.

\footnotetext{
${ }^{25}$ For example, Burgess et al. (2009) suggest that British families choosing school care both about the academic performance and the student composition.
} 


\section{Data}

\subsection{Data sources and definition of outcomes and covariates}

The study uses Swedish register data for the full population born in the years 1972 to 1990, and contains data from Statistics Sweden, the Swedish National Council for Crime Prevention, the Military Archives and the Swedish Defence Recruitment Agency.

First, as previously mentioned, we have access to detailed information on the geographical location of schools (for years 1988-2006) and students' residences (for 1985-2006), which enable us to construct student level indicators of choice. ${ }^{26}$ How these are constructed will be explained in the following section.

Second, our data contain information on a broad set of short-term and long-term student outcomes: First, we can observe the educational attainment at age 16 in the form of average final grades from compulsory school, i.e. by the end of grade 9 and, for the last 4 cohorts in our sample, the $9^{\text {th }}$ grade test scores in English, Swedish and Math. Since the latter are only available for a subsample of students, we will not make use of the information on the $9^{\text {th }}$ grade test scores in the main analysis, but only in order to test for grade inflation in Section 0 in the Appendix. In addition, for the male students, we have access to cognitive ability test scores from the military draft. These test scores, which are also used in for example Grönqvist et al. (2010) and Lindqvist and Vestman (2011), contain the overall scores from four subtests that measure the draftees verbal, logical, spatial and technical ability, and are used to sort draftees to different assignments in the military service. The draft test scores are available for all cohorts although for the later cohorts, the share of draftees drops significantly. ${ }^{27}$ In terms of longer-term outcomes, we observe whether the individual was employed at the age of 25, as well as the highest educational degree the individual had completed at that age. We choose this age since it allows us to include many cohorts in the analysis - choosing a later age would have the benefits of capturing also older graduates, but would on the

\footnotetext{
${ }^{26}$ Specifically, we have access to the midpoint coordinate of $100 * 100 \mathrm{~m}$ squares for student residence and school location, i.e. the coordinates measure the residential location with a maximum error of approximately 70 meters.

${ }^{27}$ Until the late 90 s, virtually all 18 year old males were required to take the test. After that, although the universal draft remains on paper, in practise only a minority of each cohort goes through the military service, see Figure 5 in the Appendix. According to anecdotal evidence the drafting decision can now in practise be influenced by the draftees, which leads to potential selection problems in this variable. We have analysed whether the selection is related to the choice reform (see Section 0 in Appendix), but find only a very small association, that we do not believe to have important effects for our results.
} 
other hand decrease the number of cohorts for which we observe the outcome. We also observe whether individuals had health problems, indicated by receiving sickness benefits $^{28}$, at age 22, and whether the individual had ever been convicted for crime (including all crimes, from pilfering and petty traffic- and drug related crimes, to more serious types of crime, but excluding civil penalty) ${ }^{29}$ at the same age.

An important task will be to control for all covariates that could potentially influence the outcomes, while also being correlated with the choice variable. We therefore use a broad set of background covariates at the level of the student (including parental background information) as well as at the level of the local area (parish and/or municipality). The list of control variables will be given in the footnote to Table 3 and further descriptive statistics are given in Table 20 in the Appendix.

Table 1 shows descriptive statistics of students' outcomes for affected and nonaffected cohorts. Non-affected cohorts are those that have left $9^{\text {th }}$ grade before autumn 1992, i.e. before the reform was implemented. These are all students born in the years 1972 to 1976. Summary statistics of the choice measure will be given in Section 4.2.

Comparing the development of outcomes for the two different cohort groups we see an increase in the share of individuals with a university degree at age 25 from $35 \%$ to $41 \%$ and a decrease in share of those employed at the same age from $71 \%$ to $69 \%$. It has to be taken into account, of course, that there are also still students that have not yet finished their studies at this age, which might thus reduce the share of employed individuals. The percentile rank in the grade point average at grade 9, which ranges from 0 to 100, has a mean of 48.21 for the non-treated and 49.40 for the treated cohorts, and a standard deviation of 28.6 for both. ${ }^{30}$ The cognitive score is a standardized measure that ranges between one and nine, with median value 5 , and has a mean of around 5 and a standard deviation of about 1.9 in both cohort groups. The share of those having committed any criminal offense up until age 22 is $16 \%$ for the untreated and $14 \%$ for the treated cohorts. Note that this includes also includes small offenses, like

\footnotetext{
${ }^{28}$ This variable is based on the sum of the yearly benefits received as sickness benefits and as benefits for early retirement due to bad health. We define an individual as having health problems if she/he received an amount exceeding the price base amount, which is an amount used in the social welfare legislation, and which varies with the aggregate price level. During the data period of our study, this amount was approximately €4,000.

${ }^{29}$ The Swedish term is "ordningsböter".

${ }^{30}$ The reason for the mean rank value not being exactly 50 is that ties in the data were given the same rank.
} 
speeding or petty crimes, which explains why the share is not smaller. Since school choice may affect a student's peer group and the degree of segregation, which in turn could affect the social adjustment of students, we believe that it is important to also include these less serious types of offenses.

Table 1: Descriptive statistics for outcome variables

\begin{tabular}{|c|c|c|c|c|c|c|}
\hline & \multicolumn{3}{|c|}{$\begin{array}{l}\text { PRE'REFORM COHORTS } \\
\text { (cohorts 1972-1976 are not affected) }\end{array}$} & \multicolumn{3}{|c|}{$\begin{array}{l}\text { POST-REFORM COHORTS } \\
\text { (cohorts 1977-1990 are affected) }\end{array}$} \\
\hline & Mean & Std. Dev. & Obs. & Mean & Std. Dev. & Obs. \\
\hline Percentile rank GPA 9 & 48.21 & 28.58 & 437953 & 49.40 & 28.60 & 1277468 \\
\hline Cognitive score & 5.06 & 1.93 & 213145 & 5.04 & 1.94 & 403161 \\
\hline University degree (at age 25 ) & 0.35 & 0.48 & 445295 & 0.41 & 0.49 & 692729 \\
\hline Employed (at age 25) & 0.71 & 0.45 & 446509 & 0.69 & 0.46 & 698068 \\
\hline $\begin{array}{l}\text { Entry in criminal record (until } \\
\text { age } 22 \text { ) }\end{array}$ & 0.16 & 0.36 & 449802 & 0.14 & 0.35 & 990157 \\
\hline Health problem (at age 22) & 0.07 & 0.26 & 448043 & 0.08 & 0.27 & 985478 \\
\hline
\end{tabular}

Note: Sample contains only observations with full information on all covariates X given below Table 3.

\subsection{Measuring the degree of choice among schools}

The degree to which students can exercise school choice crucially depends on the availability of alternative schools in the vicinity of students' homes. Thus, we measure the degree of school choice by exploring the distance between a student's home and the schools a student could potentially choose from. Specifically, we count the number of schools within a given radius around a student's home in order to measure her choice possibilities. ${ }^{31}$ As Sweden is a geographically diverse country with very rural but also urban areas, our preferred radius is the median commuting distance within each municipality in $1992 .^{32}$ This radius takes different local settings into account in a very flexible way and, in our opinion, can be used to approximate the area within which parents might consider different schools for their children. (Note that we measure median commuting distance before the reform.) The average median commuting distance across all municipalities is about $5 \mathrm{~km}$. In addition to this flexible radius, we

\footnotetext{
${ }^{31}$ See for example also Gibbons, Machin and Silva. (2008), Himmler (2009) and Noailly, Vujic and Aouragh (2009) for other studies using the distance between a student's home and schools to measure school choice.

${ }^{32}$ We are grateful to John Östh for providing information on municipality commuting distances. The distances are measured "as the crow flies", and do not take into account the directions of roads etcetera.
} 
will also estimate the effects using a $2 \mathrm{~km}$ radius as a test of the robustness of the results. (We also explored several different other radii and obtained similar empirical results.)

Another issue refers to the point in time in a child's schooling career when one should measure the degree of available school choice. As explained above, in the Swedish compulsory schooling system, it is common not only to choose a school when starting first grade, but to also potentially change school at the beginning of $7^{\text {th }}$, and sometimes also $4^{\text {th }}$, grade. For this reason, there are three points in time in the schooling career at which the degree of school choice might potentially be important. We find that these measures are very highly correlated, i.e. having more schools in the neighbourhood that offer grades 1-3 is highly correlated with also having more schools that offer grades 7-9 nearby. Because of the high correlations, we will only include choice measured at one grade level at a time in the estimations, and following the previous Swedish studies, which all analyse choice and competition in grade 9, we focus on choice opportunities when choosing a school that offers grades 7-9. Note also that this is a point in a child's educational career at which parents might pay special attention to choosing a school, as the marks at the end of $9^{\text {th }}$ grade are important for admission into high school. In our main specification, we thus measure how many schools offering grades 7-9 a child may choose from at the age of 13, which is when children enter $7^{\text {th }}$ grade, or, as will be further explained in section 5 , in 1991, if the child started seventh grade after the reform. However, since we lack geographical information on schools prior to year 1988, students born in the years 1972-1974, who should be matched to schools' location in the years 1985-87, will be matched to schools' location in the year 1988 instead.

Table 2 shows descriptive statistics for our choice measures separately for affected and non-affected cohorts. The average number and the standard deviation of schools offering grades 7-9 within median commuting distance around a student's home are 3.45 and 4.66 for the non-affected cohorts ${ }^{33}$. With a mean of 5.91, students born after 1976 have on average more schools within their median commuting distance, measured at their place of residence in 1991 and taking into account schools existing in 1991 only.

\footnotetext{
${ }^{33}$ The average median commuting distance over all municipalities is $5.8 \mathrm{~km}$, with a standard deviation of $4.2 \mathrm{~km}$, minimum of almost $1 \mathrm{~km}$ and a maximum of $26 \mathrm{~km}$.
} 
The reason for this increase is that our choice-measures take the 1994 law change into account that enabled students to attend public schools also in other municipalities, something which was previously restricted to special cases or private schools. For the smaller radius of $2 \mathrm{~km}$, this change has less impact, and the average number of schools within $2 \mathrm{~km}$ around a student's home only increases from 1.24 to 1.35 schools for affected versus non-affected cohorts.

Table 2: Descriptive statistics for pre-reform choice measures

\begin{tabular}{|c|c|c|c|c|c|c|c|c|}
\hline & \multicolumn{4}{|c|}{$\begin{array}{l}\text { PRE-REFORM COHORTS } \\
\text { (cohorts 1972-1976 are not affected) }\end{array}$} & \multicolumn{4}{|c|}{$\begin{array}{l}\text { POST-REFORM COHORTS } \\
\text { (cohorts 1977-1990 are affected) }\end{array}$} \\
\hline & Mean & Std. Dev. & Median & Obs. & Mean & Std. Dev. & Median & Obs. \\
\hline \multicolumn{9}{|l|}{ School choice } \\
\hline $\begin{array}{l}\text { Number of schools } \\
\text { within median } \\
\text { commuting distance }\end{array}$ & 3.45 & 4.66 & 2 & 449802 & 5.91 & 9.35 & 2 & 1306879 \\
\hline $\begin{array}{l}\text { Number of schools } \\
\text { within } 2 \mathrm{~km}\end{array}$ & 1.24 & 1.50 & 1 & 449802 & 1.35 & 1.69 & 1 & 1306879 \\
\hline
\end{tabular}

Note: The table displays pre-reform measures on grade level 7-9. Sample contains only observations with full information on all covariates $\mathrm{X}$ given below Table 3 .

Another fact to note is that the median number of schools within $2 \mathrm{~km}$ from students' homes is only one, meaning that for at least $50 \%$ of the sample, this measure implies no choice close to home. When using the radius that is endogenous to local circumstances, namely the median commuting distance, the median number of schools is two, thus already capturing some choice also for those in the lower part of the distribution. The measures will thus compare different groups of people and will have a different power in measuring choice in different regions.

Table 21 in the Appendix in addition shows summary statistics for the standard deviation in the choice-measure within municipalities, both for students in all municipalities, and separately for the urban and non-urban municipalities. ${ }^{34}$ As in Table 2 the values for pre- and post-reform cohorts are shown separately. As can be seen in Table 21, the within-municipality variation is in general large: the within-municipality standard deviation for the commuting-distance based choice measure is 3.4 on average, and around 4 at the median, among both the pre- and the post-reform cohorts ${ }^{35}$. The

\footnotetext{
${ }^{34}$ The definition for urban and non-urban municipality is the same as will be used, and defined, in section 6.3.

${ }^{35}$ This average is calculated over the individuals, not the municipalities.
} 
average within-municipality standard deviation is furthermore much larger for the urban municipalities (larger than 5) than the non-urban municipalities (lower than 1), which is to be expected since the average number of schools is also much larger among the urban municipalities.

We conclude that there is substantial variation in our measure of choice opportunities, both overall and between students within a municipality.

\section{$5 \quad$ Empirical Strategy}

Let us, as a starting point, make the thought experiment that the amount of school choice available to each student was determined by a random experiment. In this case, the effects of the school choice reform could be measured by the $\beta$-coefficient from the following simple regression equation:

$$
Y_{i}=\alpha+\beta c_{i}+u_{i}
$$

where $Y_{i}$ denotes the outcome of student $i, \alpha$ is a constant term, $c_{i}$ is a measure of the amount of school choice available to student $i$, and $u_{i}$ is a random error term.

Now, we know that the distribution of available school choice is unlikely to be random across students, and equation (1) is hence probably inadequate to measure the effects of school choice. In order to estimate the causal effect of school choice as introduced by the 1992 reform, we need to adjust the specification to address a set of challenges. The first is to separate the effect of having more school choice due to the reform from effects of other factors that are related to our choice measure. The second is the potential endogeneity of schools' choice of location and parents' choice of residence after the reform.

Let us start by discussing the first, i.e. to separate the effect of school choice from other factors that are correlated with living in an area with many schools. Our main strategy to deal with this is to pool the observations from all cohorts, both pre- and postreform, and define the reform effect as the differential effect of our choice-indicator for affected and unaffected cohorts. Thus, we estimate the additional effect of having more schools nearby for cohorts that went to school after the reform was implemented, compared to cohorts that went to school before the reform. This allows us to control for 
time-invariant influences of unobserved factors that are correlated with both the choice measure and the outcome variable. In addition, we include many regional- and individual-level covariates to our estimation, to control for observable factors, as well as municipality and cohort fixed effects. These additions result in the following regression equation:

$$
Y_{i}=\alpha c_{i}+\beta D_{i} c_{i}+\lambda_{\text {municipality }}+\gamma_{\text {cohort }}+\delta X_{i}+u_{i}
$$

where, as before, $Y_{i}$ denotes the outcome of student $i, c_{i}$ is the choice measure, and $u_{i}$ is a random error term. Furthermore, $D_{i}$ is an indicator variable for being in compulsory school post-reform, which means that $\beta$ measures the effect of the school choice reform, while $\alpha$ captures the pre-reform correlation between the choice-measure and the outcome, that is, correlation related to having many schools around but unrelated to the actual possibility to choose a school. Note that we do not assume a causal interpretation for the pre-reform coefficient $\alpha$. Regional- and individual-level covariates are denoted

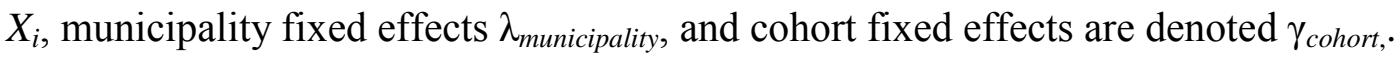

The identifying assumption underlying equation (2) is thus that the effect of having many schools nearby in the counterfactual situation, i.e. if the 1992-reform had never been enacted, can be estimated by the effect of having many schools nearby for cohorts that left compulsory school before the reform was enacted.

This assumption is not directly testable, but we can assess its credibility by performing placebo tests on the five pre-reform student cohorts (i.e. those having left the school system before the reform). That is, we pretend the reform had happened two years earlier and estimate the effect of this "placebo"-reform. In a similar fashion, we can test for time trends in the effect of having more schools nearby in the pre-reform cohorts. Not finding any such placebo-effects or pre-reform trends can be seen as an indication that the results of our analysis are not due to time trends that are unrelated to the choice reform. Finally, even in cases where we do find evidence of time trends before the reform, we can use the five non-affected cohorts of students to estimate and control for such pre-reform time-trends when we estimate the choice-effect of the reform. 
The second empirical challenge that we need to address stems from the location choice of new schools, and the residential choice of parents, after the reform. Many new private schools opened up and their chosen locations are certainly not random. Some of them operate as for-profit schools and would base their location decision on expected profits. Also not-for-profit schools that follow a social mission would not choose geographical location randomly. Ignoring such deliberate location choices in a regression analysis would lead to biased results, where the direction of the bias is uncertain. It could be positive if schools locate in areas where students perform well, e.g. in order to cream skim the best students, or to meet a demand for good schools in areas where parents and students are eager to learn and willing to invest time in actively choosing a school. On the other hand, the bias could be negative if schools locate in areas where the educational quality was previously low.

To deal with these problems, our empirical strategy is to base our measure of choice on the pre-reform location of schools and students. Since the school reform came as a surprise to the population, due to the tight race in the 1991 national election, we can consider them as pre-determined and thus not endogenously affected by the reform itself. Hence, for cohorts that chose a school after 1991, we will approximate the amount of choice they faced by measuring the amount of schools they had nearby in 1991, just before the reform. For cohorts that chose school before the reform, we use students' actual location of residence in the year they enter $7^{\text {th }}$ grade. For the same reason, we will also measure all municipal- and parish-level covariates in 1991 if the choice for grade 7 was taken after 1991. For students who started grade 7 before the reform, we measure all variables at the time when they started grade 7 or, if we do not have data from that year, the most current information.

By measuring choice via the pre-reform location of schools and students, we will measure the overall effect of the reform that goes through having more schools nearby at the beginning of the process. This effect will comprise all dynamic processes happening after the reform, such as new schools opening up or schools closing down, that are related to the initial choice setting. We can hence interpret the identified effect like an intention-to-treat-effect. We believe that our approach captures the policyrelevant parameter, particularly for a school reform that encourages and supports non- 
public schools, such that the exact placement of these schools is more market-driven and less centrally determined.

It is however true that the pre-reform location will not remain a relevant measure forever; in particular for the later cohorts, there is likely to be more measurement error in this variable due to the processes of schools and individuals re-locating. Still, we believe that for the 20-year-period after the reform that we study, our approach provides an interesting method for analysing the effects of the reform. In later sections we will also examine how the school choice reform affected the number of public and private schools, i.e. how our pre-reform measures of school choice are related to school choice measured after the reform.

A further issue to note is that equation (2) estimates the average effect of the school choice reform for all post-reform students. However, as mentioned previously, it is likely that the reform-effect differs between the younger and older affected cohorts. In order to account for this, we could in principle permit the effect of the choice-reform to vary from year to year, i.e. one cohort happened to be in grade five when the reform was enacted, the next cohort was in grade six etc. For statistical precision and also because choice is usually exercised only at grades 1,4 or 7 and rarely at the others, we will instead define treatment windows that capture whether choice could be exercised at grade level 1-3, 4-6 or 7-9, in our main specification. Hence, we define the five dummy variables:

$$
\left(\begin{array}{l}
D_{i}^{1}=1 \text { if born in } 1977 \text { or } 1978 ; \text { zero otherwise } \\
D_{i}^{2}=1 \text { if born in } 1979 \text { or } 1980 \text { or } 1981 ; \text { zero otherwise } \\
D_{i}^{3}=1 \text { if born in } 1982 \text { or } 1983 \text { or } 1984 ; \text { zero otherwise } \\
D_{i}^{4}=1 \text { if born in } 1985 \text { or } 1986 \text { or } 1987 ; \text { zero otherwise } \\
D_{i}^{5}=1 \text { if born in } 1988 \text { or } 1989 \text { or } 1990 ; \text { zero otherwise }
\end{array}\right)
$$

and note that all these treatment dummies are zero for the pre-reform cohorts.

Figure 1 illustrates the grade level at which students belonging to each cohort could potentially have chosen a school, together with the corresponding treatment groups $D^{1}$ to $D^{5}$ that we define. One can see that the first cohort to be possibly affected by the school choice reform at grade level 7-9 is the cohort born in 1977. Even though they 
already went to ninth grade in 1992 and are unlikely to switch school one year before graduation, they might still be affected by the reform through increased competitive pressure on schools. A similar reasoning holds for students from cohort 1978, who started eighth grade in 1992. These two cohorts therefore form no clean control group and are defined to belong to the treatment window $D^{1}$. The first cohort of students to be more likely affected by the new choice options is born in 1979, as they started grade 7 in fall 1992. Only students born before 1977 were not at all affected by the reform.

Figure 1: Treated cohorts

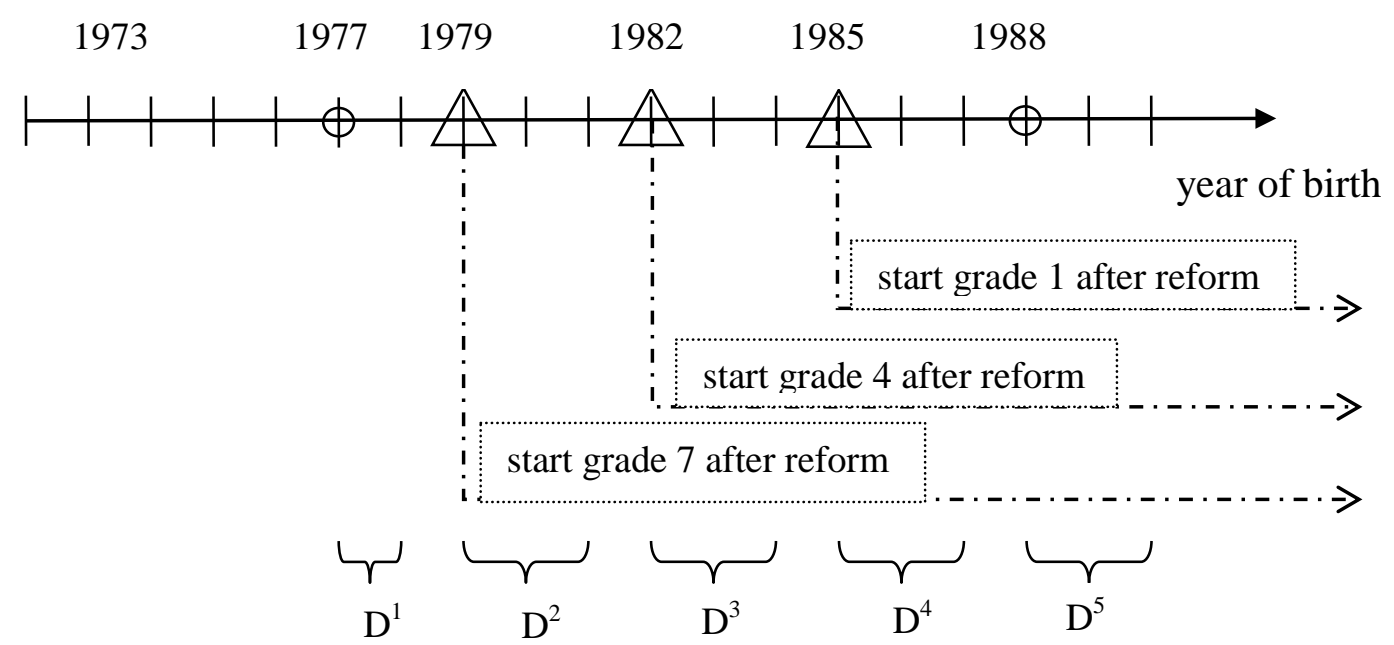

Using these treatment windows, the regression specification that we will estimate is:

(4) $Y_{i}=\alpha c_{i}+\beta_{1} D_{i}^{1} c_{i}+\beta_{2} D_{i}^{2} c_{i}+\beta_{3} D_{i}^{3} c_{i}+\beta_{4} D_{i}^{4} c_{i}+\beta_{5} D_{i}^{5} c_{i}+\lambda_{\text {municipality }}+\gamma_{\text {cohort }}+\delta X_{i}+u_{i}$

In equation (4), the coefficients $\beta_{1}$ to $\beta_{5}$ measure the choice reform effects for the postreform cohorts in the respective treatment windows, while the rest of the notation and interpretation remains as in equation (2). We will estimate equation (4) using OLS for continuous outcomes, and Probit for binary outcomes, and we cluster standard errors at the school level. 


\section{$6 \quad$ Results}

\subsection{Main specifications}

This section presents the estimation results of the regression equations that were described in section 5, and, as previously discussed, the estimates denote the overall effects of the choice reform that work through having more schools nearby at the place of residence right before the reform.

Table 3 shows regression results from estimating equations (2) and (4) for grade level 7-9. These estimates denote the overall effects of the choice reform that work through having more schools nearby at the place of residence right before the reform.

Column 1 shows results from a specification corresponding to equation (2), where a constant treatment effect of the reform is assumed. That is, we compare the average effect of having more schools nearby for cohorts that left primary education before and after 1992. To that end, we interact the number of schools within the median commuting distance of the municipality, denoted "Choice" in the table, with a treatment window indicator that captures all cohorts that were potentially affected by the reform, i.e. all individuals born in or after 1977. The resulting point estimate shows that having one more school within the median commuting distance increases the percentile rank in GPA of cohorts that are affected by the reform by 0.06 . Taking into account the observed variation in the sample ${ }^{36}$, a one standard deviation increase in the choice measure, that is 9.35 more schools, leads to an increase in the percentile rank by about 0.56 . The effect is thus very small.

However, as the reform was enacted only gradually over time, allowing for a timevarying effect is potentially important. The second column of Table 3 therefore shows results from estimating equation (4), with treatment windows as specified in equation system (3). The estimated effect of choice is not significantly different from zero for students born between and in the years 1977 and 1984, but is positive and significant for cohorts 1985-1990, who started first grade after the choice reform was enacted.

\footnotetext{
${ }^{36}$ We use the standard deviation for the post-reform cohorts here.
} 
Table 3: Results from main estimation for percentile rank in marks in grade 9

Outcome: Percentile rank GPA Grade 9

Choice Measure: Number of schools within median commuting distance Grade Level: 7-9

\begin{tabular}{lccc}
\hline & $\begin{array}{c}\text { Constant } \\
\text { treatment effect }\end{array}$ & $\begin{array}{c}\text { Piecewise constant } \\
\text { treatment effect }\end{array}$ & $\begin{array}{c}\text { Placebo treatment } \\
\text { effect }\end{array}$ \\
\hline Choice $\times$ Cohorts 1988-1990 & $0.130^{* * *}$ & $0.125^{* * *}$ \\
Choice $\times$ Cohorts 1985-1987 & $(0.0183)$ & $0.0228)$ \\
& & $0.0772^{* * *}$ & $(0.0229)$ \\
Choice $\times$ Cohorts 1982-1984 & & $(0.0186)$ & 0.00444 \\
& & 0.0100 & $(0.0227)$ \\
Choice $\times$ Cohorts 1979-1981 & & $(0.0183)$ & 0.0175 \\
& & 0.0231 & $(0.0236)$ \\
Choice $\times$ Cohorts 1977-1978 & & $(0.0195)$ & -0.0195 \\
Choice $\times$ Cohorts 1977-1990 & & -0.0139 & $(0.0266)$ \\
Choice & $0.0607 * * *$ & $(0.0227)$ & \\
& $(0.0168)$ & & -0.0280 \\
Placebo test: & -0.0195 & $-0.0334 *$ & $(0.0219)$ \\
Choice $\times$ Cohorts 1975-1976 & $(0.0172)$ & $(0.0173)$ & -0.0107 \\
Constant & & & $(0.0267)$ \\
R-squared & & & $27.01^{* * *}$ \\
\hline
\end{tabular}

Notes: Robust standard errors in parentheses. Statistical significance at 1,5 and 10\% level is denoted by ***, **, *. The definition of the placebo tests is explained in Section 5. The following control variables are included in the estimation:

On the municipality level: population density, taxable income and taxable income squared.

On the parish level: share of Swedish citizens among the 16-64 year old, mean earnings of the 20 to 64 year olds, share of university graduates among the 20 to 64 year olds, share of employed persons among the 20 to 64 year olds, indicator variables for whether the population density of 7-15 year olds is in the lowest or highest quartile across Sweden

On the individual level: household income and household income squared, whether the household received welfare, age of the mother at birth, whether living in a single parent household, number of children in the household, whether child was only child, whether child has Swedish citizenship, indicator variables on mothers and fathers citizenship separately (Swedish, Nordic (=Norwegian, Finnish, Danish), from other western country(=Western Europe, North America, Australia), rest of the world is base category), indicator variables on whether mother and/or father graduated from university or secondary education

Moreover, with an increase in the percentile rank of 0.13 for each additional school within the commuting distance, the effect is largest for the youngest cohorts. It is, however, not increasing in a linear way, which is why we prefer modelling the effect in the piecewise constant fashion rather than with a time trend. In terms of a standard deviation increase in the number of schools within the median commuting distance, the percentile rank in GPA increases on average by 1.2 for cohorts born between 1988 and 
1990, and by 0.7 for cohorts born between 1985 and 1987. Thus, the effect of having more schools nearby on the marks in $9^{\text {th }}$ grade is modest also for these later cohorts.

It can be noted that excluding the set of individual- parish- and municipality-level covariates does not qualitatively affect the results: as is shown in Table 22 in the Appendix the marginal effects change a bit but are not substantially affected. The third column of Table 3 depicts the results from performing a placebo test, in which we pretend that the reform was enacted two years earlier. That is, we generate another treatment window variable that is one for the truly untreated cohorts 1975-1976. The effect on the interaction of this placebo dummy and the choice variable is not statistically different from zero. There is hence no indication of any remaining timevarying correlation between the outcome variable and our choice measure during the pre-reform period, conditional on the included covariates. This is confirmed when estimating Equation (5) and thus allowing for a linear pre-reform trend in the choice effect: the coefficient for this pre-reform trend is again not statistically significant. These results are reassuring concerning the identifying assumption of common-trends in the outcome between groups with low and high values of choice.

Table 4 shows results for the effect of choice on later outcomes, using the treatment window specification corresponding to Equation (4). Column one repeats the results for the percentile rank in order to ease comparability. The military test score in column two is a continuous outcome that varies between one and nine. All other outcomes are binary and denote the probability of a certain outcome being true. The table shows coefficients and clustered standard errors for the cognitive score, and marginal effects at the mean and corresponding standard errors for all other outcomes. 
Table 4: Results for later outcomes

\begin{tabular}{|c|c|c|c|c|c|c|}
\hline & $\begin{array}{l}\text { Percentile } \\
\text { Rank } \\
\text { Grade } 9\end{array}$ & $\begin{array}{l}\text { Cognitive } \\
\text { Draft Score } \\
\text { (Men only) }\end{array}$ & $\begin{array}{l}\text { University } \\
\text { Degree } \\
\text { at Age } 25^{\dagger}\end{array}$ & $\begin{array}{l}\text { Employed } \\
\text { Age } 25\end{array}$ & $\begin{array}{l}\text { Any Crime } \\
\text { until Age } 22\end{array}$ & $\begin{array}{l}\text { Health } \\
\text { Age } 22\end{array}$ \\
\hline $\begin{array}{l}\text { Cohorts } 1988-1990 \\
\text { rel. to untreated }\end{array}$ & $\begin{array}{l}0.130 * * * \\
(0.0183)\end{array}$ & & & & & \\
\hline $\begin{array}{l}\text { Cohorts } 1985-1987 \\
\text { rel. to untreated }\end{array}$ & $\begin{array}{c}0.0772 * * * \\
(0.0186)\end{array}$ & $\begin{array}{c}0.00203 \\
(0.00154)\end{array}$ & & & $\begin{array}{c}-0.000560 * * * \\
(0.000190)\end{array}$ & $\begin{array}{l}0.000262 * * \\
(0.000118)\end{array}$ \\
\hline $\begin{array}{l}\text { Cohorts } 1982-1984 \\
\text { rel. to untreated }\end{array}$ & $\begin{array}{c}0.0100 \\
(0.0183)\end{array}$ & $\begin{array}{l}0.000503 \\
(0.00155)\end{array}$ & $\begin{array}{l}0.00138 * * * \\
(0.000292)\end{array}$ & $\begin{array}{c}0.000724 * * * \\
(0.000258)\end{array}$ & $\begin{array}{c}-0.000680 * * * \\
(0.000195)\end{array}$ & $\begin{array}{c}0.000131 \\
(0.000120)\end{array}$ \\
\hline $\begin{array}{l}\text { Cohorts } 1979-1981 \\
\text { rel. to untreated }\end{array}$ & $\begin{array}{c}0.0231 \\
(0.0195)\end{array}$ & $\begin{array}{l}-0.000367 \\
(0.00162)\end{array}$ & $\begin{array}{c}0.000183 \\
(0.000308)\end{array}$ & $\begin{array}{l}0.000621^{* *} \\
(0.000282)\end{array}$ & $\begin{array}{c}-0.000577^{* * *} \\
(0.000209)\end{array}$ & $\begin{array}{l}0.000252 * \\
(0.000129)\end{array}$ \\
\hline $\begin{array}{l}\text { Cohorts } 1977-1978 \\
\text { rel. to untreated }\end{array}$ & $\begin{array}{l}-0.0139 \\
(0.0227)\end{array}$ & $\begin{array}{c}0.00267 \\
(0.00213)\end{array}$ & $\begin{array}{l}-0.000581 \\
(0.000395)\end{array}$ & $\begin{array}{c}0.000012 \\
(0.000328)\end{array}$ & $\begin{array}{l}-0.000022 \\
(0.000278)\end{array}$ & $\begin{array}{c}0.000201 \\
(0.000165)\end{array}$ \\
\hline $\begin{array}{l}\text { Untreated Cohorts } \\
(1972-1976)\end{array}$ & $\begin{array}{l}-0.0334 * \\
(0.0173)\end{array}$ & $\begin{array}{l}0.000143 \\
(0.00155)\end{array}$ & $\begin{array}{l}-0.000191 \\
(0.000290)\end{array}$ & $\begin{array}{c}-0.00121 * * * \\
(0.000265)\end{array}$ & $\begin{array}{c}0.000744 * * * \\
(0.000195)\end{array}$ & $\begin{array}{c}-0.000333^{* * *} \\
(0.000117)\end{array}$ \\
\hline Placebo test: & Pass & Pass & Fail & Fail & Pass & Pass \\
\hline Specification & $\begin{array}{l}\text { Treatment } \\
\text { Windows }\end{array}$ & $\begin{array}{l}\text { Treatment } \\
\text { Windows }\end{array}$ & $\begin{array}{l}\text { Treatment } \\
\text { Windows }\end{array}$ & $\begin{array}{l}\text { Treatment } \\
\text { Windows }\end{array}$ & $\begin{array}{l}\text { Treatment } \\
\text { Windows }\end{array}$ & $\begin{array}{l}\text { Treatment } \\
\text { Windows }\end{array}$ \\
\hline Observations & $1,715,421$ & 610,182 & $1,120,459$ & $1,120,845$ & $1,409,092$ & $1,402,829$ \\
\hline R-squared ${ }^{\ddagger}$ & 0.186 & 0.146 & 0.126 & 0.0300 & 0.0382 & 0.0290 \\
\hline
\end{tabular}

Notes: Robust standard errors in parentheses. Statistical significance at 1, 5 and $10 \%$ level is denoted by ***, **, *. For a complete list of included covariates see Table 3. The definition of the placebo tests is explained in Section 5 . The mean of the cognitive score is 5 , the standard deviation 1.9.

† For the outcome university degree at age 25, we had to leave out household income and its squared term to achieve convergence. The results are qualitatively the same when leaving the variables in and stopping the estimation after 25 iterations, and when comparing OLS results including the variables to those that do not.

$\ddagger$ Pseudo R-squared for binary outcomes.

The point estimates for the effect of having more choice among schools on the cognitive score are very small for all cohorts and none of them is significantly different from zero. However, it shall be noted that this sample differs from the other outcomes in two aspects: First the vast majority of the draftees (more than 99 percent in our sample) are males. Second, as previously mentioned, although the draft is still mandatory, in practise it has over time become more voluntary, and among the younger cohorts, there is an increasing share who did not take the test, which raises issues of selection problems for this variable. Section 0 in the Appendix shows that the selection into taking the test is slightly related to our choice measure, but the correlation is very small. However, the fact that the draftees are predominantly males could still give rise to 
different estimates, and in order to get an idea of whether this is the case, we re-estimate the baseline specification for the outcome marks in grade 9, separately for females, males and also for the sample that is used in the draft-regression. The results, which are shown in Table 23 in the Appendix, suggest that the effect of the choice reform is a bit larger for girls than for boys. This, together with the fact that information on the draftees is lacking for the youngest cohorts, who are according to our estimates most affected by the reform, suggests that the non-significant estimates for the draft-scores could be specific to the sample of draftees.

Column three in Table 4 shows marginal effects at the mean for the probability of having a university degree at age 25. For the youngest cohorts, which is the only one for which we find a marginal effect that is significantly different from zero, we estimate an increase of 0.14 percentage points in the probability of having a university degree for each extra school within the commuting distance. This is again a very small effect. However, it shall be noted that the placebo-test for this outcome fails: students born in years 1975-1976 had a disadvantage, compared to those born between 1972-1974, from having more schools nearby ${ }^{37}$. This cannot be attributed to the reform, as the reform had not been enacted yet while cohorts 1975-1976 where in compulsory education. Since this violates our identifying assumption, the marginal effects for this outcome cannot easily be interpreted, even though the negative placebo-effect suggests that the found effect may be a lower bound. Also for the outcome "being employed at age 25", the estimates indicate a placebo-effect, although again very small. With a marginal effect of 0.12 , it is positive and in the range of the marginal effects we find for the youngest cohorts; that is an increase in the probability of being employed by 0.07 percentage points. Even though the placebo-test fails, we see that both estimates are very small, which indicates that there is no notable effect on employment at age 25.

We find nearly zero effects for the probability of ever having been convicted for a criminal offense (largest estimate is -0.07 percentage points per extra school, see column five) or having serious health problems at age 22 (only significant above the 95

\footnotetext{
37 The estimated marginal effect for cohorts $1975-1976$ is -0.12 percentage points for each additional school, so again, a very small effect.
} 
percent level for the youngest cohort, with a marginal effect of 0.026 percentage points per extra school, see column six).

Summing up, our main results, using the number of schools within the median commuting distance of the home municipality in 1991, show that more choice leads to marginally higher grades at the end of $9^{\text {th }}$ grade but does not seem to have affected our long-term outcomes in an economically significant way (keeping in mind the identification problems for some of the long-term outcomes). Although we cannot exclude possible grade inflation, additional empirical analysis suggests that it cannot be the main explanation. ${ }^{38}$ Hence, choice seems to have (very) small effects on grades, but these fade out as the children grow older.

\subsection{Sensitivity Analysis}

The results of the main analysis in the former section indicated small positive, or nonexistent, effects of choice opportunities on student short-term and long-term outcomes. This section presents a number of additional specifications that test the robustness of the main analysis.

\subsubsection{Alternative measure of choice opportunities}

First, we use another distance as cut-off value for the construction of the choice measure. Instead of defining the choice options as the number of schools available within the median commuting distance within the municipality, we use a fixed radius of $2 \mathrm{~km}$ for all municipalities. This alternative measure has the advantage of being easier to relate to and always within close reach of students' home, but has the disadvantage of not being related to the local geography. For many children who live in rather rural areas it does not even comprise the nearest school and may therefore give a too crude picture of the degree of choice in these areas, ${ }^{39}$ but it may still be too large to distinguish between choice and no-choice areas in larger cities.

\footnotetext{
${ }^{38}$ Available data on $9^{\text {th }}$ grade standardized test scores in English, Swedish and math, taken in years 2005-2008, have enabled us to partially test for different degrees of grade inflation between high and low choice areas. The results reported in Section 0 in the Appendix suggest that there is some grade inflation related to having more schools to choose from, but that its effect on our estimates is probably small.

${ }^{39}$ In terms of the exogenous pre-reform measures, $68 \%$ of the individuals in the sample have no or only one school offering grades 7-9 within 2 kilometres around their home. This share reduces to $45 \%$ when using the median commuting distance of the municipality instead.
} 
Table 5 shows the results of repeating the main estimations but using the choice measure based on the $2 \mathrm{~km}$ radius. The choice effect of having one additional school within $2 \mathrm{~km}$ on the percentile rank in $9^{\text {th }}$ grade GPA is now negative but insignificant, or marginally insignificant, for all cohorts that were already in compulsory school when the reform was enacted. For the youngest cohorts, i.e. those born between 1988 and 1990, having one more school within a $2 \mathrm{~km}$ radius of their place of residence in 1991 significantly increases the percentile rank by 0.298 . This effect is larger than the increase caused by an additional school in the median commuting distance. However, taking the observed variation into account, an increase in this choice measure by one standard deviation, that is 1.69 schools, amounts to a 0.5 percentile rank improvement in the GPA, i.e. rather close to what we find using the median commuting distance as radius.

Turning to the effect on cognitive skills as measured by the military draft test score, we can see that one more school within $2 \mathrm{~km}$ distance raises the cognitive score by about 0.01 to 0.02 points for the younger cohorts. With a standard deviation in the outcome of 1.9 , this amounts to a very small effect of $0.5-1 \%$ of a standard deviation. So again, even though we now find a significant effect, the effect is economically small. The pattern is similar for the other outcomes: the point estimates are larger when using this measure, but economically, they are still small.

As in we find again that for the outcome "employed at 25" the placebo tests fail, ${ }^{40}$ such that the result for this variable shall be interpreted with caution. Nevertheless, the estimated marginal effect is below 0.3 percentage points for each additional school within $2 \mathrm{~km}$, and thus, again, economically small. We do not find any significant effects on the probability of having been convicted for a criminal offence until age 22 or having health problems at that age.

\footnotetext{
${ }^{40}$ When estimating the probability of having received a university degree until the age of 25 , we left out household income and its squared term to achieve convergence. The results are qualitatively the same when leaving the variables in and stopping the estimation after 25 iterations, and when comparing OLS results including the variables to those that do not. The only difference is that the placebo test for the outcome "university degree at age 25 " is not significant when excluding household income and its squared term. We are therefore careful in our interpretation of these results.
} 
Summing up, we find that, qualitatively, the results are robust to using a different radius to approximate the area in which parents may consider choosing schools. ${ }^{41}$

Table 5: Estimation results using number of schools within $2 \mathrm{~km}$ as distance measure

\begin{tabular}{|c|c|c|c|c|c|c|}
\hline \multicolumn{7}{|c|}{$\begin{array}{l}\text { Choice Measure: Number of schools within } 2 \mathrm{~km} \\
\text { Grade Level: } 7-9\end{array}$} \\
\hline & $\begin{array}{l}\text { Percentile } \\
\text { Rank } \\
\text { Grade } 9\end{array}$ & $\begin{array}{l}\text { Cognitive } \\
\text { Score } \\
\text { (Men Only) }\end{array}$ & $\begin{array}{l}\text { University } \\
\text { Degree } \\
\text { at Age } 25^{\dagger}\end{array}$ & $\begin{array}{l}\text { Employed } \\
\text { Age } 25\end{array}$ & $\begin{array}{l}\text { Any Crime } \\
\text { until Age } 22\end{array}$ & $\begin{array}{l}\text { Health } \\
\text { Age } 22\end{array}$ \\
\hline $\begin{array}{l}\text { Cohorts 1988-1990 rel. to } \\
\text { untreated }\end{array}$ & $\begin{array}{l}0.298 * * * \\
(0.0570)\end{array}$ & & & & & \\
\hline $\begin{array}{l}\text { Cohorts 1985-1987 rel. to } \\
\text { untreated }\end{array}$ & $\begin{array}{c}0.0722 \\
(0.0614)\end{array}$ & $\begin{array}{l}0.0193 * * * \\
(0.00507)\end{array}$ & & & $\begin{array}{c}0.000351 \\
(0.000592)\end{array}$ & $\begin{array}{l}0.000690 * \\
(0.000413)\end{array}$ \\
\hline $\begin{array}{l}\text { Cohorts 1982-1984 rel. to } \\
\text { untreated }\end{array}$ & $\begin{array}{l}-0.115^{*} \\
(0.0602)\end{array}$ & $\begin{array}{l}0.0103 * * \\
(0.00519)\end{array}$ & $\begin{array}{c}0.00565^{* * *} \\
(0.00103)\end{array}$ & $\begin{array}{l}0.00229 * * * \\
(0.000827)\end{array}$ & $\begin{array}{c}9.73 \mathrm{e}-05 \\
(0.000628)\end{array}$ & $\begin{array}{l}-3.35 \mathrm{e}-05 \\
(0.000435)\end{array}$ \\
\hline $\begin{array}{l}\text { Cohorts 1979-1981 rel. to } \\
\text { untreated }\end{array}$ & $\begin{array}{l}-0.0729 \\
(0.0638)\end{array}$ & $\begin{array}{l}0.0110 * * \\
(0.00534)\end{array}$ & $\begin{array}{l}0.00257^{* *} \\
(0.00103)\end{array}$ & $\begin{array}{c}0.00129 \\
(0.000875)\end{array}$ & $\begin{array}{l}-0.000174 \\
(0.000658)\end{array}$ & $\begin{array}{c}0.000283 \\
(0.000441)\end{array}$ \\
\hline $\begin{array}{l}\text { Cohorts 1977-1978 rel. to } \\
\text { untreated }\end{array}$ & $\begin{array}{c}-0.106 \\
(0.0653)\end{array}$ & $\begin{array}{l}0.0138 * * \\
(0.00615)\end{array}$ & $\begin{array}{l}0.000383 \\
(0.00119)\end{array}$ & $\begin{array}{c}0.00141 \\
(0.00101)\end{array}$ & $\begin{array}{c}0.00117 \\
(0.000784)\end{array}$ & $\begin{array}{c}0.000456 \\
(0.000475)\end{array}$ \\
\hline $\begin{array}{l}\text { Untreated Cohorts } \\
(1972-1976)\end{array}$ & $\begin{array}{l}0.138 * * * \\
(0.0411)\end{array}$ & $\begin{array}{l}-0.0122^{* * *} \\
(0.00371)\end{array}$ & $\begin{array}{c}0.000259 \\
(0.000721)\end{array}$ & $\begin{array}{c}-0.00549 * * * \\
(0.000656)\end{array}$ & $\begin{array}{c}0.000524 \\
(0.000464)\end{array}$ & $\begin{array}{l}-0.000465^{*} \\
(0.000282)\end{array}$ \\
\hline Placebo test & Pass & Pass & Pass $^{\dagger}$ & Fail & Pass & Pass \\
\hline Specification & $\begin{array}{l}\text { Treatment } \\
\text { Windows }\end{array}$ & $\begin{array}{l}\text { Treatment } \\
\text { Windows }\end{array}$ & $\begin{array}{l}\text { Treatment } \\
\text { Windows }\end{array}$ & $\begin{array}{l}\text { Treatment } \\
\text { Windows }\end{array}$ & $\begin{array}{l}\text { Treatment } \\
\text { Windows }\end{array}$ & $\begin{array}{l}\text { Treatment } \\
\text { Windows }\end{array}$ \\
\hline Observations & $1,715,421$ & 610,182 & $1,120,459$ & $1,120,845$ & $1,409,092$ & $1,402,829$ \\
\hline R-squared ${ }^{\ddagger}$ & 0.186 & 0.146 & 0.126 & 0.0301 & 0.0382 & 0.0290 \\
\hline
\end{tabular}

Notes: Robust standard errors in parentheses. Statistical significance at 1,5 and $10 \%$ level is denoted by ***, **, *. For a complete list of included covariates see Table 3. The definition of the placebo tests is explained in Section 5 . The mean of the cognitive score is 5 , the standard deviation 1.9.

† For the outcome university degree at age 25, we had to leave out household income and its squared term to achieve convergence. The results are qualitatively almost the same when leaving the variables in and stopping the estimation after 25 iterations, and when comparing OLS results including the variables to those that do not. The only difference is that the Placebo test does not pass in these cases.

$\ddagger$ Pseudo R-squared for binary outcomes.

\subsubsection{Allowing the covariate coefficients to vary over time}

Second, we acknowledge that the correlation between the included covariates and students' outcomes may not be stable over time, and we allow the estimated coefficients for all municipality-level, parish-level and individual-level covariates to differ between the treatment windows. ${ }^{42}$ The results from running such estimations for all outcomes,

\footnotetext{
${ }^{41}$ Results using a radius of $3 \mathrm{~km}, 4 \mathrm{~km}$ or $5 \mathrm{~km}$ lie within the region spanned by results using 2 kilometres and the commuting distance (which is about $5 \mathrm{~km}$ on average).

${ }^{42}$ This is done by adding interactions between the treatment windows and the covariates to the regression.
} 
for the choice measures based on commuting distance and the 2 km-radius, respectively, are shown in Table 6 and Table 7. We see that altering the specification in this manner reduces the effect of choice on the percentile rank in $9^{\text {th }}$ grade GPA by half in the specification using commuting-distance for the choice measure, and even turns negative and insignificant for some cohorts when the $2 \mathrm{~km}$-choice measure is used. For the other outcomes, the effects are mostly smaller but approximately the same as for the baseline case. Qualitatively, our finding that the intention-to-treat effect of the reform is small or non-existent is thus not substantially altered. The exercise rather leads us to interpret the results on the short-term outcome "marks at the end of ninth grade" more cautiously.

Table 6: Results when allowing the coefficients for the covariates to vary between treatment windows

Choice Measure: Number of schools in median commuting distance

Grade Level: 7-9

\begin{tabular}{lcccccc}
\hline & $\begin{array}{c}\text { Percentile } \\
\text { Rank Grade } \\
9\end{array}$ & $\begin{array}{c}\text { Cognitive } \\
\text { Draft Score } \\
\text { (Men only) }\end{array}$ & $\begin{array}{c}\text { University } \\
\text { Degree } \\
\text { at Age 25 }\end{array}$ & $\begin{array}{c}\text { Employed } \\
\text { Age 25 }\end{array}$ & $\begin{array}{c}\text { Any Crime } \\
\text { until Age 22 }\end{array}$ & $\begin{array}{c}\text { Health } \\
\text { Age 22 }\end{array}$ \\
\hline $\begin{array}{l}\text { Cohorts 1988-1990 rel. } \\
\text { to untreated }\end{array}$ & $\begin{array}{c}0.0734^{* * *} \\
(0.0233)\end{array}$ & & & & & \\
Cohorts 1985-1987 rel. & 0.0326 & 0.0030 & & & $-0.0007^{* * *}$ & -0.0001 \\
to untreated & $(0.0241)$ & $(0.0020)$ & & & $(0.0003)$ & $(0.0002)$ \\
Cohorts 1982-1984 rel. & -0.0057 & 0.0015 & $0.0011^{* * *}$ & 0.0004 & $-0.0008^{* * *}$ & -0.0000 \\
to untreated & $(0.0239)$ & $(0.0020)$ & $(0.0004)$ & $(0.0003)$ & $(0.0003)$ & $(0.0002)$ \\
Cohorts 1979-1981 rel. & 0.0263 & -0.0001 & 0.0003 & $0.0008^{* *}$ & $-0.0007^{* *}$ & -0.0001 \\
to untreated & $(0.0245)$ & $(0.0021)$ & $(0.0004)$ & $(0.0004)$ & $(0.0003)$ & $(0.0002)$ \\
Cohorts 1977-1978 rel. & -0.0030 & -0.0007 & -0.0007 & 0.0004 & 0.0004 & 0.0000 \\
to untreated & $(0.0331)$ & $(0.0030)$ & $(0.0006)$ & $(0.0005)$ & $(0.0004)$ & $(0.0003)$ \\
\hline Untreated Cohorts & 0.0000 & -0.0000 & -0.0001 & $-0.0012^{* * *}$ & $0.0008^{* * *}$ & -0.0001 \\
(1972-1976) & $(0.0217)$ & $(0.0019)$ & $(0.0004)$ & $(0.0003)$ & $(0.0002)$ & $(0.0001)$ \\
& & & & & Fail \\
Placebo test: & Pass & Pass & Fail & & Pass & Pass \\
Observations & $1,715,421$ & 610,182 & $1,120,459$ & $1,120,845$ & $1,409,092$ & $1,402,829$ \\
R-squared ${ }^{\ddagger}$ & 0.187 & 0.148 & 0.127 & 0.0306 & 0.0385 & 0.0295 \\
\hline
\end{tabular}

Notes: Robust standard errors in parentheses. Statistical significance at 1, 5 and $10 \%$ level is denoted by ***, **, *. For a complete list of included covariates see Table 3.

The definition of the placebo tests is explained in Section 5. The mean of the cognitive score is 5, the standard deviation 1.9. $\ddagger$ Pseudo R-squared for binary outcomes. 
Table 7: Results using number of schools within $2 \mathrm{~km}$ as distance measure, when allowing the coefficients for the covariates to vary between treatment windows

Choice Measure: Number of schools within $2 \mathrm{~km}$ Grade Level: 7-9

\begin{tabular}{|c|c|c|c|c|c|c|}
\hline & $\begin{array}{c}\text { Percentile } \\
\text { Rank } \\
\text { Grade } 9\end{array}$ & $\begin{array}{l}\text { Cognitive } \\
\text { Score } \\
\text { (Men Only }\end{array}$ & $\begin{array}{l}\text { University } \\
\text { Degree } \\
\text { at Age } 25\end{array}$ & $\begin{array}{l}\text { Employed } \\
\text { Age } 25\end{array}$ & $\begin{array}{l}\text { Any Crime } \\
\text { until Age } 22\end{array}$ & $\begin{array}{l}\text { Health } \\
\text { Age } 22\end{array}$ \\
\hline $\begin{array}{l}\text { Cohorts } 1988-1990 \text { rel. to } \\
\text { untreated }\end{array}$ & $\begin{array}{l}-0.0613 \\
(0.0650)\end{array}$ & & & & & \\
\hline $\begin{array}{l}\text { Cohorts } 1985-1987 \text { rel. to } \\
\text { untreated }\end{array}$ & $\begin{array}{c}-0.1490 * * \\
(0.0709)\end{array}$ & $\begin{array}{c}0.0158 * * \\
(0.0065)\end{array}$ & & & $\begin{array}{c}0.0012 \\
(0.0008)\end{array}$ & $\begin{array}{l}-0.0001 \\
(0.0005)\end{array}$ \\
\hline $\begin{array}{l}\text { Cohorts 1982-1984 rel. to } \\
\text { untreated }\end{array}$ & $\begin{array}{l}-0.1420 * \\
(0.0769)\end{array}$ & $\begin{array}{l}0.0153 * * \\
(0.0066)\end{array}$ & $\begin{array}{c}0.0026 * * \\
(0.0013)\end{array}$ & $\begin{array}{c}0.0004 \\
(0.0011)\end{array}$ & $\begin{array}{l}0.0020^{* *} \\
(0.0008)\end{array}$ & $\begin{array}{l}-0.0005 \\
(0.0006)\end{array}$ \\
\hline $\begin{array}{l}\text { Cohorts 1979-1981 rel. to } \\
\text { untreated }\end{array}$ & $\begin{array}{l}-0.0043 \\
(0.0744)\end{array}$ & $\begin{array}{l}0.0168 * * \\
(0.0069)\end{array}$ & $\begin{array}{l}0.0030 * * \\
(0.0013)\end{array}$ & $\begin{array}{l}-0.0005 \\
(0.0011)\end{array}$ & $0.0016^{* *}$ & -0.0007 \\
\hline $\begin{array}{l}\text { Cohorts 1977-1978 rel. to } \\
\text { untreated }\end{array}$ & $\begin{array}{l}(0.0 / 44) \\
-0.0700 \\
(0.0793)\end{array}$ & $\begin{array}{c}(0.0069) \\
0.0075 \\
(0.0073)\end{array}$ & $\begin{array}{c}(0.0013) \\
0.0015 \\
(0.0015)\end{array}$ & $\begin{array}{c}(0.0011) \\
0.0016 \\
(0.0013)\end{array}$ & $\begin{array}{l}(0.0008) \\
0.0024^{* *} \\
(0.00105)\end{array}$ & $\begin{array}{c}(0.0006) \\
0.0005 \\
(0.0006)\end{array}$ \\
\hline $\begin{array}{l}\text { Untreated Cohorts } \\
(1972-1976)\end{array}$ & $\begin{array}{c}0.2160^{* * *} \\
(0.0450)\end{array}$ & $\begin{array}{c}-0.0112^{* * *} \\
(0.0041)\end{array}$ & $\begin{array}{c}0.0010 \\
(0.0008)\end{array}$ & $\begin{array}{c}-0.0045^{* * *} \\
(0.0007)\end{array}$ & $\begin{array}{l}-0.0005 \\
(0.0005)\end{array}$ & $\begin{array}{l}-0.0001 \\
(0.0003)\end{array}$ \\
\hline Placebo test & Pass & Pass & Pass & Fail & Pass & Pass \\
\hline Observations & $1,715,421$ & 610,182 & $1,120,459$ & $1,120,845$ & $1,409,092$ & $1,402,829$ \\
\hline R-squared ${ }^{\ddagger}$ & 0.187 & 0.148 & 0.161 & 0.038 & 0.034 & 0.014 \\
\hline
\end{tabular}

Notes: Robust standard errors in parentheses. Statistical significance at 1, 5 and $10 \%$ level is denoted by ***, **, *. For a complete list of included covariates see Table 3.

The definition of the placebo tests is explained in Section 5 . The mean of the cognitive score is 5 , the standard deviation 1.9 .

$\ddagger$ Pseudo R-squared for binary outcomes.

\subsubsection{Estimating non-linear effects of choice opportunities}

Third, we examine whether the effects of school choice may be non-linear, in the sense that going from, say, 2 to 3 schools to choose from near their home could affect student outcomes differently than going from, say, 9 to 10 schools. In order to account for this possibility, we re-estimate the regression equation, but allow the effect of choice to differ between students in different segments of the choice-distribution. In particular, we allow for the slope of the regression line to differ between the following segments of the choice-variable: 0-4 schools, 4-8 schools, 8-12 schools, and 12 and more schools, which is implemented via spline estimation. In other words, we estimate a piecewise linear function, which allows the effect of the choice reform to differ between students with the above categories of number of schools near their home.

presents the results from this exercise, showing only the preferred specification that models the treatment effect as a piecewise constant function of cohorts. The figures for the different choice-categories display the marginal effects of an additional school nearby for students that already have different degrees of potential choice. We see that 
the point estimates are mostly smallest for those that have 0-4 schools near their home, and that the effect of an additional school is often largest for those that have between 48 schools or sometimes also more than 12 schools in the area. However, the standard errors of the marginal effects are much larger than before, rendering the estimates less robust and more imprecise. There is also no clear pattern of an increasing or decreasing effect size over all categories of choice: the point estimates in the category 8-12 schools are often smaller than those in the category 4-8 or 12+. Furthermore, the variation used to identify effects of an additional school nearby when starting from an already large number of schools comes mostly from the urban areas, for which the estimated average effects tend to be larger (see the Appendix).

To sum up, this exercise shows that the choice effect of adding an additional school seems to be larger in markets that already exhibit a certain degree of choice. 
Table 8: Results when estimating the effect of choice as a piece-wise linear function

Outcome: Percentile rank GPA Grade 9

Choice Measure: Number of schools within median commuting distance Grade Level: 7-9

\begin{tabular}{|c|c|c|c|c|c|c|c|}
\hline & $\begin{array}{l}\text { Choice- } \\
\text { interval: Nr } \\
\text { Schools }\end{array}$ & $\begin{array}{l}\text { Percentile } \\
\text { Rank Grade } \\
9\end{array}$ & $\begin{array}{l}\text { Cognitive Score } \\
\text { (Men Only) }\end{array}$ & $\begin{array}{l}\text { University } \\
\text { Degree at } \\
\text { Age } 25+\end{array}$ & $\begin{array}{l}\text { Employed } \\
\text { Age } 25\end{array}$ & $\begin{array}{l}\text { Any Crime } \\
\text { until Age } 22\end{array}$ & $\begin{array}{l}\text { Health Age } \\
22\end{array}$ \\
\hline \multirow[t]{4}{*}{$\begin{array}{l}\text { Cohorts 1988-1990 rel. to } \\
\text { untreated }\end{array}$} & $0-4$ & $\begin{array}{c}-0,096 \\
(0.0694)\end{array}$ & & & & & \\
\hline & $4-8$ & $\begin{array}{c}0.376^{* * *} \\
(0.115)\end{array}$ & & & & & \\
\hline & $8-12$ & $\begin{array}{c}0.138 \\
(0.128)\end{array}$ & & & & & \\
\hline & $12-$ & $\begin{array}{l}0.192 * * * \\
(0.0425)\end{array}$ & & & & & \\
\hline \multirow[t]{6}{*}{$\begin{array}{l}\text { Cohorts 1985-1987 rel. to } \\
\text { untreated }\end{array}$} & $0-4$ & $\begin{array}{l}-0.0734 \\
(0.0729)\end{array}$ & $\begin{array}{l}-0.0016 \\
(0.0072)\end{array}$ & & & $\begin{array}{l}-0.0013 \\
(0.0008)\end{array}$ & $\begin{array}{l}0.0011^{*} \\
(0.0006)\end{array}$ \\
\hline & $4-8$ & $0.242 * *$ & $0.0306 * * *$ & & & 0.0009 & -0.0010 \\
\hline & & $(0.123)$ & $(0.0117)$ & & & $(0.0012)$ & (0.0009) \\
\hline & $8-12$ & 0.0481 & -0.0152 & & & -0.0009 & $0.0025^{* *}$ \\
\hline & & $(0.140)$ & $(0.0134)$ & & & $(0.0017)$ & $(0.0010)$ \\
\hline & $12-$ & $\begin{array}{c}0.154 * * * \\
(0.0424)\end{array}$ & $\begin{array}{l}-0.0051 \\
(0.0038)\end{array}$ & & & $\begin{array}{l}-0.0005 \\
(0.0005)\end{array}$ & $\begin{array}{c}-0.0010^{* * * *} \\
(0.0004)\end{array}$ \\
\hline \multirow[t]{6}{*}{$\begin{array}{l}\text { Cohorts 1982-1984 rel. to } \\
\text { untreated }\end{array}$} & $0-4$ & $\begin{array}{l}-0.0716 \\
(0.0781)\end{array}$ & $\begin{array}{l}-0.0053 \\
(0.0069)\end{array}$ & $\begin{array}{c}-0.0035^{* * *} \\
(0.0013)\end{array}$ & $\begin{array}{c}0.0012 \\
(0.0011)\end{array}$ & $\begin{array}{l}-0.0011 \\
(0.0009)\end{array}$ & $\begin{array}{c}0.0003 \\
(0.0006)\end{array}$ \\
\hline & $4-8$ & $\begin{array}{l}0.0663 \\
(0.130)\end{array}$ & $\begin{array}{c}0.0175 \\
(0.0116)\end{array}$ & $\begin{array}{c}0.0113^{* * *} \\
(0.0022)\end{array}$ & $\begin{array}{l}-0.0018 \\
(0.0017)\end{array}$ & $\begin{array}{c}0.0014 \\
(0.0014)\end{array}$ & $\begin{array}{c}0.0013 \\
(0.0011)\end{array}$ \\
\hline & $8-12$ & -0.0434 & -0.0056 & -0.0013 & 0.0014 & $-0.0033^{*}$ & -0.0001 \\
\hline & & $(0.145)$ & $(0.0136)$ & $(0.0025)$ & $(0.0020)$ & $(0.0017)$ & $(0.0009)$ \\
\hline & $12-$ & $0.105^{* *}$ & -0.0062 & $0.0020 * * *$ & 0.0003 & -0.0004 & $-0.0009 * *$ \\
\hline & & $(0.0428)$ & $(0.0039)$ & $(0.0007)$ & $(0.0006)$ & $(0.0005)$ & $(0.0004)$ \\
\hline \multirow{8}{*}{$\begin{array}{l}\text { Cohorts 1979-1981 rel. to } \\
\text { untreated }\end{array}$} & $0-4$ & -0.0852 & -0.0040 & $-0.0039 * * *$ & 0.0012 & 0.0002 & 0.0009 \\
\hline & & $(0.0673)$ & $(0.0067)$ & $(0.0012)$ & $(0.0010)$ & $(0.0008)$ & $(0.0006)$ \\
\hline & $4-8$ & 0.135 & $0.0202 * *$ & $0.0075 * * *$ & $-0.0027^{*}$ & 0.0002 & -0.0010 \\
\hline & & $(0.110)$ & $(0.0100)$ & $(0.0020)$ & $(0.0015)$ & $(0.0012)$ & $(0.0009)$ \\
\hline & $8-12$ & -0.0766 & -0.0112 & -0.0023 & 0.0017 & $-0.0049 * * *$ & $0.0022 * *$ \\
\hline & & $(0.140)$ & $(0.0124)$ & $(0.0024)$ & $(0.0019)$ & $(0.0016)$ & $(0.0011)$ \\
\hline & $12-$ & $0.119^{* * *}$ & $-0.0075^{*}$ & 0.0010 & 0.0005 & 0.0003 & $-0.0009 * *$ \\
\hline & & $(0.0459)$ & $(0.0040)$ & $(0.0007)$ & $(0.0007)$ & $(0.0005)$ & $(0.0004)$ \\
\hline \multirow{8}{*}{$\begin{array}{l}\text { Cohorts 1977-1978 rel. to } \\
\text { untreated }\end{array}$} & $0-4$ & -0.0506 & $0.0149 * *$ & $-0.0035^{* *}$ & -0.0014 & 0.0009 & 0.0007 \\
\hline & & $(0.0777)$ & $(0.0072)$ & $(0.0015)$ & $(0.0012)$ & (0.0009) & $(0.0006)$ \\
\hline & $4-8$ & -0.00277 & -0.0051 & 0.0009 & 0.0011 & -0.0003 & -0.0009 \\
\hline & & $(0.121)$ & $(0.0109)$ & $(0.0021)$ & $(0.0017)$ & $(0.0013)$ & $(0.0009)$ \\
\hline & $8-12$ & -0.0418 & 0.0153 & 0.0026 & 0.0001 & -0.0001 & 0.0014 \\
\hline & & $(0.157)$ & $(0.0151)$ & $(0.0029)$ & $(0.0023)$ & $(0.0022)$ & $(0.0011)$ \\
\hline & $12-$ & 0.0538 & -0.0080 & -0.0003 & -0.0005 & -0.0002 & -0.0006 \\
\hline & & $(0.0588)$ & $(0.0063)$ & $(0.0010)$ & $(0.0009)$ & $(0.0008)$ & $(0.0005)$ \\
\hline \multirow[t]{8}{*}{ Untreated Cohorts (1972-1976) } & $0-4$ & $0.179 * * *$ & $-0.0089 *$ & $0.0086 * * *$ & $-0.0068 * * *$ & $0.0027 * * *$ & $-0.0009 * *$ \\
\hline & & $(0.0469)$ & $(0.0045)$ & $(0.0009)$ & $(0.0008)$ & $(0.0006)$ & $(0.0004)$ \\
\hline & $4-8$ & 0,0061 & 0.0008 & $-0.0052 * * *$ & 0.0007 & $-0.0022 * * *$ & 0.0005 \\
\hline & & $(0.0709)$ & $(0.0066)$ & $(0.0013)$ & $(0.0011)$ & $(0.0008)$ & $(0.0006)$ \\
\hline & $8-12$ & $-0.164^{*}$ & 0,0055 & 0.0020 & 0.0003 & $0.0040 * * *$ & $-0.0017^{* * *}$ \\
\hline & & $(0.0904)$ & $(0.0091)$ & $(0.0017)$ & $(0.0015)$ & $(0.0012)$ & $(0.0005)$ \\
\hline & $12-$ & $-0.109 * * *$ & 0,0058 & $-0.0018 * * *$ & -0.0008 & 0.0003 & $0.0008^{* *}$ \\
\hline & & $(0.0389)$ & $(0.0036)$ & $(0.0006)$ & $(0.0006)$ & $(0.0005)$ & $(0.0003)$ \\
\hline Observations & & $1,715,421$ & 610,182 & $1,120,459$ & $1,120,845$ & $1,409,092$ & $1,402,829$ \\
\hline R-squared $\ddagger$ & & 0.186 & 0.146 & 0.1258 & 0.0301 & 0.0382 & 0.0290 \\
\hline
\end{tabular}

Notes: Robust standard errors in parentheses. Statistical significance at 1,5 and $10 \%$ level is denoted by ***, **, *. For a complete list of included covariates see Table 3 .

† For the outcome university degree at age 25, we had to leave out household income and its squared term to achieve convergence. The results are qualitatively the same when leaving the variables in and stopping the estimation after 25 iterations, and when comparing OLS results including the variables to those that do not.

$\ddagger$ Pseudo R-squared for binary outcomes. 


\subsection{Heterogeneity of effects with respect to region}

The previous sections explored the average effect of choice and competition introduced by the choice reform. However, it is possible that different types of municipalities have had different policies on school choice, which means that the effects may vary across municipalities. In order to address this issue, in this section, we re-estimate our baseline specifications for $9^{\text {th }}$ grade GPA and military draft test score, when we divide municipalities along the following two dimensions.

First, we analyse the effects separately for individuals living in urban and non-urban municipalities before the reform ${ }^{43}$. The reason for this division is that school choice is likely to be more of an urban phenomenon, due to for example the higher population density and easier transportation in urban areas.

Second, even for municipalities in the more urban areas, the impact of the school choice reform is likely to differ due to differences in local policy. In order to take this into account, we focus on the municipalities in the county of Stockholm and divide them into municipalities that were early or late adopters of school choice, in terms of actively facilitating and encouraging residents to make active school choices. ${ }^{44}$ The early adopters consist of those that actively encouraged school choice in the early or mid 1990s, for example through providing information on schools and how to make a choice in practise, or by having clear student-based systems for allocating resources between schools, whereas the late adopters are those where school choice became more of an issue later on in the 2000s.

\footnotetext{
${ }^{43}$ The classification of municipalities as urban and rural follows the classification of the Swedish Association of Local Authorities, see http://www.skl.se/kommuner_och_landsting/om_kommuner/kommungruppsindelning. This divides municipalities into nine categories (Metropolitan, suburban, large cities, commuter, sparsely populated, manufacturing, and other - divided into population $>25,000,12,500-25,000$ and $<12,500$ ) on the basis of structural parameters such as population, commuting patterns and economic structure as of Jan 12005 . We classify a municipality as urban if it is thus defined as a city, suburb or "large town". This results in 68 municipalities being labeled as urban.

${ }^{44}$ In order to make this division of the sample, we contacted the municipalities in the county of Stockholm and asked them if they have a policy to actively facilitate and encourage residents to make an active school choice, and if so, when this policy was implemented. It shall be noted that, even though school choice is today a normal phenomenon in these urban municipalities, it was often not easy to find out exactly when it became common practise. The information gathered is therefore often not very detailed. In addition, we failed to receive answers from 11 out of 26 municipalities, although most of the non-respondents were the smaller municipalities in the county. The respondents were the following municipalities: Danderyd, Tyresö, Sollentuna, Haninge, Nacka, Norrtälje, Vallentuna, UpplandsBro, Stockholm, Upplands-Väsby, Huddinge, Salem, Ekerö, Botkyrka and Täby. The non-respondents were: Lidingö, Solna, Sundbyberg, Södertälje, Järfälla, Österåker, Värmdö, Nykvarn, Vaxholm, Sigtuna and Nynäshamn. The following of these were classified as being early adopters of school choice: Tyresö, Stockholm, Vallentuna, Nacka, Danderyd, Täby and Upplands-Bro.
} 
Table 9 and Table 10 present separate estimations for the two groups of urban and non-urban municipalities, and Table 11 and Table 12 show the corresponding for the two groups of early and late school choice adopters within Stockholm county.

Focusing first on the division of municipalities into urban and non-urban, the overall pattern in Table 9 and Table 10 is that school choice is related to more positive outcomes in the urban municipalities, while there is some indication of a negative relation for the non-urban municipalities. Specifically, the regressions on $9^{\text {th }}$ grade GPA (see Table 9 Columns 3 and 5) yield positive and statistically significant estimates for the treated cohorts in the urban municipalities, which are similar to the estimates from the pooled baseline specification (see first Column in Table 4). In contrast, the estimation including only non-urban municipalities yields non-significant effects when the median commuting distance is used, see Column 2, although the empirical identification is problematic for this outcome ${ }^{45}$, and negative effects when we use the choice-measure based on the 2-km radius (Table 9, Column 4). With around -0.4 to -0.5 percentile ranks per additional school, the effect is however small, especially when taking into account that the standard deviation of this choice measure in non-urban areas is only 0.85 . We conclude that the positive, albeit small, estimated effect of school choice seems to be limited to the urban municipalities, and that there is some, although weak, evidence of negative effects in the non-urban municipalities.

The estimates for the outcome cognitive skills from the military draft test scores in Table 10 show, similarly to the main estimations, little evidence of any significant effect when using the median commuting distance as radius (Columns 1-2), while the radius $2 \mathrm{~km}$ yields small positive effects of more choice in both urban and non-urban municipalities, although the estimates are almost only significant for the former.

\footnotetext{
${ }^{45}$ Note that the result in column 1 suggests statistically significant estimates for the youngest cohorts and those born between 1982 and 1984. However, we also find a significantly negative placebo effect of -0.251 percentile rank, implying that the negative effects were not necessarily caused by the reform but already there before it was enacted. When we include a pre-reform trend and interact all our treatment windows with the trend (Equation 5), this placebotest is no longer significant, though the pre-reform trend also is not. In this specification, shown in the second column, the standard errors are much larger and the point estimates are now positive and no longer significantly different from zero. However, since the pre-reform trend that is estimated on cohorts 1972-1976 is being extrapolated to form a control group as far as 14 years into the future, this specification is very sensitive to the estimated trend. Since the pre-reform trend is not even statistically significant from zero, one should be very cautious in interpreting this result.
} 
Table 9: Heterogeneity of effects with respect to urban vs. non-urban municipalities and outcome percentile rank GPA 9

Outcome: Percentile rank Grades 9

Choice Measure: Number of schools within radius...

Grade Level: $7-9$

Radius: median commuting distance

Radius: $2 \mathrm{~km}$

\begin{tabular}{|c|c|c|c|c|c|}
\hline & & \multirow[b]{2}{*}{$\begin{array}{c}\text { Non-urban } \\
\text { area }\end{array}$} & \multirow[b]{2}{*}{ Urban Area } \\
\hline & \multicolumn{2}{|c|}{ Non-urban area } & Urban area & & \\
\hline \multirow{2}{*}{$\begin{array}{l}\text { Cohorts 1988-1990 rel. to } \\
\text { untreated }\end{array}$} & $-0.235 * *$ & 0.807 & $0.147 * * *$ & $-0.494 * * *$ & $0.349 * * *$ \\
\hline & $(0.0914)$ & $(0.682)$ & $(0.0201)$ & $(0.122)$ & $(0.0646)$ \\
\hline \multirow{2}{*}{$\begin{array}{l}\text { Cohorts 1985-1987 rel. to } \\
\text { untreated }\end{array}$} & -0.0715 & 0.763 & $0.102 * * *$ & $-0.419 * * *$ & $0.165^{* *}$ \\
\hline & $(0.0942)$ & $(0.549)$ & $(0.0205)$ & $(0.131)$ & $(0.0702)$ \\
\hline \multirow{2}{*}{$\begin{array}{l}\text { Cohorts 1982-1984 rel. to } \\
\text { untreated }\end{array}$} & $-0.198 * *$ & 0.426 & $0.0409 * *$ & $-0.369 * * *$ & 0.0325 \\
\hline & $(0.0942)$ & $(0.414)$ & $(0.0200)$ & $(0.138)$ & $(0.0681)$ \\
\hline \multirow{2}{*}{$\begin{array}{l}\text { Cohorts 1979-1981 rel. to } \\
\text { untreated }\end{array}$} & -0.107 & 0.291 & $0.0497 * *$ & -0.153 & 0.0130 \\
\hline & (0.0929) & $(0.284)$ & $(0.0216)$ & $(0.126)$ & $(0.0747)$ \\
\hline \multirow{2}{*}{$\begin{array}{l}\text { Cohorts 1977-1978 rel. to } \\
\text { untreated }\end{array}$} & -0.0604 & 0.182 & 0.00708 & -0.193 & -0.0118 \\
\hline & (0.115) & (0.196) & $(0.0248)$ & $(0.144)$ & (0.0739) \\
\hline \multirow{2}{*}{$\begin{array}{l}\text { Untreated Cohorts } \\
(1972-1976)\end{array}$} & $0.250 * * *$ & & $-0.0632 * * *$ & $0.385^{* * *}$ & 0.0562 \\
\hline & $(0.0695)$ & & $(0.0189)$ & $(0.0843)$ & $(0.0470)$ \\
\hline \multicolumn{6}{|l|}{ Coefficients } \\
\hline \multirow[t]{2}{*}{ Choice } & & $0.392^{* * *}$ & & & \\
\hline & & $(0.115)$ & & & \\
\hline \multirow{2}{*}{$\begin{array}{l}\text { Trend } \times \text { Choice } \\
\text { (pre-reform trend) }\end{array}$} & & -0.0699 & & & \\
\hline & & $(0.0453)$ & & & \\
\hline \multirow[t]{2}{*}{ Constant } & $15.93 * *$ & $16.95^{* *}$ & $30.33 * * *$ & $17.31^{* *}$ & $24.40 * * *$ \\
\hline & (6.959) & (6.996) & $(6.216)$ & (6.960) & $(6.471)$ \\
\hline Placebo test & Fail & Pass & Pass & Pass & Pass \\
\hline \multirow{2}{*}{ Specification } & Treatment & Treatment & Treatment & Treatment & Treatment \\
\hline & Windows & Windows $\times$ Trend & Windows & Windows & Windows \\
\hline Observations & 784,494 & 784,494 & 930,927 & 784,494 & 930,927 \\
\hline R-squared & 0.164 & 0.164 & 0.199 & 0.164 & 0.199 \\
\hline
\end{tabular}

Notes: Robust standard errors in parentheses. Statistical significance at 1, 5 and 10\% level is denoted by ***, **, *.

For a complete list of included covariates see Table 3. The definition of the placebo tests is explained in Section 5. 
Table 10: Heterogeneity of effects with respect to urban vs. non-urban municipalities and outcome cognitive skills

Outcome: Cognitive skills

Choice Measure: Number of schools within radius...

Grade Level: 7-9

\begin{tabular}{|c|c|c|c|c|}
\hline & \multicolumn{2}{|c|}{ Radius: median commuting distance } & \multicolumn{2}{|c|}{ Radius: $2 \mathrm{~km}$} \\
\hline & Non-urban Area & Urban area & Non-urban area & Urban area \\
\hline $\begin{array}{l}\text { Cohorts 1985-1987 rel. to } \\
\text { untreated }\end{array}$ & $\begin{array}{l}0.0194 * * \\
(0.00954)\end{array}$ & $\begin{array}{c}0.00146 \\
(0.00172)\end{array}$ & $\begin{array}{c}0.0114 \\
(0.0135)\end{array}$ & $\begin{array}{l}0.0223 * * * \\
(0.00589)\end{array}$ \\
\hline $\begin{array}{l}\text { Cohorts 1982-1984 rel. to } \\
\text { untreated }\end{array}$ & $\begin{array}{c}0.0121 \\
(0.00885)\end{array}$ & $\begin{array}{l}0.000786 \\
(0.00174)\end{array}$ & $\begin{array}{l}0.0243^{*} \\
(0.0135)\end{array}$ & $\begin{array}{l}0.0145^{* *} \\
(0.00612)\end{array}$ \\
\hline $\begin{array}{l}\text { Cohorts 1979-1981 rel. to } \\
\text { untreated }\end{array}$ & $\begin{array}{c}0.00757 \\
(0.00946)\end{array}$ & $\begin{array}{l}-0.000396 \\
(0.00183)\end{array}$ & $\begin{array}{l}0.00816 \\
(0.0127)\end{array}$ & $\begin{array}{l}0.0154^{* *} \\
(0.00637)\end{array}$ \\
\hline $\begin{array}{l}\text { Cohorts 1977-1978 rel. to } \\
\text { untreated }\end{array}$ & $\begin{array}{l}0.00583 \\
(0.0115)\end{array}$ & $\begin{array}{l}0.000771 \\
(0.00239)\end{array}$ & $\begin{array}{c}0.0125 \\
(0.0146)\end{array}$ & $\begin{array}{c}0.0118 * \\
(0.00710)\end{array}$ \\
\hline $\begin{array}{l}\text { Untreated Cohorts (1972- } \\
\text { 1976) }\end{array}$ & $\begin{array}{l}-0.0146 * * \\
(0.00675)\end{array}$ & $\begin{array}{l}0.000842 \\
(0.00170)\end{array}$ & $\begin{array}{c}-0.0270^{* * *} \\
(0.00840)\end{array}$ & $\begin{array}{c}-0.0110^{* * *} \\
(0.00426)\end{array}$ \\
\hline Constant & $\begin{array}{c}0.927 \\
(0.639)\end{array}$ & $\begin{array}{c}2.566 * * * \\
(0.473)\end{array}$ & $\begin{array}{c}0.968 \\
(0.639)\end{array}$ & $\begin{array}{c}2.229 * * * \\
(0.471)\end{array}$ \\
\hline Placebo test & Pass & Pass & Pass & Pass \\
\hline Specification & $\begin{array}{l}\text { Treatment } \\
\text { Windows }\end{array}$ & $\begin{array}{l}\text { Treatment } \\
\text { Windows }\end{array}$ & $\begin{array}{l}\text { Treatment } \\
\text { Windows }\end{array}$ & $\begin{array}{l}\text { Treatment } \\
\text { Windows }\end{array}$ \\
\hline Observations & 281,734 & 328,448 & 281,734 & 328,448 \\
\hline R-squared & 0.124 & 0.161 & 0.124 & 0.161 \\
\hline
\end{tabular}

Notes: Robust standard errors in parentheses. Statistical significance at 1, 5 and $10 \%$ level is denoted by ***, **, *. For a complete list of included covariates see Table 3. The definition of the placebo tests is explained in Section 5. The mean of the cognitive score is 5 , the standard deviation 1.9.

Turning to the division between early and late adopters among the municipalities in Stockholm county ${ }^{46}$, Table 11 shows that when we use the choice-measure based on median commuting distance (Columns 1-2), students living in the early-choiceadopting municipalities seem to have benefited slightly more in terms of receiving higher grades, while students in the late choice-municipalities sometimes even have a negative effect of having more schools nearby. However, this effect disappears when looking at the measure using a $2 \mathrm{~km}$ radius: In Columns $3-4$, we see that students in both municipalities seem to have benefited from having more schools nearby, even though

\footnotetext{
${ }^{46}$ Naturally, the sample for this analysis is restricted to students living in municipalities, that provided information in our survey, in 1991 or the year they make the decision to start $7^{\text {th }}$ grade, if that was before 1991 , respectively.
} 
the standard errors are a bit larger in the smaller sample living in the "late-adopting" municipalities, thus causing the marginal effects to be less often statistically significant.

Table 12 presents results for the outcome cognitive skills. They indicate some significantly negative effects of having more schools nearby in the "late-adopting" municipalities, when we use the larger radius "commuting distance". However, the negative effects and the differences between the two groups vanish when using the $2 \mathrm{~km}$ radius for the Stockholm region.

Table 11: Heterogeneity of effects within Stockholm county and outcome percentile rank GPA 9

Outcome: Percentile rank Grades 9

Choice Measure: Number of schools within...

Sample: early vs. late adopters within Stockholm

Grade Level: 7-9

\begin{tabular}{|c|c|c|c|c|}
\hline & \multicolumn{2}{|c|}{$\begin{array}{c}\text { Radius: median } \\
\text { commuting distance }\end{array}$} & \multicolumn{2}{|c|}{ Radius: $2 \mathrm{~km}$} \\
\hline & $\begin{array}{c}\text { Late } \\
\text { Adopter }\end{array}$ & $\begin{array}{c}\text { Early } \\
\text { Adopter }\end{array}$ & $\begin{array}{c}\text { Late } \\
\text { Adopter }\end{array}$ & $\begin{array}{c}\text { Early } \\
\text { Adopter }\end{array}$ \\
\hline Cohorts 1988-1990 rel. to untreated & $\begin{array}{l}-0.130 \\
(0.0948)\end{array}$ & $\begin{array}{l}0.129 * * * \\
(0.0432)\end{array}$ & $\begin{array}{l}0.577^{*} \\
(0.316)\end{array}$ & $\begin{array}{c}0.557 * * * \\
(0.123)\end{array}$ \\
\hline Cohorts 1985-1987 rel. to untreated & $\begin{array}{l}-0.158^{*} \\
(0.0951)\end{array}$ & $\begin{array}{l}0.0866^{*} \\
(0.0457)\end{array}$ & $\begin{array}{l}0.0931 \\
(0.332)\end{array}$ & $\begin{array}{c}0.437 * * * \\
(0.142)\end{array}$ \\
\hline Cohorts 1982-1984 rel. to untreated & $\begin{array}{l}-0.194 * * \\
(0.0946)\end{array}$ & $\begin{array}{c}0.0382 \\
(0.0462)\end{array}$ & $\begin{array}{c}0.458 \\
(0.345)\end{array}$ & $\begin{array}{c}0.178 \\
(0.141)\end{array}$ \\
\hline Cohorts 1979-1981 rel. to untreated & $\begin{array}{c}-0.156 \\
(0.0952)\end{array}$ & $\begin{array}{c}0.0238 \\
(0.0463)\end{array}$ & $\begin{array}{c}1.027 * * * \\
(0.330)\end{array}$ & $\begin{array}{l}-0.0572 \\
(0.155)\end{array}$ \\
\hline Cohorts 1977-1978 rel. to untreated & $\begin{array}{l}-0.0285 \\
(0.137) \\
\end{array}$ & $\begin{array}{l}-0.00243 \\
(0.0426)\end{array}$ & $\begin{array}{c}0.663 \\
(0.411)\end{array}$ & $\begin{array}{l}0.0281 \\
(0.142)\end{array}$ \\
\hline Untreated Cohorts (1972-1976) & $\begin{array}{l}0.216^{* *} \\
(0.0979)\end{array}$ & $\begin{array}{l}-0.0823^{* *} \\
(0.0348)\end{array}$ & $\begin{array}{l}-0.242 \\
(0.243)\end{array}$ & $\begin{array}{c}-0.149 \\
(0.0944)\end{array}$ \\
\hline Constant & $\begin{array}{l}-37.56 \\
(68.16)\end{array}$ & $\begin{array}{c}29.27 * * * \\
(8.584)\end{array}$ & $\begin{array}{l}-4.459 \\
(67.65)\end{array}$ & $\begin{array}{c}27.36^{* * * *} \\
(8.379)\end{array}$ \\
\hline $\begin{array}{l}\text { Placebo test } \\
\text { Specification }\end{array}$ & \begin{tabular}{l}
\multicolumn{1}{c}{ Pass } \\
Treatment \\
Windows
\end{tabular} & \begin{tabular}{l}
\multicolumn{1}{c}{ Pass } \\
Treatment \\
Windows
\end{tabular} & \begin{tabular}{l}
\multicolumn{1}{c}{ Pass } \\
Treatment \\
Windows
\end{tabular} & $\begin{array}{c}\text { Pass } \\
\text { Treatment } \\
\text { Windows }\end{array}$ \\
\hline $\begin{array}{l}\text { Observations } \\
\text { R-squared }\end{array}$ & $\begin{array}{c}83,024 \\
0.176 \\
\end{array}$ & $\begin{array}{c}144,247 \\
0.205 \\
\end{array}$ & $\begin{array}{c}83,024 \\
0.176 \\
\end{array}$ & $\begin{array}{c}144,247 \\
0.205 \\
\end{array}$ \\
\hline
\end{tabular}

Notes: Robust standard errors in parentheses. Statistical significance at 1, 5 and $10 \%$ level is denoted by $* * *, * *, *$. For a complete list of included covariates see Table 3. The definition of the placebo tests is explained in Section 5. 
Table 12: Heterogeneity of effects within Stockholm county and outcome cognitive skills

Outcome: Cognitive skills

Choice Measure: Number of schools within radius...

Sample: early vs. late adopters in Stockholm

Grade Level: 7-9

\begin{tabular}{|c|c|c|c|c|}
\hline & \multicolumn{2}{|c|}{$\begin{array}{c}\text { RADIUS: MEDIAN } \\
\text { COMMUTING DISTANCE }\end{array}$} & \multicolumn{2}{|c|}{ RADIUS: 2KM } \\
\hline & $\begin{array}{c}\text { Late } \\
\text { Adopter }\end{array}$ & $\begin{array}{l}\text { Early } \\
\text { Adopter }\end{array}$ & $\begin{array}{c}\text { Late } \\
\text { Adopter }\end{array}$ & $\begin{array}{c}\text { Early } \\
\text { Adopter }\end{array}$ \\
\hline Cohorts 1985-1987 rel. to untreated & $\begin{array}{c}-0.0233 * * * \\
(0.00832)\end{array}$ & $\begin{array}{l}-0.00101 \\
(0.00357)\end{array}$ & $\begin{array}{l}0.0519 * \\
(0.0313)\end{array}$ & $\begin{array}{c}-0.000437 \\
(0.0116)\end{array}$ \\
\hline Cohorts 1982-1984 rel. to untreated & $\begin{array}{c}-0.0292 * * * \\
(0.00834)\end{array}$ & $\begin{array}{l}-0.000454 \\
(0.00375)\end{array}$ & $\begin{array}{c}0.0209 \\
(0.0319)\end{array}$ & $\begin{array}{l}-0.0216 * \\
(0.0120)\end{array}$ \\
\hline Cohorts 1979-1981 rel. to untreated & $\begin{array}{c}-0.0298 * * * \\
(0.00840)\end{array}$ & $\begin{array}{l}-0.000499 \\
(0.00371)\end{array}$ & $\begin{array}{c}0.0256 \\
(0.0327)\end{array}$ & $\begin{array}{l}-0.00473 \\
(0.0123)\end{array}$ \\
\hline Cohorts 1977-1978 rel. to untreated & $\begin{array}{l}-0.0178 \\
(0.0117)\end{array}$ & $\begin{array}{l}-0.00617 \\
(0.00456)\end{array}$ & $\begin{array}{l}0.00655 \\
(0.0367)\end{array}$ & $\begin{array}{c}0.000848 \\
(0.0148)\end{array}$ \\
\hline Untreated Cohorts (1972-1976) & $\begin{array}{l}0.0301 * * * \\
(0.00873)\end{array}$ & $\begin{array}{c}0.00320 \\
(0.00285)\end{array}$ & $\begin{array}{l}0.00244 \\
(0.0225)\end{array}$ & $\begin{array}{c}-0.0138 \\
(0.00878)\end{array}$ \\
\hline Constant & $\begin{array}{c}3.349 \\
(6.795)\end{array}$ & $\begin{array}{l}1.871 * * \\
(0.783)\end{array}$ & $\begin{array}{c}5.119 \\
(6.636)\end{array}$ & $\begin{array}{c}2.201^{* * *} \\
(0.792)\end{array}$ \\
\hline $\begin{array}{l}\text { Placebo test } \\
\text { Specification }\end{array}$ & \begin{tabular}{l}
\multicolumn{1}{c}{ Pass } \\
Treatment \\
Windows
\end{tabular} & \begin{tabular}{c}
\multicolumn{1}{c}{ Pass } \\
Treatment \\
Windows
\end{tabular} & \begin{tabular}{l}
\multicolumn{1}{c}{ Pass } \\
Treatment \\
Windows
\end{tabular} & \begin{tabular}{l}
\multicolumn{1}{c}{ Pass } \\
Treatment \\
Windows
\end{tabular} \\
\hline $\begin{array}{l}\text { Observations } \\
\text { R-squared }\end{array}$ & $\begin{array}{c}28,684 \\
0.167\end{array}$ & $\begin{array}{c}48,433 \\
0.166\end{array}$ & $\begin{array}{c}28,684 \\
0.166\end{array}$ & $\begin{array}{c}48,433 \\
0.167\end{array}$ \\
\hline
\end{tabular}

Summarizing, we find that having more schools nearby right after the reform seems to have had more positive effects on marks and cognitive skills of students living in urban areas at that time, even though the size of the effect is still small. Looking at Stockholm county only, differences only show up when using the radius "commuting distance” to measure choice, but mostly vanish when using the $2 \mathrm{~km}$-radius.

\subsection{Disentangling the effects of choice and competition}

As discussed in Section 3, the school choice reform might have affected student outcomes through various channels. On the one hand, students have more choice, and on the other hand schools may compete to attract students. While these concepts are related in the sense that they both stem from the school choice reform, they are distinct 
in the sense that they refer to distinct channels through which the reform could affect student outcomes. The former, choice, refers to effects that are directly related to students making school choices, such as effects through matching between student and school, or through changing peer composition. The latter, competition, instead refers to the competitive pressure that could arise as a result of school choice, and is hence a more indirect result of opening up for school choice.

In this section, we try to distinguish these two mechanisms - competition and choice - by adding a competition variable to the estimations. Since it is not obvious which is the appropriate radius for measuring choice and competition, we will present results for different definitions of choice and competition in order to gauge the sensitivity of the results. ${ }^{47}$ It serves to emphasize that even though choice and competition as conceptually different, they are of course in practise closely related: where there are large possibilities for choice, we also expect larger competition between schools. This means that separating their effects on student outcomes is bound to be cumbersome. In this section we attempt to generate a measure of competition which both meets the criterion of being relevant and that of being sufficiently different from our choice measure to avoid estimation problems due to multicollinearity.

This is done by constructing, for each school, the competitive pressure it experiences by taking into account the number of nearby schools as well as the size of their student bodies. The exact formula for the competition measure comp of school $j$ is:

$$
\operatorname{comp}_{j}=\sum_{k=1}^{K} \frac{1}{\operatorname{dist}_{k, j}} \cdot \text { size }_{k},
$$

where $k=1, \ldots, K$ indexes potential competitors within a radius of $100 \mathrm{~km}$, dist ${ }_{k, j}$ is the distance between school $\mathrm{j}$ and school $\mathrm{k}$ and size $_{\mathrm{k}}$ is the number of students visiting school $k .{ }^{48}$ We assign each student the competition measure of the school she attends in

\footnotetext{
${ }^{47}$ It should also be kept in mind that assigning a competition measure to a student is less accurate than assigning a choice measure, as we cannot use the actual school the student went to for affected cohorts.

${ }^{48}$ We will also use alternative measures of competition where we simply count the number of schools within a certain distance of the school. We note that the appropriate geographical range for the definition of competition is clearly ambiguous since competitive pressure might be felt at different levels. At first sight it appears that the school director should mostly be concerned about being compared to its immediate neighbours. In addition, though, there is a competition for good teachers, particularly when larger numbers of new private schools opened up who need to hire
} 
$9^{\text {th }}$ grade, or, for post-reform cohorts, of the closest school offering grades 7-9 measured in year 1991. ${ }^{49}$

The resulting measure of competition is related to the measure of school choice but still has a number of distinct features. First, while a student's choice options are not directly influenced by the relative size of the schools she might attend, the competitive pressure a school (director) faces from a neighbouring school is strongly influenced by the capacity of the competing school to take up a significant share of its own students. Second, while only schools that offer the grade level a student plans to attend in the following school year are relevant for her choice, schools will also feel competitive pressure from schools that offer other common grade levels.

Nevertheless, as discussed above, the measures for school competition and school choice capture similar phenomena and are therefore highly correlated, and the results shall therefore be interpreted with caution. Table 13 shows descriptive statistics for our competition measure separately for affected and non-affected cohorts. ${ }^{50}$ The large difference in the average competition measure for the two cohort groups, i.e. 7.13 compared to 14.6, is due to the fact that starting from 1994, we include schools also in other municipalities as competitors, since a law change from this year at least in theory opened up for choosing a school - public or private - in another municipality, something which was for public school in general only possible under certain circumstances.

teachers. Yet teacher labour markets certainly pass beyond the immediate vicinity. We therefore also examined various other definitions of competition in our robustness analyses.

${ }^{49}$ Competition will more likely have an effect in all classes 7-9. However, in order to make it more comparable to the choice measure, we count the number of schools again at the point in time when the decision for a school is made. Since school codes cannot be linked over time in our dataset, when assigning the actual school the child went to, which we only know in grade 9, we measure competition around the child's school in grade 9. For students born in the year 1977 and 1978, who attended $9^{\text {th }}$ grade after the reform, we will assign the competition measure of the closest school when they started grade 7 .

${ }^{50}$ Non-affected cohorts are those that have left $9^{\text {th }}$ grade before autumn 1992, i.e. before the reform. These are all students born in the years 1972 to 1976. Note that this way of assigning the competition measure requires more information than the assignment of choice measures. In particular, in order to assign the competition measure for nonaffected cohorts, we need to know the school-code that the individual went to. Since this is sometimes missing or a school might be missing in the data, we have fewer observations for the competition measure. 
Table 13: Descriptive statistics for the competition measure

\begin{tabular}{|c|c|c|c|c|c|c|c|c|}
\hline & \multicolumn{4}{|c|}{$\begin{array}{l}\text { PRE-REFORM COHORTS } \\
\text { (cohorts 1972-1976 are not affected) }\end{array}$} & \multicolumn{4}{|c|}{$\begin{array}{l}\text { POST-REFORM COHORTS } \\
\text { (cohorts 1977-1990 are affected) }\end{array}$} \\
\hline & Mean & Std. Dev. & Median & Obs. & Mean & Std. Dev. & Median & Obs. \\
\hline \multicolumn{9}{|l|}{ School competition } \\
\hline $\begin{array}{l}\text { No. of schools within } \\
100 \mathrm{~km} \text {, weighted by } \\
\text { distance and size of } \\
\text { student body }\end{array}$ & 7.13 & 11.24 & 3.70 & 412203 & 14.60 & 17.44 & 8.61 & 1306494 \\
\hline
\end{tabular}

Table 14 shows the effect of choice and competition at grade level 7-9 on the percentile rank in GPA in grade 9 for different combinations of our choice and competition measures, when including both measures in the regression. The first two rows of the table display which measure was used for choice and which one for competition. In column one, choice is defined as the number of schools within the median commuting distance and competition as the number of schools within a $100 \mathrm{~km}$ radius, weighted by their distance and student body size (see Equation 6) for the mathematical formula). Columns two to five show the results for all combinations of choice and competition measures that count the number of schools within a $2 \mathrm{~km}$ and the median commuting distance radius ${ }^{51}$.

The overall pattern that emerges from this exercise is that the positive but small effect of choice that was found in the baseline analysis is in most specifications robust to adding our measures of competition. The size of the choice effects is fairly similar to the baseline result: whereas they vary between the specifications in the table, they are always small, and are often positive and statistically significant.

\footnotetext{
${ }^{51}$ We do not show the combination: choice $2 \mathrm{~km}$ with competition $100 \mathrm{~km}$, since the geographical reach of these measures is too different.
} 
Table 14: Results disentangling effects of choice and competition

Outcome: Percentile rank GPA in Grade 9

Choice Measure: Number of schools within certain radius around students' home

Competition Measure: Number of other schools within certain radius around school

Grade Level: 7-9

\begin{tabular}{|c|c|c|c|c|c|}
\hline & \multicolumn{3}{|c|}{ Radius: median commuting distance } & \multicolumn{2}{|c|}{ Radius: $2 \mathrm{~km}$} \\
\hline & $\begin{array}{l}\text { Weighted by } \\
\text { distance and } \\
\text { student body } \\
\text { size }\end{array}$ & $\begin{array}{l}\text { Radius: } \\
\text { median } \\
\text { commuting } \\
\text { distance }\end{array}$ & $\begin{array}{l}\text { Radius: } \\
2 \mathrm{~km}\end{array}$ & $\begin{array}{l}\text { Radius: } \\
\text { median } \\
\text { commuting } \\
\text { distance }\end{array}$ & $\begin{array}{l}\text { Radius: } \\
2 \mathrm{~km}\end{array}$ \\
\hline \multicolumn{6}{|l|}{ Choice } \\
\hline $\begin{array}{l}\text { Cohorts 1988-1990 rel. to } \\
\text { untreated }\end{array}$ & $\begin{array}{l}0.116^{* * *} \\
(0.0200)\end{array}$ & $\begin{array}{l}0.237 * * * \\
(0.0330)\end{array}$ & $\begin{array}{l}0.157 * * * \\
(0.0204)\end{array}$ & $\begin{array}{c}0.114^{*} \\
(0.0631)\end{array}$ & $\begin{array}{l}0.236 * * * \\
(0.0751)\end{array}$ \\
\hline $\begin{array}{l}\text { Cohorts } 1985-1987 \text { rel. to } \\
\text { untreated }\end{array}$ & $\begin{array}{c}0.0865^{* * * *} \\
(0.0204)\end{array}$ & $\begin{array}{l}0.212 * * * \\
(0.0325)\end{array}$ & $\begin{array}{l}0.112 * * * \\
(0.0208)\end{array}$ & $\begin{array}{c}0.0159 \\
(0.0665)\end{array}$ & $\begin{array}{c}0.106 \\
(0.0749)\end{array}$ \\
\hline $\begin{array}{l}\text { Cohorts 1982-1984 rel. to } \\
\text { untreated }\end{array}$ & $\begin{array}{c}0.0315 \\
(0.0200)\end{array}$ & $\begin{array}{c}0.167 * * * \\
(0.0328)\end{array}$ & $\begin{array}{l}0.0459 * * \\
(0.0205)\end{array}$ & $\begin{array}{l}-0.0514 \\
(0.0667)\end{array}$ & $\begin{array}{l}-0.0265 \\
(0.0762)\end{array}$ \\
\hline $\begin{array}{l}\text { Cohorts 1979-1981 rel. to } \\
\text { untreated }\end{array}$ & $\begin{array}{c}0.0611^{* * *} \\
(0.0208)\end{array}$ & $\begin{array}{l}0.216^{* * *} \\
(0.0353)\end{array}$ & $\begin{array}{c}0.0695 * * * \\
(0.0212)\end{array}$ & $\begin{array}{c}0.0817 \\
(0.0697)\end{array}$ & $\begin{array}{c}0.133^{*} \\
(0.0754)\end{array}$ \\
\hline $\begin{array}{l}\text { Cohorts 1977-1978 rel. to } \\
\text { untreated }\end{array}$ & $\begin{array}{c}0.0343 \\
(0.0249)\end{array}$ & $\begin{array}{l}0.236 * * * \\
(0.0416)\end{array}$ & $\begin{array}{c}0.0377 \\
(0.0264)\end{array}$ & $\begin{array}{c}0.130^{*} \\
(0.0767)\end{array}$ & $\begin{array}{c}0.116 \\
(0.0819)\end{array}$ \\
\hline $\begin{array}{l}\text { Untreated Cohorts (1972- } \\
\text { 1976) }\end{array}$ & $\begin{array}{c}-0.0492 * * * \\
(0.0182)\end{array}$ & $\begin{array}{c}-0.179 * * * \\
(0.0299)\end{array}$ & $\begin{array}{c}-0.0742 * * * \\
(0.0196)\end{array}$ & $\begin{array}{l}0.112^{* *} \\
(0.0461)\end{array}$ & $\begin{array}{c}0.0342 \\
(0.0523)\end{array}$ \\
\hline \multicolumn{6}{|l|}{ Competition } \\
\hline $\begin{array}{l}\text { Cohorts 1989-1990 rel. to } \\
\text { untreated }\end{array}$ & $\begin{array}{c}0.00928 \\
(0.00966)\end{array}$ & $\begin{array}{c}-0.126 * * * \\
(0.0388)\end{array}$ & $\begin{array}{l}-0.0486 \\
(0.0883)\end{array}$ & $\begin{array}{l}0.0584^{* *} \\
(0.0268)\end{array}$ & $\begin{array}{l}0.0531 \\
(0.104)\end{array}$ \\
\hline $\begin{array}{l}\text { Cohorts 1986-1988 rel. to } \\
\text { untreated }\end{array}$ & $\begin{array}{l}-0.0152 * \\
(0.00892)\end{array}$ & $\begin{array}{l}-0.162 * * * \\
(0.0372)\end{array}$ & $\begin{array}{c}-0.233^{* * *} \\
(0.0876)\end{array}$ & $\begin{array}{c}0.0121 \\
(0.0259)\end{array}$ & $\begin{array}{c}-0.135 \\
(0.0985)\end{array}$ \\
\hline $\begin{array}{l}\text { Cohorts 1983-1985 rel. to } \\
\text { untreated }\end{array}$ & $\begin{array}{l}-0.0221 * * \\
(0.00922)\end{array}$ & $\begin{array}{c}-0.178 * * * \\
(0.0375)\end{array}$ & $\begin{array}{l}-0.181 * * \\
(0.0877)\end{array}$ & $\begin{array}{l}-0.0350 \\
(0.0261)\end{array}$ & $\begin{array}{c}-0.132 \\
(0.0993)\end{array}$ \\
\hline $\begin{array}{l}\text { Cohorts 1980-1982 rel. to } \\
\text { untreated }\end{array}$ & $\begin{array}{l}-0.0377 * * * \\
(0.00897)\end{array}$ & $\begin{array}{l}-0.217^{* * *} \\
(0.0387)\end{array}$ & $\begin{array}{c}-0.352 * * * \\
(0.0875)\end{array}$ & $\begin{array}{c}-0.0676 * * \\
(0.0263)\end{array}$ & $\begin{array}{c}-0.373 * * * \\
(0.0980)\end{array}$ \\
\hline $\begin{array}{l}\text { Cohorts 1977-1979 rel. to } \\
\text { untreated }\end{array}$ & $\begin{array}{l}-0.0413^{* * *} \\
(0.00897)\end{array}$ & $\begin{array}{c}-0.290 * * * \\
(0.0430)\end{array}$ & $\begin{array}{c}-0.336 * * * \\
(0.0904)\end{array}$ & $\begin{array}{c}-0.126 * * * \\
(0.0285)\end{array}$ & $\begin{array}{c}-0.407 * * * \\
(0.0981)\end{array}$ \\
\hline $\begin{array}{l}\text { Untreated Cohorts (1972- } \\
\text { 1976) }\end{array}$ & $\begin{array}{l}0.0269 * * * \\
(0.00760)\end{array}$ & $\begin{array}{l}0.179 * * * \\
(0.0352)\end{array}$ & $\begin{array}{l}0.338 * * * \\
(0.0737)\end{array}$ & $\begin{array}{c}0.0412 \\
(0.0253)\end{array}$ & $\begin{array}{l}0.250 * * * \\
(0.0804)\end{array}$ \\
\hline Placebo test & Pass & Pass & Pass & Pass & Pass \\
\hline Specification & $\begin{array}{l}\text { Treatment } \\
\text { Windows }\end{array}$ & $\begin{array}{l}\text { Treatment } \\
\text { Windows }\end{array}$ & $\begin{array}{l}\text { Treatment } \\
\text { Windows }\end{array}$ & $\begin{array}{l}\text { Treatment } \\
\text { Windows }\end{array}$ & $\begin{array}{l}\text { Treatment } \\
\text { Windows }\end{array}$ \\
\hline Observations & $1,688,234$ & $1,688,234$ & $1,688,234$ & $1,688,234$ & $1,688,234$ \\
\hline R-squared & 0.186 & 0.186 & 0.186 & 0.186 & 0.186 \\
\hline
\end{tabular}

Notes: Robust standard errors in parentheses. Statistical significance at 1, 5 and $10 \%$ level is denoted by ***, **, *. The combination (choice $2 \mathrm{~km}$, competition $100 \mathrm{~km}$ ) not shown because of very different geographical range. For a complete list of included covariates see Table 3. The definition of the placebo tests is explained in Section 5. 
On the contrary, the effect of the nearest school facing a lot of competitive pressure is negative and significant for the older cohorts. However, it gets more positive for the youngest cohorts and, depending on the choice measure used, even reaches positive significance for the youngest cohorts. Again, all effects are economically small. One interpretation of these results is that the competitive pressure might at first have shaken up the system and caused disruptions ${ }^{52}$, resulting in a lower school quality, but that this effect faded out as schools learned to adjust to the new situation. Another possibility is that the growing school age cohorts the years after the choice reforms were implemented mitigated the competitive pressure due to the entry of the private schools.

\subsection{Effects of time-varying post-reform measures of choice}

In our empirical analysis so far, we examined the impacts of choice and competition based on the pre-determined location of schools and individuals, since these were plausibly not affected by the choice reform.

It is likely that the reform itself started an endogenous process of school development, where some schools, particularly non-public schools, started up, and others were closed. This process may also have affected families' choices of where to live. In order to shed light on these processes, in this section we will study the relation between the pre-determined and the actual availability of schools, and we will re-run the baseline regression equation using the actual locations of residence and schools to measure choice and competition, instead of the pre-reform measures.

We will label definitions of choice based on the location of schools and individuals before the reform as pre-reform measures, whereas the post-reform measures (also called actual measures in the below sections) will refer to the location at the time when a student potentially chooses school, i.e. when starting grade 7 , in our analysis. For example, for students entering first grade in 1995, the post-reform measure will be calculated based on the locations in 1995, for those entering in 1996, the locations in 1996 will be used, etcetera.

\footnotetext{
${ }^{52}$ See Waslander et al. (2010) for a related case study on Stockholm.
} 


\subsubsection{Number of schools before and after the reform}

We start by exploring how the pre-reform and post-reform choice measures differ. The aim is to achieve a better understanding of how the pre-reform situation is related to the choice situation that evolves after the reform. Specifically, we will test if the change over time in the number of available schools, as measured by our choice-index, is correlated with the choice-index at the time the reform was implemented.

In order to do so, we take the difference between the post-reform and the pre-reform choice measures, and regress this difference on the pre-reform choice measure and on a linear trend that is interacted with the pre-reform choice measure. ${ }^{53}$ This specification will show how the change in the number of available schools over time is correlated with the initial choice situation that a student faced in 1991. In a second specification we add all control variables used in the main estimations and, additionally, the parishaverage $9^{\text {th }}$ grade percentile rank of cohort 1972, i.e. the first cohort for which we have information on educational outcomes and who finished $9^{\text {th }}$ grade in 1988 , four years before the choice reform. ${ }^{54}$ The idea of controlling for the latter variable is to explore whether the difference in the number of schools is correlated with previous educational outcomes. Keeping the notation used in Section 5, the estimation equation for the second specification, including all covariates, reads as follows:

(6) $c_{i}^{\text {post-reform }}-c_{i}^{\text {pre-reform }}=\alpha \cdot c_{i}^{\text {pre-reform }}+\beta \cdot c_{i}^{\text {pre-reform }} \cdot t_{i}+\gamma_{\text {cohort }}+\lambda_{\text {municipality }}+\delta \cdot X_{i}+u_{i}$

where $t_{i}=$ year of birth -1972 .

Table 15 shows the results of the estimations. We focus on the choice measure "number of schools within median commuting distance" and run separate regressions looking at all schools, only public schools, and only private schools, respectively. ${ }^{55}$ Note that the difference between the pre- and post-reform measures is due both to schools opening up and closing down, and to students moving. For the private schools, the difference between the pre-reform and the post-reform measure reflects the growth

\footnotetext{
53 The estimations include only data on individuals that started grade seven in or after the year 1992, i.e. birth cohorts 1979-1990, as these are the ones for which we use the pre-reform measures in the main estimations.

${ }^{54}$ As in the previous estimations, all control variables are again based on the pre-reform location of residence.

${ }^{55}$ Note that we always use the median commuting distance before the reform, i.e. the range of the geographical area considered is not permitted to be endogenously changed by the reform.
} 
of the private school sector after the reform, as there were almost no private schools in Sweden before the reform.

Table 15: Relation between pre-reform and post-reform number of schools

Outcome: Difference between number of schools before and after the reform Choice Measure: Number of schools within median commuting distance

Grade Level: 7-9

\begin{tabular}{|c|c|c|c|c|c|c|}
\hline & All schools & All schools & $\begin{array}{l}\text { Public } \\
\text { schools }\end{array}$ & $\begin{array}{l}\text { Public } \\
\text { schools }\end{array}$ & $\begin{array}{l}\text { Private } \\
\text { schools }\end{array}$ & $\begin{array}{l}\text { Private } \\
\text { schools }\end{array}$ \\
\hline \multicolumn{7}{|l|}{ Coefficients } \\
\hline Pre-reform no. of schools & $\begin{array}{c}-0.534 * * * \\
(0.0423)\end{array}$ & $\begin{array}{l}-1.012 * * * \\
(0.0466)\end{array}$ & $\begin{array}{l}-0.161^{* * *} \\
(0.0245)\end{array}$ & $\begin{array}{c}-0.495^{* * *} \\
(0.0339)\end{array}$ & $\begin{array}{c}-0.373^{* * *} \\
(0.0261)\end{array}$ & $\begin{array}{c}-0.517 * * * \\
(0.0260)\end{array}$ \\
\hline $\begin{array}{l}\text { Pre-reform no. of schools } \\
\times \text { Linear trend (cohort- } \\
1972 \text { ) }\end{array}$ & $\begin{array}{l}0.0600^{* * *} \\
(0.00432)\end{array}$ & $\begin{array}{l}0.0655^{* * *} \\
(0.00387)\end{array}$ & $\begin{array}{l}0.0174 * * * \\
(0.00282)\end{array}$ & $\begin{array}{l}0.0195^{* * *} \\
(0.00282)\end{array}$ & $\begin{array}{l}0.0427 * * * \\
(0.00218)\end{array}$ & $\begin{array}{r}0.0461^{* * * *} \\
(0.00192)\end{array}$ \\
\hline $\begin{array}{l}\text { Pre-reform parish average } \\
\text { percentile rank GPA } 9\end{array}$ & & $\begin{array}{l}-0.00667 \\
(0.00762)\end{array}$ & & $\begin{array}{l}-0.00491 \\
(0.00423)\end{array}$ & & $\begin{array}{l}-0.00176 \\
(0.00475)\end{array}$ \\
\hline Constant & $\begin{array}{c}0.893 * * * \\
(0.172)\end{array}$ & $\begin{array}{c}91.71 * * * \\
(12.50)\end{array}$ & $\begin{array}{c}0.754 * * * \\
(0.134)\end{array}$ & $\begin{array}{c}70.34 * * * \\
(9.533)\end{array}$ & $\begin{array}{l}0.139 * * \\
(0.0552)\end{array}$ & $\begin{array}{c}21.37 * * * \\
(3.188)\end{array}$ \\
\hline \multicolumn{7}{|l|}{ Marginal Effects† } \\
\hline Cohorts 1988-1990 & $\begin{array}{l}0.486 * * * \\
(0.0346)\end{array}$ & $\begin{array}{l}0.102 * * \\
(0.0410)\end{array}$ & $\begin{array}{l}0.134 * * * \\
(0.0267)\end{array}$ & $\begin{array}{c}-0.164 * * * \\
(0.0324)\end{array}$ & $\begin{array}{l}0.353 * * * \\
(0.0158)\end{array}$ & $\begin{array}{c}0.265^{* * *} \\
(0.0168)\end{array}$ \\
\hline Cohorts 1985-1987 & $\begin{array}{l}0.306 * * * \\
(0.0227)\end{array}$ & $\begin{array}{c}-0.0948 * * * \\
(0.0337)\end{array}$ & $\begin{array}{c}0.0815 * * * \\
(0.0189)\end{array}$ & $\begin{array}{c}-0.222^{* * *} \\
(0.0270)\end{array}$ & $\begin{array}{l}0.225^{* * * *} \\
(0.0112)\end{array}$ & $\begin{array}{l}0.127 * * * \\
(0.0141)\end{array}$ \\
\hline Cohorts 1982-1984 & $\begin{array}{c}0.126 * * * \\
(0.0132)\end{array}$ & $\begin{array}{c}-0.291 * * * \\
(0.0294)\end{array}$ & $\begin{array}{c}0.0294 * * \\
(0.0121)\end{array}$ & $\begin{array}{c}-0.281^{* * *} \\
(0.0236)\end{array}$ & $\begin{array}{c}0.0967 * * * \\
(0.00940)\end{array}$ & $\begin{array}{l}-0.0108 \\
(0.0133)\end{array}$ \\
\hline Cohorts 1979-1981 & $\begin{array}{c}-0.0539 * * * \\
(0.0129)\end{array}$ & $\begin{array}{c}-0.488 * * * \\
(0.0294)\end{array}$ & $\begin{array}{l}-0.0226 * * \\
(0.00893)\end{array}$ & $\begin{array}{c}-0.339 * * * \\
(0.0230)\end{array}$ & $\begin{array}{c}-0.0313 * * * \\
(0.0117)\end{array}$ & $\begin{array}{c}-0.149 * * * \\
(0.0150)\end{array}$ \\
\hline Cohort dummies & No & Yes & No & Yes & No & Yes \\
\hline Municipality dummies & No & Yes & No & Yes & No & Yes \\
\hline Full set of covariates & No & Yes & No & Yes & No & Yes \\
\hline Observations & $1,214,130$ & $1,117,774$ & $1,214,130$ & $1,117,774$ & $1,214,130$ & $1,117,774$ \\
\hline R-squared & 0.207 & 0.503 & 0.035 & 0.416 & 0.524 & 0.640 \\
\hline
\end{tabular}

Notes: Robust standard errors in parentheses. Statistical significance at 1, 5 and $10 \%$ level is denoted by $* * *, * *, *$. For a list on the full set of covariates see Table 3.

${ }^{+}$The marginal effects are averages of the cohort specific marginal effects of all cohorts in the respective treatment window. A cohort specific marginal effect is computed by adding the base coefficient to the product of the interaction coefficient and the value of the trend variable for the specific cohort.

The upper panel of Table 15 shows the coefficients on the pre-reform choice measure and its interaction with a trend. The resulting marginal effects for each treatment window cohort group are displayed in the lower panel. Note that these are averages of the cohort specific marginal effects of all cohorts in the respective treatment window. A cohort specific marginal effect is computed by adding the base coefficient to the product 
of the interaction coefficient and the value of the trend variable for the specific cohort. Columns two, four and six include additional covariates.

Focusing first on the marginal effects when no additional covariates are included, that is columns one, three and five in the lower panel, we see that having more schools around before the reform is associated with a more positive difference between the actual and the pre-reform number of overall, public and private schools for all cohorts except for those in the first treatment window, cohorts 1979-1981. This holds both when we pool the public and private schools, and when we run separate regressions.

However, including all covariates, we find that this relationship reverses for all cohorts, except for those in the last treatment window, when we pool the private and public schools in column two. Column four shows that negative marginal effects are estimated for all cohorts when we use only the public schools, while for the private schools, in column six, the marginal effects are negative for the two first cohort treatment windows, and then turn positive. This indicates that, for cohorts born between 1979 and 1987, conditional on all included covariates, the difference between the number of public and private schools after the reform and the number of public schools nearby in 1991, is smaller the more schools were around in 1991. This pattern stems mainly from the public schools: for the private schools, the relation is negative only for students starting $7^{\text {th }}$ grade in the first years after the reform. Starting from cohort 1985, we see again that having more schools nearby before is related to a larger increase in the number of private schools, and for cohorts 1988-1990, this also holds for the aggregate of public and private schools. Since these effects are a combination of schools opening and closing, and families moving homes, it is hard to interpret this in terms of school openings only, especially for the public schools ${ }^{56}$. However, an important fact to note

\footnotetext{
${ }^{56}$ To illustrate this, imagine for example a student who will start $7^{\text {th }}$ grade in the year 2000. In the year 1991, when we measure the pre-reform choice value, her parents might not have thought much about schooling yet, and may thus live in a region that has relatively few schools. By 2000, they may have moved to a region that allows their child to attend a school nearby. So we see an increase between the post- and the pre-reform measure. Another family in the same situation may be living in an area with many schools since long, so once their child starts school they do not need to move, and the difference between their pre-reform measure and the actual measure is zero, if no school has opened up or closed. So without any new schools opening up, we see that the difference between the actual measure and the pre-reform measure is negatively related to having many schools nearby before the reform. The second mechanism is the opening up of new schools. Ignoring any moves by families, having more schools nearby before the reform may mean that fewer schools open up in the same area after the reform, and there may even be more potential
} 
for the interpretation of our results is that the pre-reform measures of choice and competition are positively correlated with their post-reform counterparts in levels, and that having a higher pre-reform choice measure is positively related to the increase in the number of available private schools. This means that our pre-reform measure also captures the opening up of private schools after the reform, and that this dynamic process is thus included in our estimated effects.

Table 15 also reports the effect of the parish level average of the percentile rank in $9^{\text {th }}$ grade GPA of students born in 1972 (that is the class finishing $9^{\text {th }}$ grade in 1988), see the upper panel. This is always negative, though very small and statistically insignificant. This suggests that, conditional on parental and parish level characteristics such as income and education, on average private schools do not seem to sort into areas based on student grades. ${ }^{57}$

\subsubsection{Effects of choice when using the actual choice opportunities at 7th grade}

The previous section indicated that, as expected, the choice-index changes somewhat over time. In this section we therefore, for the sake of comparison, show the results of our main regression specification when we, instead of using the pre-reform measures, use the actual measures of choice (that is, measured at the time a student starts grade 7). There are a few issues that are worth to discuss before we turn to the results.

First, using the actual measures instead of the pre-reform counterparts means making a different set of assumptions, and also gives estimates that have a different interpretation. In particular, under the assumption that schools opened up randomly and parents did not move in reaction to the reform, using the actual choice-measure would estimate the pure effect of having more schools to choose from when entering grade 7 . This is a different effect from the one we estimate when we use the pre-reform measures, which includes all dynamic processes (including subsequent changes in the number of schools and residential location) associated with having many schools nearby at the time of the implementation of the reform.

\footnotetext{
for schools closing down. Again, this results in a negative correlation between the difference in the actual and the prereform choice measure and the number of schools nearby before the reform.

${ }^{57}$ Under the assumption that student grades is a valid indicator of ability, this can be generalized to indicating that the choice of location of private schools is not endogenous with respect to student ability.
} 
Second, however, as discussed in Section 5, there are reasons to believe that the assumptions stated above, that schools opened up randomly and parents did not move in reaction to the reform, might not hold. For example, schools that work for profit will probably have chosen the location of business such as to maximize profits, and parents who are concerned about their children's outcomes are more likely to move to areas that will increase the chances of educational success. By including our extensive set of control variables on regional and individual characteristics we may be able to reduce this endogeneity problem to some extent, but we cannot be certain that it is fully eliminated.

Third, another caveat is that, when we measure the number of schools contemporaneously, we do not know at which point we are in the equilibrium process of schools opening up and closing in response to parental/student demand. It could for example be that having more schools nearby in period $t$ leads to the bad schools closing down or being overtaken in period $t+1$, which leads to having only few schools nearby in period $t+2$. If the market worked perfectly, the schools remaining would be the very good schools, which would lead us to observe a positive association between few schools (low measures of choice) and good outcomes. A low choice index in $t+2$ could hence actually be the result of a highly competitive process. Thus, estimating the effect of more choice and competition in a dynamically evolving environment poses identifycation problems of a new nature.

Keeping this in mind, it is still interesting to analyse the association between the number of public and private schools nearby and student outcomes at the time when a choice is made. The first column of Table 16 presents the effect of the actual number of schools in the median commuting distance near a student's home offering grades 7-9 on the percentile rank in GPA 9 (estimated according to Equation (4)). Rather surprisingly, we see that having more schools nearby at the time of making a decision has no significant positive effect for most cohorts, but even a small negative one for birth cohorts 1982-1984. Column three shows that using the number of schools within $2 \mathrm{~km}$ as a choice measure leads to similar conclusions. 
Table 16: Effects of actual choice measures on percentile rank in GPA 9

Outcome: Percentile rank grades 9

Choice Measure: Number of schools within radius...

Grade Level: $7-9$

\begin{tabular}{|c|c|c|c|c|}
\hline & \multicolumn{2}{|c|}{$\begin{array}{l}\text { Radius: median commuting } \\
\text { distance }\end{array}$} & \multicolumn{2}{|l|}{ Radius: 2km } \\
\hline & All schools & $\begin{array}{c}\text { Public and } \\
\text { private separate }\end{array}$ & All schools & $\begin{array}{c}\text { Public and } \\
\text { private separate }\end{array}$ \\
\hline $\begin{array}{l}\text { Cohorts 1988-1990 rel. to } \\
\text { untreated }\end{array}$ & $\begin{array}{c}0.0137 \\
(0.0185)\end{array}$ & & $\begin{array}{l}-0.0431 \\
(0.0489)\end{array}$ & \\
\hline $\begin{array}{l}\text { Cohorts 1985-1987 rel. to } \\
\text { untreated }\end{array}$ & $\begin{array}{l}-0.00643 \\
(0.0187)\end{array}$ & & $\begin{array}{l}-0.0916 * \\
(0.0519)\end{array}$ & \\
\hline $\begin{array}{l}\text { Cohorts 1982-1984 rel. to } \\
\text { untreated }\end{array}$ & $\begin{array}{c}-0.0387 * * \\
(0.0185)\end{array}$ & & $\begin{array}{l}-0.124 * * \\
(0.0533)\end{array}$ & \\
\hline $\begin{array}{l}\text { Cohorts 1979-1981 rel. to } \\
\text { untreated }\end{array}$ & $\begin{array}{l}-0.0145 \\
(0.0188)\end{array}$ & & $\begin{array}{l}-0.0417 \\
(0.0584)\end{array}$ & \\
\hline $\begin{array}{l}\text { Cohorts 1977-1978 rel. to } \\
\text { untreated }\end{array}$ & $\begin{array}{l}-0.0184 \\
(0.0215)\end{array}$ & & $\begin{array}{l}-0.0596 \\
(0.0624)\end{array}$ & \\
\hline $\begin{array}{l}\text { Untreated Cohorts } \\
(1972-1976)\end{array}$ & $\begin{array}{c}0.0190 \\
(0.0180)\end{array}$ & & $\begin{array}{l}0.205^{* * *} \\
(0.0406)\end{array}$ & \\
\hline Public choice & & & & \\
\hline $\begin{array}{l}\text { Cohorts } 1988-1990 \text { rel. to } \\
\text { untreated }\end{array}$ & & $\begin{array}{l}-0.0127 \\
(0.0264)\end{array}$ & & $\begin{array}{l}-0.192^{* * *} \\
(0.0613)\end{array}$ \\
\hline $\begin{array}{l}\text { Cohorts 1985-1987 rel. to } \\
\text { untreated }\end{array}$ & & $\begin{array}{l}-0.0230 \\
(0.0263)\end{array}$ & & $\begin{array}{c}-0.212 * * * \\
(0.0633)\end{array}$ \\
\hline $\begin{array}{l}\text { Cohorts 1982-1984 rel. to } \\
\text { untreated }\end{array}$ & & $\begin{array}{l}-0.0456 * \\
(0.0252)\end{array}$ & & $\begin{array}{l}-0.160 * * \\
(0.0657)\end{array}$ \\
\hline $\begin{array}{l}\text { Cohorts 1979-1981 rel. to } \\
\text { untreated }\end{array}$ & & $\begin{array}{c}0.0388 \\
(0.0245)\end{array}$ & & $\begin{array}{l}-0.0129 \\
(0.0636)\end{array}$ \\
\hline $\begin{array}{l}\text { Cohorts 1977-1978 rel. to } \\
\text { untreated }\end{array}$ & & $\begin{array}{l}-0.0255 \\
(0.0310)\end{array}$ & & $\begin{array}{l}-0.0661 \\
(0.0736)\end{array}$ \\
\hline $\begin{array}{l}\text { Untreated Cohorts (1972- } \\
\text { 1976) }\end{array}$ & & $\begin{array}{l}-0.0243 \\
(0.0230)\end{array}$ & & $\begin{array}{c}0.197 * * * \\
(0.0442)\end{array}$ \\
\hline Private choice & & & & \\
\hline $\begin{array}{l}\text { Cohorts } 1988-1990 \text { rel. to } \\
\text { untreated }\end{array}$ & & $\begin{array}{c}0.0303 \\
(0.0700)\end{array}$ & & $\begin{array}{c}0.273 \\
(0.175)\end{array}$ \\
\hline $\begin{array}{l}\text { Cohorts 1985-1987 rel. to } \\
\text { untreated }\end{array}$ & & $\begin{array}{c}0.0746 \\
(0.0753)\end{array}$ & & $\begin{array}{c}0.291 \\
(0.189)\end{array}$ \\
\hline $\begin{array}{l}\text { Cohorts 1982-1984 rel. to } \\
\text { untreated }\end{array}$ & & $\begin{array}{c}0.0634 \\
(0.0784)\end{array}$ & & $\begin{array}{l}0.0200 \\
(0.200)\end{array}$ \\
\hline $\begin{array}{l}\text { Cohorts 1979-1981 rel. to } \\
\text { untreated }\end{array}$ & & $\begin{array}{l}-0.206^{* *} \\
(0.0881)\end{array}$ & & $\begin{array}{l}-0.151 \\
(0.236)\end{array}$ \\
\hline $\begin{array}{l}\text { Cohorts 1977-1978 rel. to } \\
\text { untreated }\end{array}$ & & $\begin{array}{l}0.0328 \\
(0.102)\end{array}$ & & $\begin{array}{l}-0.0284 \\
(0.245)\end{array}$ \\
\hline $\begin{array}{l}\text { Untreated Cohorts } \\
(1972-1976)\end{array}$ & & $\begin{array}{l}0.138 * * \\
(0.0653)\end{array}$ & & $\begin{array}{c}0.171 \\
(0.162)\end{array}$ \\
\hline Constant & $19.86 * * *$ & $20.63 * * *$ & $19.04 * * *$ & $20.47 * * *$ \\
\hline
\end{tabular}


Outcome: Percentile rank grades 9

Choice Measure: Number of schools within radius...

Grade Level: 7-9

\begin{tabular}{|c|c|c|c|c|}
\hline & \multicolumn{2}{|c|}{$\begin{array}{l}\text { Radius: median commuting } \\
\text { distance }\end{array}$} & \multicolumn{2}{|l|}{ Radius: 2km } \\
\hline & All schools & $\begin{array}{c}\text { Public and } \\
\text { private separate }\end{array}$ & All schools & $\begin{array}{c}\text { Public and } \\
\text { private separate }\end{array}$ \\
\hline & (3.176) & (3.134) & (3.157) & (3.148) \\
\hline Placebo test & Pass & Pass & Pass & Pass \\
\hline Pre-reform trend & No & No & No & No \\
\hline Specification & $\begin{array}{l}\text { Treatment } \\
\text { Windows }\end{array}$ & $\begin{array}{l}\text { Treatment } \\
\text { Windows }\end{array}$ & $\begin{array}{l}\text { Treatment } \\
\text { Windows }\end{array}$ & $\begin{array}{l}\text { Treatment } \\
\text { Windows }\end{array}$ \\
\hline Observations & $1,743,753$ & $1,743,753$ & $1,743,753$ & $1,743,753$ \\
\hline R-squared & 0.186 & 0.186 & 0.186 & 0.186 \\
\hline
\end{tabular}

Notes: Robust standard errors in parentheses. Statistical significance at 1, 5 and $10 \%$ level is denoted by ***, **, * For a complete list of included covariates see Table 3. The definition of the placebo tests is explained in Section 5.

In order to obtain a better understanding of this result, we calculated the choice measures for public and private schools separately. Column two and four show results from estimations including these two measures and their interaction terms with treatment window dummies. For the radius "median commuting distance", the coefficients on the effect of having more public schools to choose from are always small and negative but only statistically significant at the 90\% level for cohorts 1982-1984. However, using a $2 \mathrm{~km}$ radius instead we find small but significant negative effects of having more public schools nearby on the percentile rank in marks. At the same time, the point estimates on the number of private schools are mostly positive, but again very small, economically zero, and almost never statistically significant.

Table 17 shows the results for the outcome "cognitive skills at age 18” which is estimated for men only. Also in this case the specifications using the choice measure based on the median commuting distance yields very small, basically zero, marginal effects. Using instead the $2 \mathrm{~km}$-choice radius yields somewhat larger effects, which are negative for the private but positive for the public schools. 
Table 17: Effects of actual choice measures on cognitive score

Outcome: Cognitive skills

Choice Measure: Number of schools within radius...

Grade Level: $7-9$

\begin{tabular}{lllll}
\multicolumn{2}{c}{ Radius: median commuting distance } & & Radius: $2 \mathrm{~km}$ & \\
\cline { 1 - 1 } All Schools & $\begin{array}{l}\text { Public and } \\
\text { private separate }\end{array}$ & All schools & $\begin{array}{l}\text { Public and } \\
\text { private separate }\end{array}$
\end{tabular}

\begin{tabular}{|c|c|c|c|c|}
\hline $\begin{array}{l}\text { Cohorts 1985-1987 rel. to } \\
\text { untreated }\end{array}$ & $\begin{array}{l}-0.000212 \\
(0.00160)\end{array}$ & & $\begin{array}{l}0.00878 * \\
(0.00478)\end{array}$ & \\
\hline $\begin{array}{l}\text { Cohorts 1982-1984 rel. to } \\
\text { untreated }\end{array}$ & $\begin{array}{l}-0.000881 \\
(0.00159)\end{array}$ & & $\begin{array}{c}0.00563 \\
(0.00489)\end{array}$ & \\
\hline $\begin{array}{l}\text { Cohorts 1979-1981 rel. to } \\
\text { untreated }\end{array}$ & $\begin{array}{l}-0.00148 \\
(0.00158)\end{array}$ & & $\begin{array}{c}0.00814 \\
(0.00514)\end{array}$ & \\
\hline $\begin{array}{l}\text { Cohorts 1977-1978 rel. to } \\
\text { untreated }\end{array}$ & $\begin{array}{c}0.00262 \\
(0.00205)\end{array}$ & & $\begin{array}{l}0.0128 * * \\
(0.00609)\end{array}$ & \\
\hline Untreated Cohorts (1972-1976) & $\begin{array}{c}0.00109 \\
(0.00159)\end{array}$ & & $\begin{array}{c}-0.0116 * * * \\
(0.00375)\end{array}$ & \\
\hline \multicolumn{5}{|l|}{ Public choice } \\
\hline $\begin{array}{l}\text { Cohorts 1985-1987 rel. to } \\
\text { untreated }\end{array}$ & & $\begin{array}{c}0.00325 \\
(0.00228)\end{array}$ & & $\begin{array}{l}0.0157 * * * \\
(0.00573)\end{array}$ \\
\hline $\begin{array}{l}\text { Cohorts 1982-1984 rel. to } \\
\text { untreated }\end{array}$ & & $\begin{array}{c}0.00449 * * \\
(0.00221)\end{array}$ & & $\begin{array}{c}0.0192 * * * \\
(0.00585)\end{array}$ \\
\hline $\begin{array}{l}\text { Cohorts 1979-1981 rel. to } \\
\text { untreated }\end{array}$ & & $\begin{array}{c}0.00191 \\
(0.00220)\end{array}$ & & $\begin{array}{l}0.0162 * * * \\
(0.00605)\end{array}$ \\
\hline $\begin{array}{l}\text { Cohorts 1977-1978 rel. to } \\
\text { untreated }\end{array}$ & & $\begin{array}{c}0.00281 \\
(0.00292)\end{array}$ & & $\begin{array}{l}0.0158^{* *} \\
(0.00708)\end{array}$ \\
\hline Untreated Cohorts (1972-1976) & & $\begin{array}{l}-0.00207 \\
(0.00208)\end{array}$ & & $\begin{array}{c}-0.0187^{* * * *} \\
(0.00420)\end{array}$ \\
\hline \multicolumn{5}{|l|}{ Private choice } \\
\hline $\begin{array}{l}\text { Cohorts 1985-1987 rel. to } \\
\text { untreated }\end{array}$ & & $\begin{array}{l}-0.0130 * * \\
(0.00590)\end{array}$ & & $\begin{array}{c}-0.0497 * * * \\
(0.0164)\end{array}$ \\
\hline $\begin{array}{l}\text { Cohorts 1982-1984 rel. to } \\
\text { untreated }\end{array}$ & & $\begin{array}{c}-0.0224 * * * \\
(0.00610)\end{array}$ & & $\begin{array}{c}-0.0704 * * * \\
(0.0174)\end{array}$ \\
\hline $\begin{array}{l}\text { Cohorts 1979-1981 rel. to } \\
\text { untreated }\end{array}$ & & $\begin{array}{l}-0.0144^{* *} \\
(0.00668)\end{array}$ & & $\begin{array}{c}-0.0488 * * \\
(0.0196)\end{array}$ \\
\hline $\begin{array}{l}\text { Cohorts 1977-1978 rel. to } \\
\text { untreated }\end{array}$ & & $\begin{array}{c}0.00230 \\
(0.00839)\end{array}$ & & $\begin{array}{l}-0.0140 \\
(0.0239)\end{array}$ \\
\hline Untreated Cohorts (1972-1976) & & $\begin{array}{c}0.0133 * * * \\
(0.00493)\end{array}$ & & $\begin{array}{c}0.0462 * * * \\
(0.0147)\end{array}$ \\
\hline Constant & $\begin{array}{c}2.518 * * * \\
(0.267)\end{array}$ & $\begin{array}{c}2.457^{* * *} \\
(0.269)\end{array}$ & $\begin{array}{c}2.449 * * * \\
(0.267)\end{array}$ & $\begin{array}{c}2.360 * * * \\
(0.269)\end{array}$ \\
\hline Placebo test & Pass & Pass & Pass & Pass \\
\hline Pre-reform trend & No & $\mathrm{Yes}^{\dagger}$ & No & No \\
\hline Specification & $\begin{array}{l}\text { Treatment } \\
\text { Windows }\end{array}$ & $\begin{array}{l}\text { Treatment } \\
\text { Windows }\end{array}$ & $\begin{array}{l}\text { Treatment } \\
\text { Window }\end{array}$ & $\begin{array}{l}\text { Treatment } \\
\text { Window }\end{array}$ \\
\hline Observations & 615,225 & 615,225 & 615,225 & 615,225 \\
\hline R-squared & 0.150 & 0.150 & 0.150 & 0.150 \\
\hline
\end{tabular}

Notes: Robust standard errors in parentheses. Statistical significance at 1, 5 and $10 \%$ level is denoted by ***, **, *. For a complete list of included covariates see Table 3. The definition of the placebo tests is explained in Section 5. The mean of the cognitive score is 5 , the standard deviation 1.9 . 
In sum, using the actual measures of choice, measured at the time the student enters $7^{\text {th }}$ grade, yields small and often insignificant marginal effects, especially when we use the choice measure based on the commuting distance. For the specification with the $2 \mathrm{~km}$ choice radius, the estimated effects shown in the table are a bit larger, and vary in sign between the outcomes and between private and public schools. However, given that the standard deviation for this choice index is only around two, the effects in terms of a one standard deviation increase are still very small.

\section{Conclusion}

In this paper, we analyse the average effects of choice and competition caused by the introduction of the Swedish school choice reform in 1992. We identify the intention-totreat effect by assessing whether having more choice opportunities at the outset of the reform has affected average student outcomes in the short- and long-run. We find that more school choice, measured by having more schools nearby right before the reform, has small positive effects on marks at the end of compulsory schooling, and, depending on the choice measure used, very small effects on cognitive skills at age 18. We also analyse longer term outcomes such as university education, employment, criminal activity and health, and sometimes find small, but no economically relevant positive effects in these dimensions on average. Our estimates of the school choice effects are to be interpreted relative to a system with Tiebout choice, i.e. where the only possibility to choose is by moving residence, which was in place in Sweden before the reform and is still in place in many countries.

Previous studies on the Swedish reform, have reported effects of an increase in the private school share by 10 percentage points on the percentile rank in grades at the end of ninth grade in the range of 0 to 20 percent of a standard deviation, depending on the identification strategy and definition of the outcome variable. Our results fall close to the studies that estimate modest effects, such as Böhlmark and Lindahl (2012), and we find considerably smaller effects than for example Sandström and Bergström (2005). However, it is not surprising that we may arrive at a different conclusion than some of the previous studies, as these have looked specifically at effects of competition by private schools while this study focuses on choice and competition among public 
schools. Moreover, in this paper, we do not identify the direct effect but the intentionto-treat effect of the reform, which we believe to be relevant as it includes the dynamic processes that are triggered by the introduction of the reform and related to the initial choice setting. 


\section{References}

Ahlin, Å (2003), ”Does school competition matter? Effects of a large-scale school choice reform on student performance”, Working Paper 2003:2, Department of Economic, Uppsala University.

Ahlin, A \& E Mörk (2008), "Effects of decentralization on school resources", Economics of Education Review, vol 27, pp. 276-284.

Ammermueller, A and J Pischke (2009), "Peer effects in European primary schools: Evidence from the Progress in International Reading Literacy Study”, Journal of Labor Economics, 27(3), 315-348, 2009.

Angrist, J and K Lang (2004) "Does school integration generate peer effects? Evidence from Boston’s Metro program.” American Economic Review, 94(5), pp.1613-1634.

Bettinger, E (2011) “Educational vouchers in international contexts”, in: Handbook of the Economics of Education, Volume 4 (Ed. Hanushek, E, Machin, S and L Woessmann), Elsevier, p. 551-572.

Björklund, A, Edin, P, Fredriksson, P and A Krueger (2004), "Education, equality and efficiency - An analysis of Swedish school reforms during the 1990s”, IFAU Report 2004:1.

Björklund, A, Clark, M A, Edin, P-A, Fredriksson, P and A Krueger (2005), The Education Market Comes to Sweden. An Evaluation of Sweden's Surprising School Reforms, (Ed. Björklund, A.), Russel Sage Foundation, New York.

Burgess, S, Greaves, E, Vignoles, A and D Wilson (2009), "What Parents Want: School preferences and school choice”, CMPO Working Paper 09/222.

Böhlmark, A, and M Lindahl (2007), “The Impact of School Choice on Pupil Achievement, Segregation and Costs: Swedish Evidence”, IZA DP No. 2786

Böhlmark, A and M Lindahl (2012), "Independent schools and long-run educational outcomes: Evidence from Sweden's large scale voucher reform”, IZA DP No. 6683.

Epple, D and R E Romano, (1998), “Competition between Private and Public Schools, Vouchers and Peer Effects. The American Economic Review, 88(1), pp.33-62. 
Gibbons, S, Machin, S and O Silva (2008) "Choice, Competition and Pupil Achievement”, Journal of the European Economic Association, 6(4), pp. 912-947.

Grönqvist, E, Öckert, B and J Vlachos (2010) ”The intergenerational transmission of cognitive and non-cognitive abilities”, IFAU Working Paper 2010:12.

Hensvik, L (2012), “Competition, Wages and Teacher Sorting: Lessons Learned from a Voucher Reform”, The Economic Journal, Volume 122(561), pages 799-824.

Hanushek, E (1986), “The Economics of Schooling: Production and Efficiency in Public Schools”, Journal of Economic Literature, vol 24(3), pp.1141-1177.

Hanushek, E, Kain, J, Markman, J and S Rivkin (2002), "Does peer ability affect student achievement?” Journal of Applied Econometrics, 18, pp. 527-544.

Himmler, O (2009), “The Effects of School Competition on Academic Achievement and Grading Standards”, CESifo Working Paper Series No. 2676.

Hoxby, C (2000a), "Does competition among public schools benefit students and taxpayers?”, The American Economic Review, vol 90, pp. 1209-1238.

Hoxby, C (2000b), "Peer effects in the classroom: Learning from gender and race variation”, NBER Working Paper No. 7867.

Hoxby, C (2003), "School choice and school productivity. Could school choice be a tide that lifts all boats?”, in: The Economics of School Choice (Ed. Hoxby, C), pp. 287342, National Bureau of Economic Research, Inc.

Hoxby, C (2007), "Does competition among public schools benefit students and taxpayers? Reply”, The American Economic Review, vol 97, pp. 2038-2055.

Hsieh, C and M Urquiola (2006), "The effects of generalized school choice on achievement and stratification: Evidence from Chile’s voucher program”, Journal of Public Economics, vol 90, pp. 1477-1503.

Lavy, V and A Schlosser (2007), "Mechanisms and Impacts of Gender Peer Effects at School”, NBER Working Paper No. 13292. 
Lefgren, L (2004), “Educational peer effects and the Chicago public schools”, Journal of Urban Economics, 56(2), pp. 169-191.

Lindqvist, E and R Vestman (2011), "The Labour Market Returns to Cognitive and Noncognitive Ability: Evidence from the Swedish Enlistment," American Economic Journal: Applied Economics, vol. 3(1), pp. 101-28.

Noailly, J, Vujić, S and A Aouragh (2009), “The effects of competition on the quality of primary schools in the Netherlands”, CPB Discussion Paper No 120.

Rothstein, J (2007), “Does competition among public schools benefit students and taxpayers? Comment”, The American Economic Review, vol 97, pp. 2026-2037.

Sacerdote, B (2001), "Peer effects with random assignment: Results from Dartmouth roommates”, Quarterly Journal of Economics, 116(2), pp. 681-704.

Sandström, M and F Bergström (2005), “School vouchers in practise: competition won’t hurt you”, Journal of Public Economics, 89, pp. 351-380.

SOU 2007:28, ”Tydliga mål och kunskapskrav i grundskolan”, Regeringskansliet.

SOU 2007:101, ”Tydlig och öppen - förslag till en stärkt skolinspektion”, Regeringskansliet.

SOU 2008:8, “Bidrag på lika villkor”, Delbetänkande av Utredningen om villkoren för fristående skolor, Regeringskansliet.

The National Board of Education (Skolverket) (1996): "Att välja skola - effekter av valmöjlighet i grundskolan”, Report Nr 109.

The National Board of Education (Skolverket) (2003): "Valfrihet och dess effekter inom skolområdet”, Report 230.

The National Board of Education (Skolverket) (2005): "Skolor som alla andra? Med fristående skolor i systemet 1991-2004”, Report 271.

The National Board of Education (Skolverket) (2009): "Resursfördelning utifrån förutsättningar och behov? Report 330. 
Tiebout, C M (1956), “A Pure Theory of Local Expenditures”, Journal of Political Economy, Vol. 64(5), pp. $416-424$.

Vlachos, J (2010), ”Betygets värde. En analys av hur konkurrens påverkar betygssättningen vid svenska skolor.” Uppdragsforskningsrapport 2010:6, Konkurrensverket.

Von Greiff, C (2009), ”En skola med lika resurser?, En ESO-rapport om likvärdighet och resursfördelning”, ESO-rapport 2009:5.

Waslander, S, Pater, C and M van der Weide (2010), "Markets in education: An analytical review of empirical research on market mechanisms in education”, OECD Education Working Paper, No. 52.

Wikström C and M Wikström (2005), “Grade inflation and school competition: an empirical analysis based on the Swedish upper secondary schools”, Economics of Education Review, 24, pp. 309-322.

Zimmerman, D (2003), "Peer effects in academic outcomes: Evidence from a natural experiment.” Journal of Urban Economics, 85(1), pp. 9-23. 


\section{Appendix}

\section{School choice in practice}

For our study, it is important to know to what extent the reforms actually affected school choice as perceived by parents and students. This section aims to shed light on this issue.

The school choice reforms implemented in the early 1990s give quite some leeway for interpretation for the municipalities, who are in charge of providing compulsory schooling. Sweden's 290 municipalities vary a lot in size, from the small rural municipalities with a few thousand inhabitants and few schools, to the large densely populated urban municipalities with several hundred thousand inhabitants and many schools. It is hence likely that the practical implementation of the reforms differed between municipalities.

While information on the share of students opting for private schools is readily available, there exists relatively little information on the amount of active school choice taking place between public schools, especially for the early years after the reforms. Two surveys from the National Board of Education however provide information on the situation during school years 1994/95 and 2000/01. ${ }^{58}$

The 1994/95 survey, which contains information from the local authorities in ten large and predominantly urban municipalities ${ }^{59}$, reports that seven percent of the students switched to another school than the one they were assigned to before the start of the school year 1994/95. Out of these seven percent, two percent switched to a private school and five percent to a public school, and most of the changes took place between grade 3-4 and grade 6-7. In the country as a whole, only 1.5 percent of students chose another public school than the nearest one, while 1.8 percent of all students

\footnotetext{
${ }^{58}$ See The National Board of Education 1996; and 2003.

59 The surveyed municipalities are: Stockholm, Göteborg, Malmö, Uppsala, Linköping, Helsingborg, Södertälje, Botkyrka, Täby and Östersund. The study also contains case studies of 38 schools, out of which eight were private schools, in 12 municipalities.
} 
attended private schools. ${ }^{60}$ It hence seems that by the mid-nineties, a fairly small share of students chose another school than the one assigned.

By 2000/01, making an active school choice had become much more common: The report by the National Board of Education contains information from a survey to parents in six large urban municipalities where the scope for choice is deemed to be large ${ }^{61}$, and in a set of smaller and more rural municipalities. ${ }^{62}$ In the survey, 67 percent of parents in the "high-choice municipalities", and 34 percent of parents in the "low-choice municipalities”, state that they have made an active school choice. About two thirds of these, for both sets of municipalities, were however choices to the nearest public school, to which the student was assigned anyway. For the remaining third of those who had made an active choice, again for both sets of municipalities, choosing another public school than the nearest one was a bit more common than choosing a private school. A small share of parents, 1-3 percent, furthermore states that they made an active choice, but that they were not accepted due to lack of slots. It hence seems that the preferences of parents could be satisfied in the majority of cases. These figures suggest that by 2001, school choice was relatively common, but that there were large differences between municipalities. ${ }^{63}$

The 2003 report also collected information from the local authorities in all municipalities and town districts. ${ }^{64}$ According to the estimates of the local authorities, reported by the survey, in school year 2000/01, almost a quarter of all students lived in municipalities and town districts where five percent or more students attend another public school than the one in their catchment area, and five percent of students lived in municipalities and town districts where this share was 15 percent or higher. ${ }^{65}$ Regarding

\footnotetext{
${ }^{60}$ See p 57 The National Board of Education (1996) for public schools, and, for private schools, the website of The National Board of Education: Table 1.1.A on http://www.skolverket.se/statistik_och_analys/.

${ }^{61}$ These municipalities are large and urban, and were also covered in the 1996 report, see The National Board of Education (1996).

${ }^{62}$ The high-choice municipalities” are: Botkyrka, Stockholm, Södertälje, Uppsala, Helsingborg and Västerås. The survey info for the "low-choice municipalities" was gathered for a large set of municipalities - and they are not reported by name in the report.

63 Source: The National Board of Education (2003), pp. 48f.

${ }^{64}$ The larger municipalities are in general divided into town districts, which are responsible for some of the operations of the public sector.

${ }^{65}$ These figures were calculated using the raw data from the survey to the local authorities, which we were generously given access to from the National Board of Education. See also Table 3.8, The National Board of Education (2003)
} 
the private schools, the National Board of Education (2005) reports that the number of private compulsory schools nationwide grew from a bit over 200 in 1995 to over 500 in 2005. In 2002 the municipality-wise share of students that attended a private school was on average 5 percent, and was considerably higher, 12 percent, among the large cities. ${ }^{66}$

The 2003 survey from the National Board of Education also suggests that by 2000/01 a bit less than 30 percent of all municipalities and town districts ${ }^{67}$, predominantly in urban areas, have a policy to encourage parents/students to make an active school choice, and almost 40 percent provide parents/students with comprehensive information about the schools available in the municipality. About a quarter of the municipalities and town districts state that they provide school transport also to other schools than the nearest one.

About half of the parents in the 2003-survey also report that they had enough knowledge to make a well-informed choice.

We conclude that school choice has become increasingly common during the almost 20 years that have passed since the choice-reforms of the early 90s, and parents/students choose both to attend another public school than the nearest one and to attend private schools.

\section{Other education-related reforms}

The school choice reforms in the early 1990s were not the only education-related changes taking place in the 1990s, but they were part of a broad decentralization and choice-enhancing trend in the organization of the educational sector, as well as in the public sector in general. This section gives an overview of the other reforms that took place in the 1990s. This is useful both in order to provide a deeper understanding for the environment in which the school choice reforms took place, and in order to discuss other changes that took place in relation to our evaluation method.

One of the major education-related reforms of the 1990s, apart from the choicereforms, was the 1991 decentralization of the Swedish compulsory school system. ${ }^{68}$ The

\footnotetext{
${ }^{66}$ See the National Board of Education website for education statistics http://www.jmftal.artisan.se.

${ }^{67}$ The survey was directed to officials of the municipalities, or, in the case of larger municipalities which are divided into town districts, officials of the town districts.

${ }^{68}$ See Proposition 1990/91:18, SOU 2008:8 (p. 49f), and von Greiff (2009).
} 
reform changed the role of the central government from providing detailed regulation for the municipalities and schools to follow, to specifying broad goals on what the students should know at each completed level of education but by large leaving it to the schools and municipalities to decide how to achieve these goals. The evaluation of whether the schools meet the goals specified in the Law and National curriculum was, until the establishment of the Swedish Schools Inspectorate in 2008, by large left to the schools themselves. ${ }^{69} 70$

After the reform, municipalities and the individual schools were thus given considerable freedom to design the education, as long as they follow the basic curriculum. ${ }^{71}$ The reform also made teachers and headmasters, previously stateemployed, employees of the municipalities. ${ }^{72}$

Another part of the decentralization trend of the early 90s, was the replacement of the previous ear-marked central government grants ${ }^{73}$ with a system of general grants in 1991. At first, the grants were sector-specific, but in 1993, the grants were made completely general. Through the reform, the local politicians were hence given more decision power over the use of central government grants, both in terms of how much to allocate to education per se, and how much to allocate to different education related items.

In addition to the reforms described above, there is a couple of changes in the economic regulations for municipalities that took place during the 90 s merit mentioning. First, during 1991-1994, municipalities were prevented from raising the

\footnotetext{
${ }^{69}$ National standardized grade 9 tests were in addition made mandatory in 2003, and in 2009 for grades 3 and 5. Previously, standardized tests were available, but were up to the schools to use or not.

${ }^{70}$ See proposition 2008/09:87, SOU 2007:28, SOU 2007:101, and Björklund et al (2004).

${ }^{71}$ The school law (1985:1100) names the overall goals for the education system, as well as overall guidelines for the overall design of the education. It specifies the minimum requirements that the schools need to fulfill, such as how much time should be devoted to each subject. There is also a National curriculum (Lpo 1994), which specifies the broad values that the school system shall follow, as well as the (more specific) educational goals that the students shall reach.

72 At first, teacher pay negotiations remained centralized, but in 1995, the responsibility for the negotiations was transferred to the school level, and many schools adopted partly individualized wage schemes (Björklund et al (2005)).

${ }^{73}$ Until 1991, central government grants were earmarked for specific educational expenses. These grants were to cover for expenses that were directly related to actual teaching, with teacher salaries being the largest post. According to von Greiff (2009), the system for the allocation of the central government grants was very complex and nontransparent. The municipalities were responsible for financing, through income tax revenues, facilities, school food, school transport, school medical care and teaching material. In addition, they were free to add to the central government transfers for all posts except for the teacher salaries.
} 
local income tax, which constitutes their main source of income. Second, the rules for municipal budget balance have changed over time; the requirement for local budget discipline was relaxed in 1992, in order to become stricter again in $1997 .^{74}$

We can conclude that there is a set of other reforms that are related to the education sector during the period under study. In which sense are they relevant for our study?

First, the decentralization reforms gave the municipalities more say in how to organize compulsory education and how to allocate resources, while the tax rate cap and the stricter budget discipline are likely to have contributed to making the local education budget more sensitive to the local economic development. One can suspect that this may have given rise to larger variation in the education policy between the municipalities, but there is little guidance available from previous studies on whether this actually happened. ${ }^{75}$ Second, the decentralization reforms mean that schools have more freedom to choose pedagogical style and curriculum, and potentially also over the local budget process. ${ }^{76}$

\section{Moving patterns}

If Tiebout-migration (in terms of moving in order to get into a good school) was affected by the school choice reform, we would expect to see a different moving pattern after the reform for households with school aged children, and probably especially so for households in which the oldest child is about to enter school. In this section we therefore show descriptive statistics for households with children in different ages. Since the ability to afford to move near desirable schools was probably higher for highincome individuals, we would probably also expect larger changes in the moving patterns for these households, compared to low-income households. We therefore show shares that move separately for households in the upper and lower quartiles of the

\footnotetext{
${ }^{74}$ In 1992, the previous requirement of yearly balanced municipal budgets was changed to a more general statement that the local economy should follow "good economic housekeeping" (the Swedish term is: "god ekonomisk hushållning”). In 1997, the municipality law again was made stricter, stating that at the latest in 2000 all municipalities should follow a balanced budget over a 3-year period. ${ }^{74}$

${ }^{75}$ In fact, the only evaluation study that we are aware of, Ahlin and Mörk (2008), find some evidence of a less disperse distribution of education resources (measured as per student costs and teacher density) between municipalities after the decentralization reform, and find no correlation between the municipal tax base and per student school resources (excluding costs for facilities), neither before nor after the reforms.

${ }^{76}$ See p 21 in The National Board of Education (2009).
} 
income distribution, as well as for the households in the two mid-quartiles of the income distribution.

Unfortunately, we can only observe the migration patterns for households with and without children starting from year 1991, that is only one year before the reform, which is why it is hard to draw too much on the pre-reform moving patterns from the figures. Still, if Tiebout migration changes in response to the reform, it is likely that the moving pattern changes gradually, as there is evidence that the impact of the reform was also gradual (see Section 6.1). We therefore use the data at hand to test for changes over time in the moving patterns.

In particular, Table 18 shows the municipality average for the share of households that moved during the year, separately for each income group, and separately for households in which the oldest child was aged 0-3, 4-6 etcetera (see the table), and in which there were no children aged $0-17^{77}$. Moving is defined as either moving into the municipality or moving between parishes within the municipality. The first row of Table 18 shows the average of the yearly moving shares over years 1991-1995, while rows 3 and 5 show to which extent the average moving shares during years 1996-2000, and 2001-2005, differ from the 1991-1995-average.

While the share that moves varies a bit over time, there is no clear indication in that the households for whom Tiebout-migration can be expected to be relevant, i.e. those with children that are just about to start school (i.e. children aged 4-6), or children that have just started school (children aged 7-10) have changed their moving pattern after the choice-reform. In general, there is a slight negative trend in the moving shares among households with the oldest child aged 4-6 or 7-10, compared to households with no or old children, but the magnitudes are mostly very small. The table neither suggests that households with different income levels have changed their moving behaviour to different extent. These qualitative conclusions hold also if recent immigrants are

\footnotetext{
${ }^{77}$ This analysis was conducted on data that was generously made available from the Institute for Labour Market Policy Evaluation (IFAU). These data contain indicators for number of children living in the household, in the age spans $0-3,4-6,7-10,11-15$ and 16-17.
} 
excluded from the sample, or if we separately households based on the parents' education level. $^{78}$

Table 18: Share of households that moves between parishes during the year, divided into: different time periods, and for households with different disposable income, and with the oldest child in different age categories.

\begin{tabular}{|c|c|c|c|c|c|c|c|}
\hline Oldest child & age span: & $0-3$ & $4-6$ & $7-10$ & $11-15$ & $16-17$ & None $0-17$ \\
\hline \multirow{8}{*}{$\begin{array}{l}\text { below 25th } \\
\text { percentile }\end{array}$} & 1991-1995 & 0.203 & 0.147 & 0.122 & 0.106 & 0.107 & 0.148 \\
\hline & & $(0.002)$ & $(0.003)$ & $(0.003)$ & $(0.002)$ & $(0.003)$ & $(0.000)$ \\
\hline & 1996-2000: & & & & & & \\
\hline & 1991-1995 & 0.001 & 0.002 & $-0.010 * * *$ & -0.004 & -0.004 & $0.013^{* * *}$ \\
\hline & & $(0.003)$ & $(0.004)$ & $(0.004)$ & $(0.003)$ & $(0.005)$ & $(0.000)$ \\
\hline & 2001-2005: & & & & & & \\
\hline & $\begin{array}{l}\text { Difference vs. } \\
1991-1995\end{array}$ & 0.003 & -0.002 & $-0.013 * * *$ & -0.004 & -0.002 & $0.003 * * *$ \\
\hline & & $(0.003)$ & $(0.004)$ & $(0.004)$ & $(0.003)$ & $(0.004)$ & $(0.000)$ \\
\hline \multicolumn{2}{|l|}{ Obs } & 101,450 & 45,676 & 49,149 & 63,023 & 27,908 & $6,941,489$ \\
\hline \multirow{8}{*}{$\begin{array}{l}\text { 25th to } 75 \text { th } \\
\text { percentile }\end{array}$} & 1991-1995 & 0.163 & 0.119 & 0.082 & 0.061 & 0.063 & 0.102 \\
\hline & & $(0.001)$ & $(0.001)$ & $(0.001)$ & $(0.001)$ & $(0.001)$ & $(0.000)$ \\
\hline & $\begin{array}{l}\text { 1996-2000: } \\
\text { Difference vs. }\end{array}$ & & & & & & \\
\hline & 1991-1995 & $-0.004 * *$ & -0.002 & -0.001 & $0.005^{* * *}$ & $0.007 * * *$ & $0.005^{* * *}$ \\
\hline & & $(0.002)$ & $(0.001)$ & $(0.001)$ & $(0.001)$ & $(0.001)$ & $(0.000)$ \\
\hline & 2001-2005: & & & & & & \\
\hline & $\begin{array}{l}\text { Difference vs. } \\
\text { 1991-1995 }\end{array}$ & $0.004 *$ & $-0.009 * * *$ & $-0.009 * * *$ & -0.001 & $0.002 *$ & $0.003 * * *$ \\
\hline & & $(0.002)$ & $(0.002)$ & $(0.001)$ & $(0.001)$ & $(0.001)$ & $(0.000)$ \\
\hline \multicolumn{2}{|l|}{ Obs } & 215,840 & 274,946 & 451,263 & 684,827 & 314,002 & $12,879,735$ \\
\hline \multirow{7}{*}{$\begin{array}{l}\text { above 75th } \\
\text { percentile }\end{array}$} & 1991-1995 & 0.117 & 0.074 & 0.051 & 0.042 & 0.045 & 0.068 \\
\hline & & $(0.001)$ & $(0.001)$ & $(0.001)$ & $(0.000)$ & $(0.001)$ & $(0.000)$ \\
\hline & $\begin{array}{l}\text { 1996-2000: } \\
\text { Difference vs. } \\
\text { 1991-1995 }\end{array}$ & $0.007 * * *$ & -0.000 & 0.000 & $0.003 * * *$ & $0.006 * * *$ & $0.006 * * *$ \\
\hline & & $(0.002)$ & $(0.001)$ & $(0.001)$ & $(0.001)$ & $(0.001)$ & $(0.000)$ \\
\hline & 2001-2005: & & & & & & \\
\hline & $\begin{array}{l}\text { Difference vs. } \\
1991-1995\end{array}$ & $0.003 *$ & $-0.008 * * *$ & $-0.010 * * *$ & -0.001 & $0.004^{* * *}$ & $0.009 * * *$ \\
\hline & & $(0.002)$ & $(0.001)$ & $(0.001)$ & $(0.001)$ & $(0.001)$ & $(0.000)$ \\
\hline \multicolumn{2}{|l|}{ Obs } & 215,701 & 219,260 & 380,336 & 747,223 & 453,871 & $4,427,760$ \\
\hline
\end{tabular}

Robust standard errors in parentheses. Statistical significance at 1, 5 and $10 \%$ level is denoted by ***, **, *

${ }^{78}$ These tables are available upon request. 


\section{Additional tables for descriptive statistics or alternative specifications}

Table 19 shows the correlation between the measures for choice and competition that are used in Section 6.4, and Table 20 shows descriptive statistics for the covariates that are included in the regressions. All monetary variables have been deflated to year 2006 monetary value, using the consumer price index (source: Statistics Sweden, www.scb.se). The municipality level covariates were downloaded from the webpage of Statistics Sweden (www.scb.se), except for the indicator for urban municipality, which was constructed based on the 2005 year municipality classification by the Swedish Association of Local Authorities and regions (SKL). The parish level covariates were generated from individual level data generously made available from the Institute for Labour Market Policy Evaluation (IFAU). These data, as well as our individual level covariates, come from the national registers held by Statistics Sweden.

Table 21-Table 23 show additional summary statistics or results that are referred to in the paper.

Table 19: Correlation between competition and choice measure on grade level 7-9

Choice measures: Number of schools within radius...

\begin{tabular}{lll}
\hline & $\begin{array}{l}\text { Radius: median commuting } \\
\text { distance }\end{array}$ & Radius: $2 \mathrm{~km}$ \\
\hline $\begin{array}{l}\text { Competition Measures } \\
\begin{array}{l}\text { No. of schools, weighted by } \\
\text { distance and size of student } \\
\text { body }\end{array}\end{array}$ & 0.6898 & 0.5277 \\
$\begin{array}{l}\text { No. of schools within median } \\
\text { commuting distance }\end{array}$ & 0.9462 & 0.5016 \\
\begin{tabular}{l} 
No. of schools within 2km \\
\hline
\end{tabular} & 0.4482 & 0.7594 \\
\hline
\end{tabular}


Table 20: Descriptive statistics on covariates in the estimation

\begin{tabular}{|c|c|c|c|}
\hline & Mean & Std. Dev. & Median \\
\hline \multicolumn{4}{|l|}{ Municipality level variables } \\
\hline Population density & 392.35 & 876.36 & 64.00 \\
\hline Average taxable income in year t-2 in 100 SEK, deflated to 2006 & 1079.05 & 153.39 & 1067.89 \\
\hline Urban municipality & 0.54 & 0.50 & \\
\hline \multicolumn{4}{|l|}{ Parish level variables } \\
\hline Share of $16-64$ year olds born in Sweden & 0.89 & 0.08 & 0.92 \\
\hline Average yearly earnings of $20-64$ year olds in 100 SEK & 1140.46 & 224.25 & 1150.94 \\
\hline Share of $20-64$ year olds with university degree & 0.20 & 0.09 & 0.18 \\
\hline Share of $20-64$ year olds that are employed & 0.83 & 0.04 & 0.84 \\
\hline $\begin{array}{l}\text { Population density of } 7-15 \text { year olds in lower quartile of } \\
\text { distribution }\end{array}$ & 0.09 & 0.28 & \\
\hline $\begin{array}{l}\text { Population density of 7-15 year olds in highest quartile of } \\
\text { distribution }\end{array}$ & 0.64 & 0.48 & \\
\hline \multicolumn{4}{|l|}{ Individual level variables } \\
\hline Household income in 1000 SEK, deflated to 2006 & 373.77 & 382.38 & 350.00 \\
\hline Household received welfare & 0.06 & 0.24 & \\
\hline Age of mother at birth & 27.78 & 5.05 & 27.00 \\
\hline Single parent household & 0.22 & 0.42 & \\
\hline Number of children & 2.23 & 1.01 & 2.00 \\
\hline Only child & 0.23 & 0.42 & \\
\hline Child born in Sweden & 0.96 & 0.19 & \\
\hline Mother born in Sweden & 0.89 & 0.32 & \\
\hline Mother born in Scandinavia, outside of Sweden & 0.05 & 0.21 & \\
\hline Mother born in western Europe, North America or Australia & 0.01 & 0.10 & \\
\hline Father born in Sweden & 0.88 & 0.32 & \\
\hline Father born in Scandinavia, outside of Sweden & 0.04 & 0.19 & \\
\hline Father born in western Europe, North America or Australia & 0.02 & 0.13 & \\
\hline Mother has university degree & 0.31 & 0.46 & \\
\hline Mother's highest degree is from secondary education & 0.49 & 0.50 & \\
\hline Father has university degree & 0.27 & 0.44 & \\
\hline Father's highest degree is from secondary education & 0.46 & 0.50 & \\
\hline Number of observations: 1756681 & & & \\
\hline
\end{tabular}


Table 21: Descriptive statistics for the within-municipality standard deviation for pre-reform choice measures

\begin{tabular}{|c|c|c|c|c|c|c|c|c|}
\hline & \multicolumn{4}{|c|}{$\begin{array}{l}\text { Pre-reform cohorts } \\
\text { (cohorts 1972-1976 are not affected) }\end{array}$} & \multicolumn{4}{|c|}{$\begin{array}{l}\text { Post-reform cohorts } \\
\text { (cohorts 1977-1990 are affected) }\end{array}$} \\
\hline & Mean & $\begin{array}{l}\text { Std. } \\
\text { Dev. }\end{array}$ & Median & Obs. & Mean & $\begin{array}{l}\text { Std. } \\
\text { Dev. }\end{array}$ & Median & Obs. \\
\hline \multicolumn{9}{|c|}{$\begin{array}{l}\text { Number of schools within median } \\
\text { commuting distance }\end{array}$} \\
\hline All municipalities & 3.43 & 4.05 & 1.57 & 449802 & 3.39 & 3.96 & 1.57 & 1306879 \\
\hline Urban municipalities & 5.58 & 4.46 & 4.58 & 244087 & 5.49 & 4.34 & 4.58 & 713007 \\
\hline Non-urban municipalities & 0.88 & 0.50 & 0.81 & 205715 & 0.87 & 0.50 & 0.80 & 593872 \\
\hline \multicolumn{9}{|c|}{ Number of schools within $2 \mathrm{~km}$} \\
\hline All municipalities & 1.04 & 0.57 & 0.89 & 449802 & 1.06 & 0.59 & 0.90 & 1306879 \\
\hline Urban municipalities & 1.31 & 0.59 & 1.16 & 244087 & 1.35 & 0.60 & 1.18 & 713007 \\
\hline Non-urban municipalities & 0.71 & 0.31 & 0.61 & 205715 & 0.70 & 0.31 & 0.60 & 593872 \\
\hline
\end{tabular}

Note: The table displays pre-reform measures on grade level 7-9. Sample contains only observations with full information on all covariates $\mathrm{X}$ given below Table 3. The summary statistics in the table are calculated based on the individual level data.

Table 22: Results when individual-, parish- and municipality covariates are omitted from the regression. (Cohort and municipality fixed remain included).

Choice Measure: Number of schools in median commuting distance Grade Level: 7-9

\begin{tabular}{|c|c|c|c|c|c|c|}
\hline & $\begin{array}{l}\text { Percentile } \\
\text { rank } \\
\text { grade } 9\end{array}$ & $\begin{array}{l}\text { Cognitive } \\
\text { draft score } \\
\text { (Men only) }\end{array}$ & $\begin{array}{l}\text { University } \\
\text { degree } \\
\text { at age } 25^{\dagger}\end{array}$ & $\begin{array}{l}\text { Employed } \\
\text { age } 25\end{array}$ & $\begin{array}{c}\text { Any crime } \\
\text { until age } 22\end{array}$ & $\begin{array}{l}\text { Health } \\
\text { age } 22\end{array}$ \\
\hline $\begin{array}{l}\text { Cohorts } 1988-1990 \\
\text { rel. to untreated }\end{array}$ & $\begin{array}{l}0.196 * * * \\
(0.0238)\end{array}$ & & & & & \\
\hline $\begin{array}{l}\text { Cohorts } 1985-1987 \\
\text { rel. to untreated }\end{array}$ & $\begin{array}{l}0.140 * * * \\
(0.0244)\end{array}$ & $\begin{array}{l}-0.000280 \\
(0.00188)\end{array}$ & & & $\begin{array}{c}-0.00140 * * * \\
(0.000183)\end{array}$ & $\begin{array}{l}0.000217 * \\
(0.000117)\end{array}$ \\
\hline $\begin{array}{l}\text { Cohorts } 1982-1984 \\
\text { rel. to untreated }\end{array}$ & $\begin{array}{c}0.0783^{* * *} \\
(0.0237)\end{array}$ & $\begin{array}{l}-0.000980 \\
(0.00191)\end{array}$ & $\begin{array}{l}0.000820 * * \\
(0.000373)\end{array}$ & $\begin{array}{c}0.00131 * * * \\
(0.000256)\end{array}$ & $\begin{array}{c}-0.00152 * * * \\
(0.000187)\end{array}$ & $\begin{array}{c}6.04 \mathrm{e}-05 \\
(0.000119)\end{array}$ \\
\hline $\begin{array}{l}\text { Cohorts } 1979-1981 \\
\text { rel. to untreated }\end{array}$ & $\begin{array}{c}0.0828 * * * \\
(0.0259)\end{array}$ & $\begin{array}{l}-0.000999 \\
(0.00205)\end{array}$ & $\begin{array}{c}9.45 e-05 \\
(0.000413)\end{array}$ & $\begin{array}{c}0.000417 \\
(0.000296)\end{array}$ & $\begin{array}{c}-0.00116 * * * \\
(0.000210)\end{array}$ & $\begin{array}{c}8.31 \mathrm{e}-05 \\
(0.000133)\end{array}$ \\
\hline $\begin{array}{l}\text { Cohorts } 1977-1978 \\
\text { rel. to untreated }\end{array}$ & $\begin{array}{c}0.0438 \\
(0.0357)\end{array}$ & $\begin{array}{c}0.00226 \\
(0.00313)\end{array}$ & $\begin{array}{l}-5.71 e-05 \\
(0.000584)\end{array}$ & $\begin{array}{c}-0.00177 * * * \\
(0.000398)\end{array}$ & $\begin{array}{l}-2.83 e-07 \\
(0.000321)\end{array}$ & $\begin{array}{c}9.21 \mathrm{e}-05 \\
(0.000173)\end{array}$ \\
\hline $\begin{array}{l}\text { Untreated Cohorts } \\
(1972-1976)\end{array}$ & $\begin{array}{c}-0.0431 * * \\
(0.0217)\end{array}$ & $\begin{array}{l}0.00403 * * \\
(0.00188)\end{array}$ & $\begin{array}{l}0.00140 * * * \\
(0.000368)\end{array}$ & $\begin{array}{c}-0.00361^{* * *} \\
(0.000259)\end{array}$ & $\begin{array}{l}0.00183^{* * * *} \\
(0.000190)\end{array}$ & $\begin{array}{c}- \\
0.000440 * * * \\
(0.000122)\end{array}$ \\
\hline Observations & $1,821,110$ & 645,730 & $1,195,838$ & $1,196,364$ & $1,500,869$ & 1,493,822 \\
\hline R-squared ${ }^{\ddagger}$ & 0.016 & 0.017 & 0.0159 & 0.0096 & 0.0059 & 0.0092 \\
\hline
\end{tabular}

Notes: Robust standard errors in parentheses. Statistical significance at 1,5 and $10 \%$ level is denoted by ***, **, *. The definition of the placebo tests is explained in Section 5. The mean of the cognitive score is 5, the standard deviation 1.9.

† For the outcome university degree at age 25, we had to leave out household income and its squared term to achieve convergence. The results are qualitatively the same when leaving the variables in and stopping the estimation after 25 iterations, and when comparing OLS results including the variables to those that do not. $\ddagger$ Pseudo R-squared for binary outcomes. 
Table 23: Results for Percentile Rank Grade 9 for different samples

Choice Measure: Number of schools in median commuting distance

Grade Level: 7-9

\begin{tabular}{lcccc}
\hline & \multicolumn{4}{c}{ Percentile rank grade 9} \\
& All & Females & Males & Draftees \\
\hline Cohorts 1988-1990 rel. to untreated & $0.130^{* * *}$ & $0.190^{* * *}$ & $0.0763^{* * *}$ & \\
& $(0.0183)$ & $(0.0223)$ & $(0.0241)$ & \\
Cohorts 1985-1987 rel. to untreated & $0.0772^{* * *}$ & $0.122^{* * *}$ & 0.0386 & 0.00491 \\
& $(0.0186)$ & $(0.0228)$ & $(0.0241)$ & $(0.0245)$ \\
Cohorts 1982-1984 rel. to untreated & 0.0100 & $0.0682^{* * *}$ & $-0.0417^{*}$ & $-0.0721^{* * *}$ \\
& $(0.0183)$ & $(0.0231)$ & $(0.0238)$ & $(0.0239)$ \\
Cohorts 1979-1981 rel. to untreated & 0.0231 & $0.0895^{* * *}$ & -0.0295 & $-0.0481^{*}$ \\
& $(0.0195)$ & $(0.0249)$ & $(0.0254)$ & $(0.0253)$ \\
Cohorts 1977-1978 rel. to untreated & -0.0139 & 0.00772 & -0.0392 & -0.0312 \\
& $(0.0227)$ & $(0.0293)$ & $(0.0308)$ & $(0.0305)$ \\
\hline \multirow{2}{*}{ Untreated Cohorts (1972-1976) } & $-0.0334^{*}$ & $-0.0886^{* * *}$ & 0.0132 & $0.0414^{*}$ \\
& $(0.0173)$ & $(0.0218)$ & $(0.0231)$ & $(0.0232)$ \\
Observations & & & & \\
R-squared & $1,715,421$ & 835,696 & 879,725 & 607,086 \\
\hline Robust stan & 0.186 & 0.193 & 0.200 & 0.193 \\
\hline
\end{tabular}

Robust standard errors in parentheses.

$* * * \mathrm{p}<0.01, * * \mathrm{p}<0.05, * \mathrm{p}<0.1$

\section{Grade Inflation}

It is a major concern that grades have been inflated since competition between schools has increased. If parents care about grades, schools have an incentive to give slightly better grades in order to attract more students. The grade point average at the end of $9^{\text {th }}$ grade determines admission into upper secondary schools in Sweden and will thus be an important and observable scholastic output for parents. In addition, standardized national tests, which can be used by teachers as a check for the grade levels, were not mandatory for schools to use during most of the years that we study. The schools' need to be attractive for students should be larger in areas with a lot of competition, such that any potential positive effects of more competition on marks cannot easily be disentangled from grade inflation.

How serious is this concern in the Swedish case? Wikström and Wikström (2005), who compare the final grades from upper secondary school in 1997 to the SweSAT national test scores, find no evidence that competition from private schools, as measured on the municipality level, leads to grade inflation. However, they find that the difference between a standardised test and grades at the end of upper secondary school is much larger in independent schools. Vlachos (2010), who uses data on grades and 
national standardized test scores, finds no indication of different rates of grade inflation between private and public schools overall, but finds some evidence of higher grade inflation in private for-profit schools.

The potential link between school competition and grade inflation should still be taken seriously, and in this study we have addressed this by considering also outcomes determined outside of the school, like the cognitive score in the military test and labour market outcomes. However, it could still be that inflated grades permit admission to better high schools which in turn also improves these "real" outcomes. For that reason, we provide another robustness check by using data on student grades from mandatory standardized national tests in English, Swedish and Math, taken at the end of grade 9, that we have available for the years 2003-2008 ${ }^{79}$. We use these data to test if our school choice measures can predict grades even when we control for the test results, something which would indicate that grade inflation is present. However, it is to be kept in mind that this approach has a potential pitfall: if grades measure something different than just performance in tests, then any additional explanatory power of school choice over and above tests could result from choice positively affecting other skills that are necessary to obtain a good grade. ${ }^{80}$

Since we are interested in whether effects that we capture with our measures of choice and competition are driven by grade inflation, we use the exactly same measures as in the main estimations to test for grade inflation here. As we only observe the test scores for $9^{\text {th }}$ graders in the years 2003-2008, we only use cohorts from our sample that were 16 in these years, i.e. cohorts 1987-1990. We start by estimating Equation (7) separately for the grade in each subject $i$, Math, English and Swedish. Since the subject specific grades are given on an ordinal 1-4 scale (no pass, pass, pass with distinction and pass with special distinction) we estimate an ordinal probit regression for the four grade levels. As test grade regressors we use dummy variables for the three levels of pass-grades, denoted test $t_{k}$ in the regression equation, and let "no pass" be the reference

\footnotetext{
${ }^{79}$ Previously, these tests were voluntary for the schools, and are not centrally available, which is why we cannot use them for all cohorts.

${ }^{80}$ In Sweden, teachers form grades by assessing the class room performance of students. Non-cognitive skills, such as pro-social behaviour, patience and the ability to control ones temperament, might be of higher importance in receiving a good grade in the class room than in performing well in a standardized test.
} 
category. In addition the regression includes all covariates included in the main estimations, except for the municipality dummies ${ }^{81}$.

$$
\text { grade }_{i}=\alpha \cdot c_{i}+\beta_{k} \cdot \text { test }_{i k}+\gamma_{\text {cohort }}+\delta \cdot X_{i}+u_{i}
$$

where $c_{i}$ refers to the pre-reform choice measure.

Table 24 shows the resulting average marginal effects. They show that our measure of school choice is positively correlated with the grade received even after controlling for the respective test result, even though the marginal effects are very small. This indicates that there is potentially higher grade inflation in areas with higher levels of school choice. However, as the grades in the subject have another scale than the percentile rank in GPA in grade 9, it is hard to assess whether this can account for the complete effect that we found in Section 6.

Table 24: Grade inflation, regressions for different subjects

Outcome: Grade in subject

Grade Level: 7-9

\begin{tabular}{lcccccc}
\hline & \multicolumn{3}{c}{ No. schools within median } & \multicolumn{3}{c}{ No. schools within $2 \mathrm{~km}$} \\
\cline { 2 - 7 } Grade: & Math & English & Swedish & Math & English & Swedish \\
\cline { 2 - 7 } Test in respective & $0.614^{* * *}$ & $0.816^{* * *}$ & $0.742^{* * *}$ & $0.614^{* * *}$ & $0.816^{* * *}$ & $0.742^{* * *}$ \\
subject: & $(0.00240)$ & $(0.00270)$ & $(0.00328)$ & $(0.00240)$ & $(0.00270)$ & $(0.00328)$ \\
Choice & 0.00257 & 0.00264 & $0.00505^{* * *}$ & 0.00783 & $0.0241^{* * *}$ & $0.0219^{* * *}$ \\
Observations & $(0.00156)$ & $(0.00167)$ & $(0.00176)$ & $(0.00538)$ & $(0.00558)$ & $(0.00649)$ \\
R-squared & 332,001 & 194,647 & 189,725 & 332,001 & 194,647 & 189,725 \\
\hline Notes: Robust standard errors in parentheses. Statistical significance at 1,5 and $10 \%$ level is denoted by *******
\end{tabular}

Notes: Robust standard errors in parentheses. Statistical significance at 1,5 and $10 \%$ level is denoted by ***, **, *. For a complete list of included covariates see Table 3.

The outcome variable "Grade in subject " as well as the variables "Test in respective Subject" are defined as the credit value corresponding to each grade level: No pass $=0$ credits, Pass $=10$ credits, Pass with distinction $=15$ credits and Pass with special distinction $=20$ credits.

In order to shed some light on this, we also estimate Equation (8), using the percentile rank in GPA in grade 9 as outcome and controlling for all three test results that we have information on (Swedish, English, math) at the same time. The test grades are included as dummies for each of the $k$ pass-categories, as in the test specific regression above.

\footnotetext{
${ }^{81}$ Adding the municipality dummies caused convergence problems for the ordered probit regressions, which is why they were dropped.
} 
We include the same covariates as we did in the main estimation, including the municipality dummies, and our choice measure.

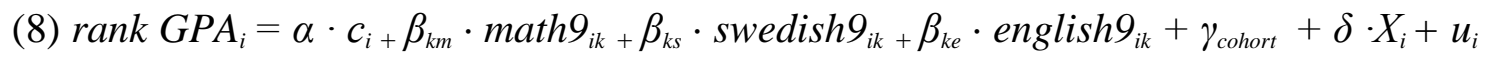

where rank GPA refers to the percentile rank of GPA at the end of $9^{\text {th }}$ grade. The idea is that even though these test results only account for some of the grades that make up the grade point average, finding no effects of our choice-measure when we include them could be seen as an indication that grade inflation is probably not correlated with our choice-measure. Table 25 shows the results for the choice measures counting the number of schools within the median commuting distance and $2 \mathrm{~km}$ around a student's home in columns one and two respectively. We find small statistically significant effects of choice on the grades. ${ }^{82}$ However, the coefficients are smaller than the marginal effects from our baseline estimation in Section 6.1. We can thus conclude that, even if there is some grade inflation related to having more schools to choose from, its effect on our estimates is probably small.

\footnotetext{
${ }^{82}$ Note, for the interpretation of the coefficients, that student test score grades are measured at an ordinal 1-4 scale, while our dependent variable for $9^{\text {th }}$ grade GPA is in terms of percentile rank.
} 
Table 25: Grade inflation

Outcome: Percentile rank GPA 9

Choice Measure: Number of schools within radius...

Grade Level: $7-9$

\begin{tabular}{|c|c|c|}
\hline & $\begin{array}{l}\text { Radius: median commuting } \\
\text { distance }\end{array}$ & Radius: $2 \mathrm{~km}$ \\
\hline \multicolumn{3}{|l|}{ Math: } \\
\hline Pass & $\begin{array}{c}11.17 * * * \\
(0.152)\end{array}$ & $\begin{array}{c}11.17 * * * \\
(0.152)\end{array}$ \\
\hline Pass with distinction & $\begin{array}{c}27.20 * * * \\
(0.189)\end{array}$ & $\begin{array}{c}27.20 * * * \\
(0.189)\end{array}$ \\
\hline Pass with special distinction & $\begin{array}{l}35.31 * * * \\
(0.208)\end{array}$ & $\begin{array}{c}35.31^{* * *} \\
(0.208)\end{array}$ \\
\hline \multicolumn{3}{|l|}{ English: } \\
\hline Pass & $\begin{array}{c}6.297 * * * \\
(0.210)\end{array}$ & $\begin{array}{c}6.299 * * * \\
(0.210)\end{array}$ \\
\hline Pass with distinction & $\begin{array}{l}12.18 * * * \\
(0.236)\end{array}$ & $\begin{array}{c}12.18 * * * \\
(0.236)\end{array}$ \\
\hline Pass with special distinction & $\begin{array}{c}16.34 * * * \\
(0.263)\end{array}$ & $\begin{array}{c}16.34^{* * *} \\
(0.263)\end{array}$ \\
\hline \multicolumn{3}{|l|}{ Swedish: } \\
\hline Pass & $\begin{array}{c}8.577 * * * \\
(0.214)\end{array}$ & $\begin{array}{c}8.575 * * * \\
(0.214)\end{array}$ \\
\hline Pass with distinction & $\begin{array}{c}25.92 * * * \\
(0.257)\end{array}$ & $\begin{array}{c}25.91 * * * \\
(0.257)\end{array}$ \\
\hline Pass with special distinction & $\begin{array}{c}36.25 * * * \\
(0.289)\end{array}$ & $\begin{array}{c}36.25 * * * \\
(0.289)\end{array}$ \\
\hline Choice & $\begin{array}{l}0.0320 * * \\
(0.0126)\end{array}$ & $\begin{array}{l}0.0737^{*} \\
(0.0433)\end{array}$ \\
\hline Constant & $\begin{array}{c}213.3^{* *} \\
(102.8)\end{array}$ & $\begin{array}{c}214.0^{* *} \\
(102.9)\end{array}$ \\
\hline Observations & 173,284 & 173,284 \\
\hline R-squared & 0.666 & 0.666 \\
\hline
\end{tabular}

\section{The military score}

As mentioned in Section 4, the share of men going through the drafting process declined significantly starting from the late 1990s. This means that for the younger cohorts in our sample, no longer all Swedish men took part in the military test. Figure 2 shows that the share of men not taking part in the draft test rose from around 7 percent for the cohort born in 1972 to around 43 percent for cohort 1987. The sharp increase started with men born in the years 1980 and 1981. 
Figure 2: Share of men in each cohort for which we do not observe the military test

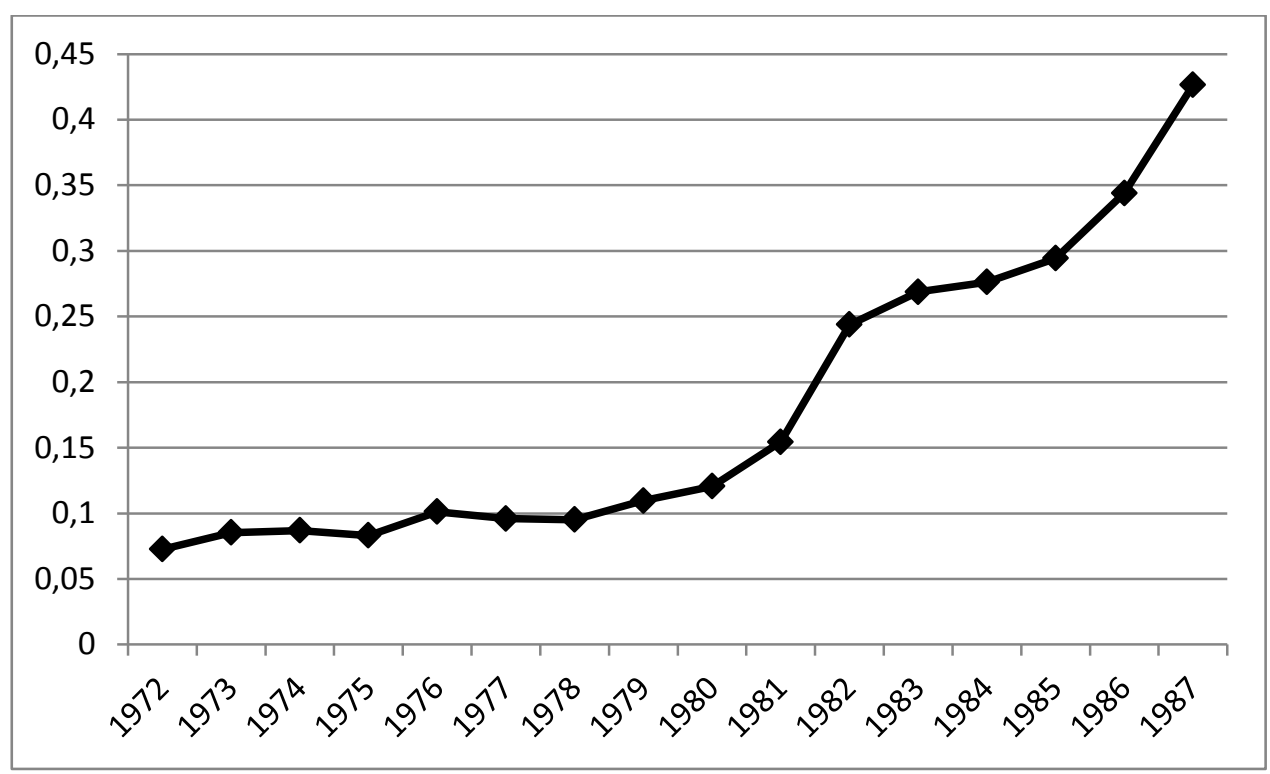

This raises concerns about potential selection into taking the test and being ready to possibly serve in the military. In order to test whether such selection is likely to bias our results, we run our treatment effect analysis with the same covariates we use for the main estimations on the outcome "not taking part in the test". Results of this analysis are presented in Table 26.

Table 26: Selection into taking the military test

Outcome: Not taking the military test

Choice measure: Number of schools within radius.

Grade Level: 7-9

Radius: median commuting distance

Radius: 2 km

\begin{tabular}{lcc}
\hline Cohorts 1985-1987 rel. to untreated & $-0.00440^{* * *}$ & $-0.00651^{* * *}$ \\
& $(0.000239)$ & $(0.00103)$ \\
Cohorts 1982-1984 rel. to untreated & $-0.00381^{* * *}$ & $-0.00619^{* * *}$ \\
& $(0.000226)$ & $(0.00110)$ \\
Cohorts 1979-1981 rel. to untreated & $-0.00178^{* * *}$ & $0.00138^{*}$ \\
& $(0.000210)$ & $(0.000742)$ \\
Cohorts 1977-1978 rel. to untreated & $-0.000639^{* * *}$ & 0.000904 \\
& $(0.000247)$ & $(0.000777)$ \\
\hline Untreated Cohorts (=1972-1976) & $0.00186^{* * *}$ & $0.00286^{* * *}$ \\
& $(0.000175)$ & $(0.000411)$ \\
Placebo test & Pass & Fail \\
Specification & Treatment windows & 723,147 \\
Observations & 723,147 & 0.134 \\
Pseudo R-squared & 0.134 & Treatment windows \\
\hline
\end{tabular}

Notes: Robust standard errors in parentheses. Statistical significance at 1, 5 and $10 \%$ level is denoted by ${ }^{* * *},{ }^{* *},{ }^{*}$. For a complete list of included covariates see Table 3. 
We find that having one more school offering grade 7-9 within the median commuting distance of a student's place of residence in or before 1991 decreases the probability to miss the test by 0.44 percentage points for the cohorts that are most affected by the reform. We find similar results using the number of schools within a $2 \mathrm{~km}$ radius, however, the placebo-test fails for this specification. Even though this effect is mostly statistically significant, it is relatively small compared to the share of men not taking part in the test in these youngest cohorts, which is 30 to 43 percent. We thus do not believe that our results on the cognitive skills test score are biased in a quantitatively relevant way. 